\title{
Diversity of boreal small species of Cortinarius subgenus Telamonia with Salix
}

\section{Katri Kokkonen ${ }^{1}$}

\section{Mahalanniementie 150, 75700 Valtimo, Finland Herbarium, Biodiversity Unit, University of Turku, 20014 Turku, Finland katkok@utu.fi}

Key words: Taxonomy - Molecular systematics . Biogeography · Fennoscandia - Agaricales

\section{Article info:}

Received: 19 February 2020

Accepted: 18 May 2020

Published online: 1 September 2020

Corresponding Editor: Riikka Linnakoski

Electronic supplementary materials:

Table 1

Sequence alignments

\section{Abstract}

This work presents the genetic and morphological diversity of small Cortinarius subgenus Telamonia species found from moist Salix thickets in Finland. The boreal fungi were compared with several type and other specimens from the alpine zone or similar habitats from the temperate zone. The boreal and alpine zones had many common species: nearly all boreal species grew in the alpine zone with dwarf Salix. The species often had wide distributions, extending to North America. The genetic analyses consisted of ITS and RPB2 sequences. Both genetic and morphological variation was high. The species formed complexes, where the boundaries among species were often obscure. Very close sibling species were delimited based on differences at the same sites. Twenty-three boreal species were recognized. Four of them are described here as new: $C$. paulus and $C$. paululus as sibling species to $C$. pauperculus J.Favre, C. rusticelloides as a sibling species to C. rusticellus J.Favre, and $C$. vienoi as a sibling species to C. perzonatus Reumaux. Cortinarius sagarum, a sibling species to C. comatus J.Favre and C. vulpicolor M.M.Moser \& McKnight, is described as new from arctic-alpine zones. 


\section{Introduction}

Boreal Salix thickets have a rich mycoflora of agarics (Agaricales), and the most species-rich genus there is Cortinarius. Nearly all these species are small and belong to subgenus Telamonia sections Hydrocybe (Fr.) Nezdojm. and Incrustati Melot. Owing to the difficulties in identifying them, the purpose of this study was to clarify the number and characters of these species as well as to name them. Cortinarius is a very large genus that has been extensively studied in Europe, but its taxonomy is far from complete. Recently developed molecular methods have promoted the Cortinarius taxonomy, especially concerning boreal forest species (e.g. Niskanen et al. 2009, 2011, 2013, 2016, Liimatainen et al. 2014, 2015, 2017, Dima et al. 2016, Brandrud et al. 2018). This study focused on a specific habitat, alluvial Salix thickets. Surveys concerning the diversity of Telamonia associated with boreal Salix have not been published before. This study was mostly conducted in Finland, where Salix thickets occur commonly along lakes and rivers. The Cortinarius species in Salix thickets seemed to differ from forest species. Since most Telamonia species associated with Salix have been described from alpine habitats (Favre 1948, 1955, Lamoure 1977, 1978, Moser \& McKnight 1987, Moser 1993), the comparison with alpine species was essential.

The use of the ITS (internal transcribed spacer) region has generally been sufficient for the identification of Cortinarius species, but the interspecific differences have been scantier when compared with many other fungal genera (e.g. Frøslev et al. 2007, Peintner 2008, Niskanen et al. 2011, 2013). Since the ITS differences among species often appeared few also in this study, another region, RPB2 (RNA polymerase II subunit), was analysed in several species complexes to help recognize species limits. The RPB2 region has sometimes been used successfully together with the ITS region to delimit Cortinarius species (Frøslev et al. 2005). Whether the few genetic or morphological differences are intraspecific or interspecific depends also on the interpretation. The interpretation was grounded on site-specific comparisons in this study. The observed diversity is presented here as a whole including yet unidentified species and specimens. The results, which include several sequenced type specimens and five new species, contribute to the knowledge of boreal and arctic-alpine Cortinarius species.

\section{Materials and Methods}

\section{Specimen sampling}

The species descriptions are largely based on the author's own collections. The study concentrated on Salix habitats of eastern and northern Finland. Most specimens were collected from the municipalities of Nurmes and Valtimo in North Karelia. The district is in the transition zone between the southern and middle boreal zones. Many specimens originated also from the northern boreal and alpine zones. $\mathrm{Al}-$ pine fungi were collected from some fjelds or mountains of Finland, Iceland, Norway, Sweden, and Switzerland. In addition to inland habitats, specimens were collected from seashores in the middle boreal zone of Finland. The North Karelian sites were visited many times during some years. All photos were taken by the author excluding a C. comatus photo of Emanuele Campo.

The boreal inland study sites were alluvial Salix thickets or shore forests with Salix bushes by lakes and rivers. Only few Telamonia were collected from other habitats, like swamps or ditches. Salix phylicifolia was the main tree species, mixed usually with S. myrsinifolia, or S. lapponum in Lapland, and occasional other Salix species. Some Telamonia grew with $S$. repens on seashore. The exceptional and arctic-alpine Salix species are mentioned with the descriptions. The soil of the boreal sites varied from muddy to sand. All North Karelian sites had a mesotrophic - eutrophic, muddy, often paludified soil. The fungi grew among hygrophilous mosses, among leaf litter, or rarely on bare soil. Tree species and other vegetation were noted at the collections sites. All specimens are deposited in TUR, unless otherwise stated.

Herbarium specimens were examined especially from TUR and TUR-A. Types or other specimens were also examined from G, described by J. Favre, 
from IB, described by M. Moser and K. McKnight, from LY, described by D. Lamoure, from PC, described or collected by A. Bidaud, X. Carteret, H. Romagnesi, P.-A. Moreau and P. Reumaux, from REG, determined by N. Arnold, from private herbaria of A. Bidaud and P. Moënne-Loccoz, and from S, the type of Cortinarius vernus H.Lindstr. \& Melot.

The examined Telamonia species had pilei under ca. $50 \mathrm{~mm}$ in diameter and stipes under ca. 5 mm wide. Larger Telamonia like C. saturninus (Fr.: Fr.) Fr. occurred rarely in the Salix thickets, and were excluded from this study. The taxonomy of sect. Saturnini has been published by Liimatainen et al. (2017).

\section{Morphological studies}

The macroscopic descriptions were based on fresh fruitbodies, unless otherwise stated. The colour codes of fresh fungi refer to Küppers (1999). The stipe width was measured at the widest point.

Microscopic features were examined from dried material at $\times 1,000$ magnification. Spores and lamellar hyphae were examined in Melzer's reagent. Only mature spores from lamellae were considered. The number of measured spores per specimen was twenty for the types or the new species and ten for other specimens, unless otherwise stated. Spore measures excluded verrucae, and basidial lengths excluded sterigmata. The sizes of structures are given as length $\times$ width. The interval is the range with the mean underlined. The $Q$ value means the ratio of spore length to spore width (calculated for each spore). Pileipellis has not been regarded as useful for the identifications of closely related Telamonia species, since they have often had very similar cap cuticle structures (Niskanen 2008). However, pileipelles of the new species were examined in $10 \% \mathrm{NH}_{4} \mathrm{OH}$.

\section{Molecular methods}

Molecular methods included the ITS region with 5.8S rDNA as the most important sequence. The RPB2 sequences were analysed in some of the most difficult species complexes to compare with the ITS result. All type sequences, high-quality sequences showing intraspecific divergence, and some additional sequences, especially from different countries, were submitted to GenBank and two sequences to ENA (European Nucleotide Archive). The accession numbers are listed in Table 1 (Electronic Supplementary Material 1). All sequenced specimens have been marked with an asterisk $(*)$ in the respective descriptions. The extraction method followed Kokkonen \& Vauras (2012) except that both NucleoSpin Tissue XS and Plant II kits (Macherey-Nagel) were used. The PCR primers for the ITS region were ITS1-F, ITS4-B (Gardes \& Bruns 1993), ITS2 and ITS3 (White et al. 1990) with a few exceptions. In case the primers mentioned before did not work, the primer pair ITS5 (White et al. 1990) and ITS2 was used for the ITS1 region, and one of the two new forward primers, fITS7tel or ITStel1, was used with ITS4 (White et al. 1990) for the ITS2 region. The primer fITS7tel (5'-GTGAATCATCGAATCTTTG-3') was modified from fITS7 primer (Ihrmark et al. 2012), and the sequence of ITStell was 5'-GAGCATGCCTGTTTGAGTG-3'. The ITS sequencing primers were ITS1 (White et al. 1990), ITS2, ITS3, fITS7tel, ITStel1, and ITS4. The RPB2 primers for PCR and sequencing were RPB2-6F and RPB2-7R (Liu et al. 2000). The PCR was run using a GeneAmp PCR system 9700 (PE Applied Biosystems), with Pure Taq Ready-ToGo PCR beads (GE Healthcare). The reaction volume $25 \mu \mathrm{l}$ composed of $4 \mu \mathrm{l}$ extract, $1 \mu \mathrm{l}$ primers and $19 \mu \mathrm{l}$ water. The PCR procedure consisted of 5 min at 94 ${ }^{\circ} \mathrm{C}, 30-40$ cycles of $1 \mathrm{~min}$ at $94{ }^{\circ} \mathrm{C}, 1 \mathrm{~min}$ at $51-56{ }^{\circ} \mathrm{C}$, and $1 \mathrm{~min}$ at $72{ }^{\circ} \mathrm{C}$, and then a final extension step of $7 \mathrm{~min}$ at $72{ }^{\circ} \mathrm{C}$. PCR products were purified with the Ezna Cycle Pure kit (Omega), or the service provided by Macrogen. All samples were sequenced by Macrogen. The sequences were edited with Seqman (DNAStar), and the fasta files were aligned for comparisons using Clustalw (www.genome.jp). Positions with ambiguous bases and missing data in the conservative middle part of the ITS region were usually excluded from the comparisons.

\section{Phylogenetic methods}

For the ITS and RPB2 phylogenetic analyses, the sequences were aligned using MAFFT 7.0 (Katoh 2013) and adjusted manually in AliView (Larsson 2014). Ambiguously aligned regions were kept. The RPB2 sequences were aligned according to the codons. The alignments are in Electronic Supplementary Materials 2 and 3. The phylogenetic trees were performed by maximum likelihood (ML) analysis in raxmlGUI 2.0 (Stamatakis 2014, Edler et al. 2019) 
with thorough bootstrap and GTRGAMMA model. The number of autoMRE bootstrap replicates was 500 for ITS and 950 for RPB2. The RPB2 analysis included a codon specific partition. The analyses were repeated including informative gaps coded as binary data. The gaps were coded by FastGap 1.2 (Borchsenius 2009). The resulting trees were similar, but since the influence of coded gaps was regarded as too strong among very close ITS sequences, the trees with uncoded gaps were selected. The concatenated analysis of ITS and RPB2 alignments was run for sequences of common specimens. The model was GTRCAT. The tree did not provide significant new information and is not presented. The trees were edited in MEGA X (Kumar et al. 2018) and GIMP 2.8. The Bayesian analysis was performed with MrBayes 3.2.6 (Ronquist and Huelsenbeck 2003) with GTR + I + 「 model, burninfrac 0.25, samplefreq 500 , printfreq 500 and diagnfreq 1000. The number of generations was 2320000 for ITS and 680000 for RPB2. The phylogenetic analyses included sequences from public databases. Cortinarius violaceus sequences from GenBank (Harrower et al. 2015) were used as outgroups.

\section{Results}

\section{CORTINARIUS CASIMIRI COMPLEX}

Fungi resembling C. casimiri (Velen.) Huijsman occur rather commonly in boreal Salix thickets. They can be recognized by the large ellipsoid spores and stipe with a pale fibrillose cover. Their spore shape and size varied to some extent, but fungi from Salix habitats had usually somewhat smaller and more subamygdaloid spores compared with the casimiri collections from other habitats. These fungi were identified as $C$. rufostriatus J.Favre based on the type study. Since they deviated from the casimiri group only by 2 bases and 2 indels in ITS, they may be included in the variation of $C$. casimiri, but due to the observed slight morphological and possible host differences, as well as by a distinct 8 base RPB2 sequence difference, they are considered here as a sep- arate species. Contrary to the rufostriatus group, the casimiri group was never observed with dwarf Salix in the alpine zone or in boreal pure Salix thickets, but always at least Betula grew nearby.

\section{Cortinarius rufostriatus J.Favre, Ergebn.} Wiss. Unters. Schweiz. Natl. Parks 5 (33): 204 (1955)

Synonym Cortinarius hemitrichoides Bidaud \& Moënne-Locc., Atlas des Cortinaires 19: 1506 (2010)

Figure 1

Cortinarius rufostriatus was described from the Swiss Alps growing with Salix herbacea (Favre 1955). Horak (1987) divided the type fruitbodies into two parts according to the spore morphology and regarded the type as a mixed specimen. By morphology and ITS analysis, both parts are regarded here to belong to the variation of $C$. rufostriatus. Their ITS sequences deviated one base and an indel from each other, but both grouped distinctly together with the Nordic rufostriatus specimens. A Finnish subarctic site had the same two genotypes as the type site. Considering both sites, the deviating genotype did not differ noticeably by morphology from the main group. For example, the deviating specimen had narrower and more amygdaloid spores than the main group specimen at the Finnish site, but this was other way round at the type site. Furthermore, the isotype of $C$. hemitrichoides was a genetic intermediate between the two genotypes, since it had an ambiguous base in the deviant position. Cortinarius hemitrichoides is reduced to a synonym of $C$. rufostriatus, considering also their similar morphology (Bidaud et al. 2010).

The morphology of $C$. rufostriatus varied much. The following description is based on Nordic collections. PILEUS 4-33 $\mathrm{mm}$ in diameter; conical when young, then campanulate, convex or applanate, usually with an obtuse or acute umbo; red brown, dark brown, or rarely orange brown, centre often blackish; delicately flocculose or fibrillose overall or only at margin, at times centre with a pale grey cover or margin with whitish veil remnants, translucently striate. LAMELLAE rather broad or broad, emarginate or narrowly adnate, subdistant to distant; yellow 

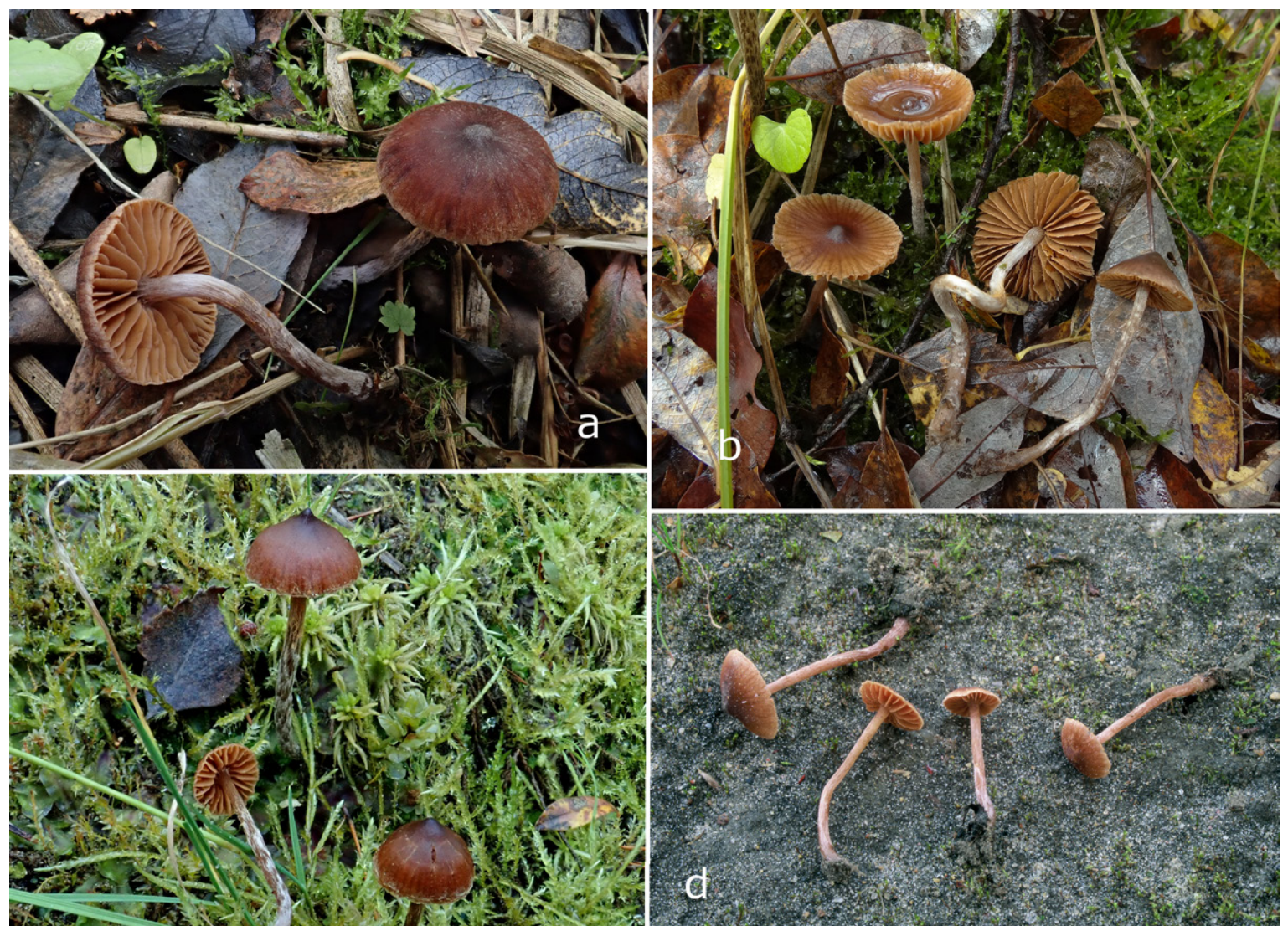

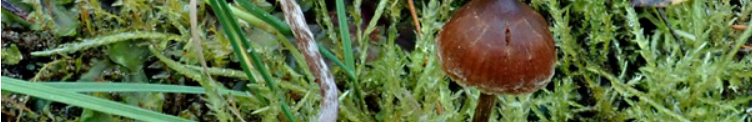

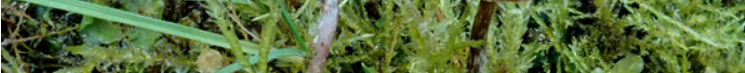

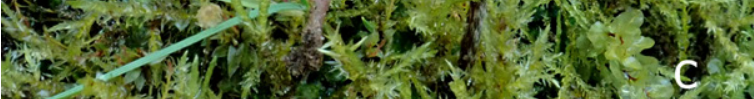

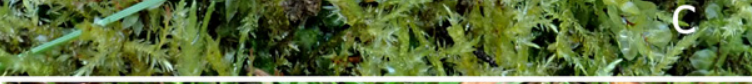

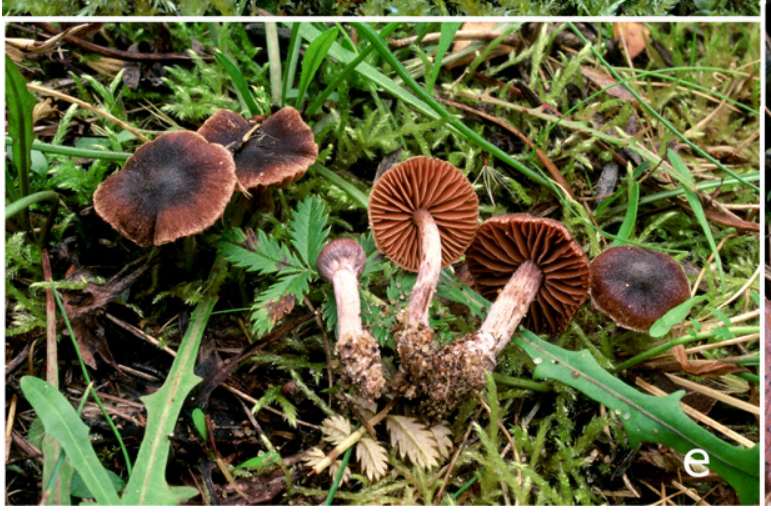

ब.
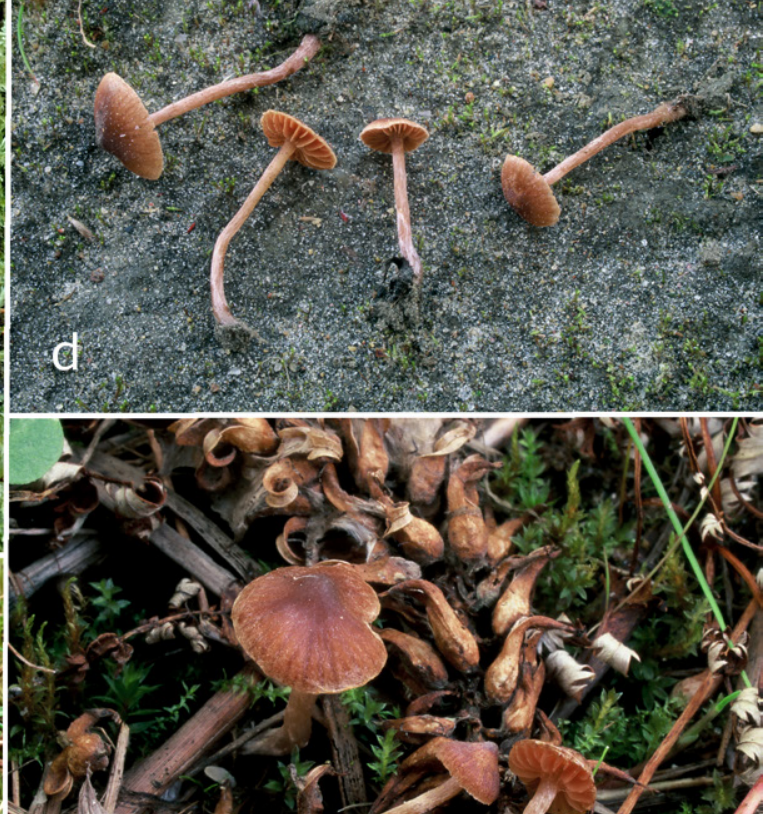

Fig. 1. Cortinarius rufostriatus, Finland. a Valtimo, KK 79/19. b Valtimo, KK 619/16. c Posio, KK 102/19.

d Utsjoki, KK 466/05. e Kalajoki, KK 258/04. f Kalajoki, KK 259/04. 
brown, red brown, orange brown or dark brown, edge paler or concolorous. STIPE usually slender, $11-78 \mathrm{~mm}$ long, $1-4 \mathrm{~mm}$ wide; equal, base at times clavate; red brown, dark brown or rarely pale yellow brown, rarely with a violaceous hue; often thickly pale grey or whitish fibrillose, at times flocculose or with a white band. CONTEXT more or less concolorous with the surface. CORTINA pale grey or whitish. SMELL not distinctive or faintly raphanoid. SPORES $9.0-\underline{10.6}-12.1 \times 5.2-\underline{6.3}-7.4 \mu \mathrm{m}$, range of mean values $10.3-10.9 \times 6.0-6.8 \mu \mathrm{m}, \mathrm{Q}=1.47-\underline{1.69}-2.05$, range of mean $Q$ values 1.62-1.79 (100 spores from 10 collections); usually narrow ellipsoid, often or occasionally with a tapering apex, rarely some spores distinctly amygdaloid or predominantly with a broad apex, some or many spores with a suprahilar depression; usually moderately to rather strongly verrucose, more rarely strongly or weakly verrucose; moderately to rather strongly dextrinoid. CHEILOCYSTIDIA-like structures present in some collections, hyphoid. LAMELLAR HYPHAE usually smooth or slightly encrusted.

The collections originate from the middle boreal zone to the alpine zone. The species seemed to be more common in Salix thickets along lakes and rivers in the northern boreal zone than further south. It also grew on a seashore near S. phylicifolia and Alnus incana. The soil varied from sand to muddy.

Cortinarius rufostriatus and the divergent $C$. casimiri group were not observed to have clear morphological differences. Considering the ITS and RPB2 sequences, C. casimiri may include more than one species. Cortinarius casimiri is regarded as very common (Niskanen et al. 2012b) and only a few $C$. casimiri specimens were examined thoroughly, which is why the following comparison is preliminary. Cortinarius rufostriatus fungi seemed on average smaller, more slender and more reddish than usual for C. casimiri. A rufostriatus collection from seashore had galerinoid orange brown fruitbodies. The spore sizes overlapped, but the usual spore size of $C$. rufostriatus was ca. 9.5-11.5 $\times 5.5-6.5$ $\mu \mathrm{m}$ and of C. casimiri ca. $10-12 \times 6.5-7.5 \mu \mathrm{m}$. The mean spore sizes of the $C$. casimiri specimens were $11.0-11.8 \times 6.5-7.1(\mathrm{n}=7)$, except one casimiri collection, genetically identical with the $C$. casimiri var. hoffmannii type sequence (Suárez-Santiago et al. 2009), had smaller spores with mean $10.7 \times 6.3 \mu \mathrm{m}$.
Suárez-Santiago et al. (2009) also found the spores of var. hoffmannii exceptionally small. One rufostriatus specimen had exceptionally wide spores with mean width $6.8 \mu \mathrm{m}$. The verrucosity and dextrinoidity of spores as well as hyphal incrustations were similar for C. rufostriatus and C. casimiri. An examined C. subsertipes Romagn. specimen of Romagnesi had very wide spores and an ITS sequence identical with some $C$. casimiri sequences, supporting their conspecifity (e.g. Suárez-Santiago et al. 2009).

HOLOTYPE: Cortinarius rufostriatus J.Favre. Switzerland, Graubünden, S-charl, Val Sesvenna, Marangun, alt. $2400 \mathrm{~m}$, among Salix herbacea, 24.VIII.1943 J. Favre 164a (GK13511). - Part 164a (Horak 1987) with 3 fruitbodies: spores 9.0- 10.7$11.5 \times 5.9-\underline{6.5}-7.0 \mu \mathrm{m}, \mathrm{Q}=1.45-\underline{1.64}-1.83(\mathrm{n}=20)$; ordinary or narrow ellipsoid, rarely cylindrical, occasionally a tapering apex; rather weakly to moderately verrucose; rather weakly to rather strongly dextrinoid. Part 164a-X with 2 fruitbodies: spores $10.1-\underline{11.2}-13.1 \times 5.5-\underline{6.2}-6.9 \mu \mathrm{m}, \mathrm{Q}=1.59-\underline{1.82}-$ $2.03(\mathrm{n}=20)$; narrow ellipsoid, cylindrical or amygdaloid, rarely a suprahilar depression; weakly to rather weakly verrucose; rather weakly to rather strongly dextrinoid.

ISOTYPE: Cortinarius hemitrichoides Bidaud \& Moënne-Locc. France, Savoie, Les Arcs, lac Marloup, alt. 2500 m, by Salix herbacea, 25.VIII.1990 leg. A. Bidaud, AB 90-08-118 (Herb. A. Bidaud). - Part of type as a loan. Spores 9.0- $10.7-12.2 \times 5.5-\underline{6.0}-6.8$ $\mu \mathrm{m}, \mathrm{Q}=1.53-1.77-2.03(\mathrm{n}=20)$; ellipsoid, cylindrical or subamygdaloid, rarely amygdaloid, shape very variable; rather weakly verrucose; weakly dextrinoid. Cystidia not observed. Lamellar hyphae slightly to moderately encrusted.

SPECIMEN EXAMINED: Cortinarius subsertipes Romagn. Locality unknown, deciduous forest, 1.IX.1951 leg. P. Ostoya, H. Romagnesi $51 \underline{239}$ (PC, Herb. Romagnesi). - Spores 9.7- $10.7-12.0 \times 6.0-$ $\underline{7.0}-7.8 \mu \mathrm{m}, \mathrm{Q}=1.28-\underline{1.53}-1.74 \quad(\mathrm{n}=20)$; broadly ellipsoid, rarely narrow ellipsoid or cylindrical, rarely slightly tapering at apex, suprahilar depression occasional; usually moderately verrucose, at times apex rather strongly verrucose, verrucae larger at apex; rather weakly dextrinoid. Some lamellar hyphae rather strongly encrusted.

OTHER SPECIMENS EXAMINED: C. casimiri: FINLAND. Varsinais-Suomi. Turku, Ruissalo, nature 
reserve, mixed herb-rich forest, 6.X.2006 Kokkonen 1246/06\%. Pohjois-Karjala. Kesälahti, Marjoniemi, moist Betula site, 21.IX.2004 S. Huhtinen 04/54*. Nurmes, Vihtasenlampi, shore forest, base of Salix pentandra, near Betula, 9.IX.2003 Kokkonen 495/03*. Inarin Lappi. Utsjoki, Tsuomasvarri, near Salix glauca, S. myrsinites, S. myrsinifolia ssp. borealis and Betula pubescens, 26.VIII.2005 Kokkonen 503/05*. ICELAND. Suđur-ĺsland. Rangárping eystra, Básar, Betula pubescens forest with scattered Salix, near Betula and S. phylicifolia, 14.IX.2017 Kokkonen 331/17*, Snorrariki, Betula pubescens forest with scattered Salix lanata and S. phylicifolia, 13.IX.2017 Kokkonen 336/17*, 16.IX.2017 Kokkonen 329/17, 330/17*. C. rufostriatus: FINLAND. Keski-Pohjanmaa. Kalajoki, Hiekkasärkät, 10.IX.2004 Kokkonen 238/04, 258/04*, 259/04*, 260/04, 261/04. Pohjois-Karjala. Valtimo, Haapakylä, Heinälampi, 24.IX.2002 Kokkonen 41/02\%, 20.IX.2003 Kokkonen 718/03*, 752/03, 26.IX.2009 Kokkonen 354/09, 14.IX.2019 Kokkonen 79/19*, Liuhanniemi, 30.IX.2016 Kokkonen 619/16*. Koillismaa. Kuusamo, Vuotunki, 2.9.2005 Kokkonen 394/05. Posio, Korouoma nature reseve, 14.VIII.2006 Kokkonen 161/06, 19.IX.2019 Kokkonen 102/19*. Salla, Kotala, 20.VIII.2008 Kokkonen 87/08* \& J. Vauras. Sompion Lappi. Savukoski, Tulppio, 22.VIII.2008 Kokkonen 116/08*. Enontekiön Lappi. Enontekiö, Kaaresuvanto, 20.VIII.2006 Kokkonen 263/06, 273/06*, Palojoensuu, 19.VIII.2006 Kokkonen 252/06*, Peltovuoma, 22.VIII.2006 Kokkonen 301/06\%. Inarin Lappi. Utsjoki, Pulmankijärvi, 28.VIII.2005 Kokkonen 465/05*, 466/05*467/05. ICELAND. Suđur-Îsland. Rangárping eystra, Valahnúkur, among S. herbacea, near S. arctica and Betula, 16.IX.2017 Kokkonen 334/17*, 344/17. NORWAY. Nord-Trøndelag. Levanger, Hårskallen, near S. herbacea, 22.VIII.2016 Kokkonen 311/16*. SWEDEN. Lule Lappmark. Gällivare, Nieras, near S. herbacea, 30.VIII.2016 Kokkonen 1403/16*. SWITZERLAND. Graubünden. Scuol, Val Sesvenna, among S. herbacea, alt. 2525 m, 17.VIII.2017 Kokkonen 275/17*, $276 / 17^{*}$.

\section{CORTINARIUS COMATUS COMPLEX}

Cortinarius comatus J.Favre, Ergebn.

Figure 2

Wiss. Unters. Schweiz. Natl. Parks 5 (33): 202 (1955)

A squamulose species occurring rarely in boreal $\mathrm{Sa}$ lix thickets was identified as $C$. comatus by comparing morphology and ITS sequences with the type and three alpine collections from France, Italy and Switzerland. Cortinarius comatus was described from the Swiss Alps (Favre 1955). The species is characterized by dark red brown fruitbodies, acute umbo, and both pileus and stipe with pale brown, cream or whitish squamules or flocculae. The veil may also be white (C. rusticellus in Bidaud et al. 2012). As an addition to the description in Funga Nordica (Niskanen et al. 2012b), the pileus diameter of boreal fungi reached $31 \mathrm{~mm}$ and stipe size $60 \times 4 \mathrm{~mm}$. Sometimes the stipe and/or pileus were only delicately fibrillose, and rarely the pileus appeared as smooth. The spores were usually moderately verrucose, rather large with mean 9.1-9.5 × 5.7-5.9 $\mu \mathrm{m}(\mathrm{n}=4)$, ellipsoid or subamygdaloid, and usually weakly dextrinoid. The lamellar hyphae were strongly encrusted and had dark flecks. The alpine collections from Italy and Switzerland had shorter spores than the type and the boreal specimens (mean 8.5-8.6 × 5.7-6.1 $\mu \mathrm{m}$ ), whereas the collection from France had larger spores (mean $10.6 \times 6.7 \mu \mathrm{m}$ ).

The slightly deficient ITS 1 sequence of the type was identical with the boreal, French and Swiss collections and deviated by one indel from the Italian collection. The ITS and RPB2 sequences differed slightly among all specimens, but the variation was regarded as intraspecific. The Swiss and Italian collections had one different base in the ITS region compared with the French and most Finnish collections. In addition, the RPB2 sequences deviated only by one base at most from each other, with one collection having an ambiguous base in the deviating position. Among the Finnish specimens, the ITS sequences deviated by 2 bases and an indel at most from each other, but several specimens had ambiguous bases in the deviating positions. The site with the most deviating specimen included two other sequenced specimens, which had ambiguous bases in one of the deviating positions. Furthermore, the 

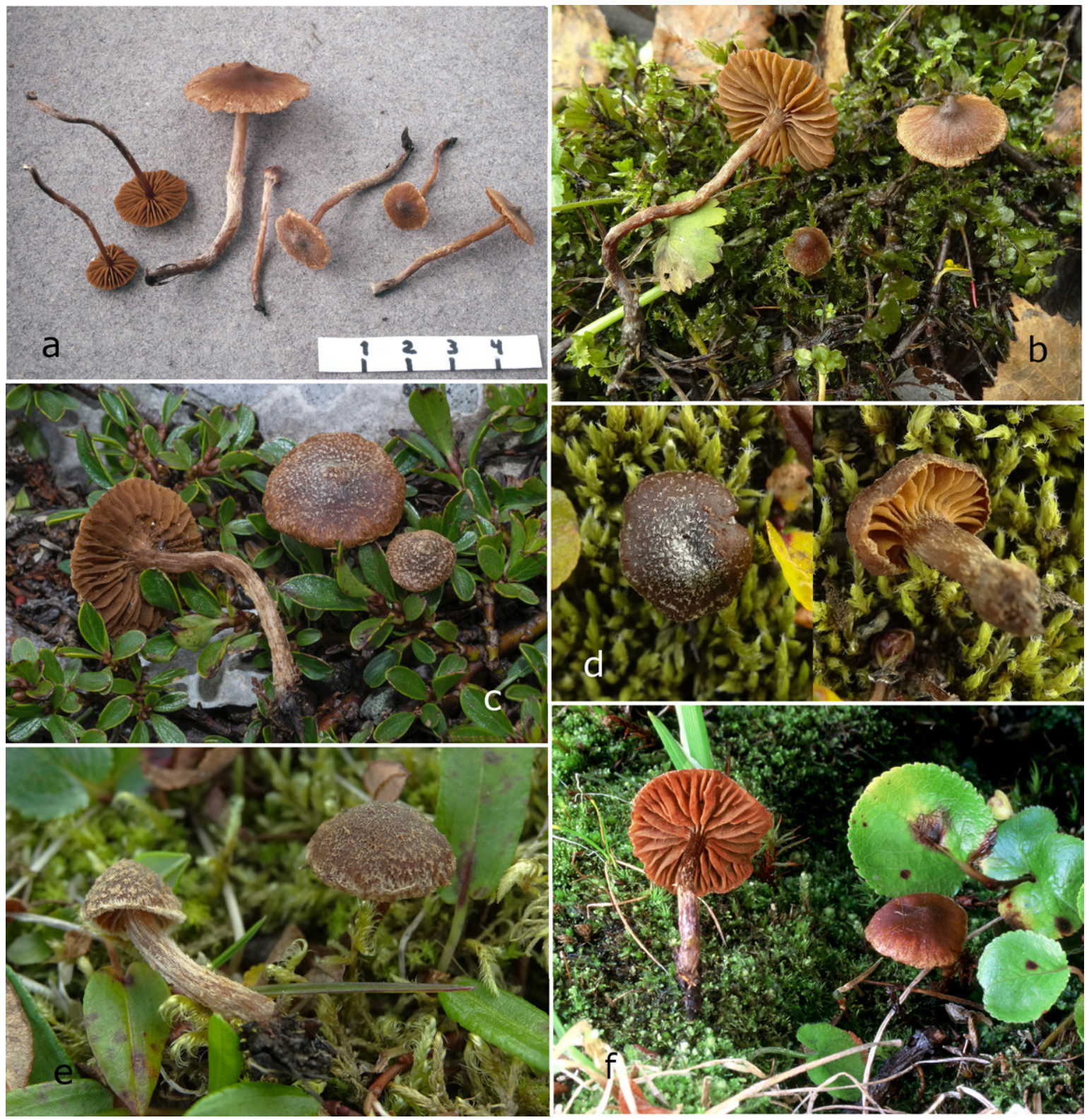

Fig. 2. Cortinarius comatus complex. a C. comatus. Finland, Nurmes, KK 624/03. b C. comatus. Finland, Nurmes, KK 425/16. c C. comatus. Italy, 14 Aug 2017 E. Campo. Photo E. Campo. d C. sagarum. Iceland, holotype. e C. sagarum. Norway, KK 307/16. f C. vulpicolor. Finland, Utsjoki, KK 464/05. 


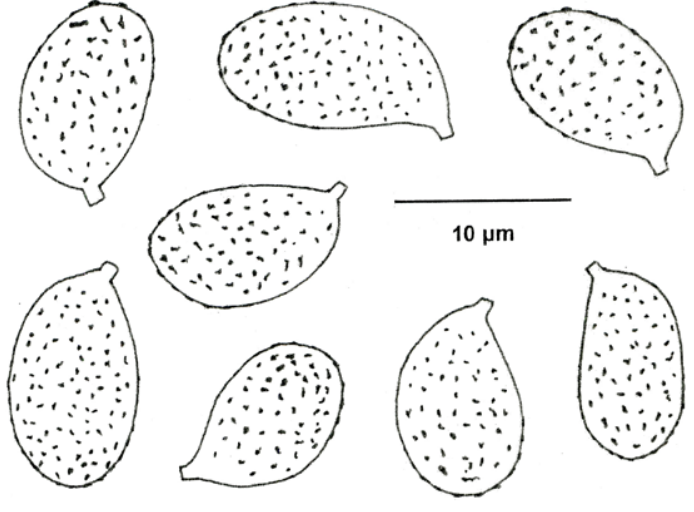

Fig. 3. Cortinarius sagarum. Holotype: spores.

RPB2 sequence of the most deviating specimen was identical with the other Finnish RPB2 sequences including a sequence from the same site.

In addition to shore thickets, $C$. comatus grew with boreal Salix bushes in a shore forest with mixed stand and among Sphagnum and Mnium mosses in a swamp with S. phylicifolia and S. lapponum. Cortinarius comatus is probably connected only with Salix.

LECTOTYPE: Cortinarius comatus J.Favre. Switzerland, Graubünden, Val Plavna, National Park, among Salix reticulata and S. retusa, alt. $2100 \mathrm{~m}$, 15.VIII.1941 J. Favre ZA 146a (GK 13276a). - Spores 8.4- $\underline{9.6}-10.6 \times 5.6-\underline{6.2}-7.1 \mu \mathrm{m}, \mathrm{Q}=1.41-\underline{1.55}-$ $1.67(\mathrm{n}=20)$; rather broadly ellipsoid, rarely subamygdaloid; weakly verrucose; weakly dextrinoid.

OTHER SPECIMENS EXAMINED: FINLAND. Pohjois-Karjala. Nurmes, Pahakala, 13.VII.2003 Kokkonen 45/03*, 8.IX.2003 Kokkonen 525/03*, 15.IX.2003 Kokkonen 624/03*, 8.IX.2016 Kokkonen $425 / 16^{*}$. Perä-Pohjanmaa. Kemijärvi, Vuostimo, 31.VIII.2005 Kokkonen 502/05*. Koillismaa. Kuusamo, Oivanki, 13.VIII.2006 Kokkonen 138/06*. Sompion Lappi. Savukoski, Tulppio, 22.VIII.2008 Kokkonen 117/08*. Inarin Lappi. Utsjoki, Pulmankijärvi, 28.VIII.2005 Kokkonen 505/05*. FRANCE. Savoie. Val d'Isère, among $S$. retusa on calcareous soil, 26.VIII.2005 A. Bidaud and A. Faurite-Gendron, AB 05-08-18 (Herb. A. Bidaud, as C. rusticellus)*.
ITALY. Belluno. Marmolada - Rocca Pietore, among S. retusa on calcareous soil, 14.VIII.2017 E. Campo (TUR-A)*. SWITZERLAND. Graubünden. Scuol, Val Plavna, W of Sur il Foss, alt. ca. 2220 m, near S. reticulata, 12.IX.2018 Kokkonen 834/18*.

Cortinarius sagarum Kokkonen, sp. nov. MycoBank MB833745

Figures $2 \mathrm{~d}$, e and 3

ETYMOLOGY: the name refers to the sagas of Iceland and Norway. Sagas means also wise women in Latin.

HOLOTYPE: Iceland, Suđur-Ísland, Rangárping eystra, Útgönguhöfði, alpine zone, alt. $700 \mathrm{~m}$, near Salix herbacea, 15.IX.2017 K. Kokkonen 350/17 (TUR; isotype ICEL), ITS MN841047, RPB2 MN807961.

PILEUS diameter 4-9 $\mathrm{mm}$ as dry; young obtuse conical, then convex; dark brown, with abundant white or pale brown squamules or fibrils; margin at times undulate or with scarce whitish veil remnants. LAMELLAE ventricose, emarginate or adnate, distant; rather dark yellowish brown, edge paler at least when young. STIPE $7-14 \mathrm{~mm}$ long and 1-2 mm wide as dry; equal or widening slightly downwards; dark brown, whitish fluffy fibrillose, at times with scarce pale brown squamules in the lower part. SPORES $8.9-\underline{10.3}-12.3 \times 5.8-\underline{6.7}-7.7$ $\mu \mathrm{m}$, range of mean values $10.0-10.6 \times 6.4-6.8 \mu \mathrm{m}$, $\mathrm{Q}=1.31-1.55-1.78$, range of mean $\mathrm{Q}$ values $1.47-$ 1.63 (60 spores from 3 collections); ellipsoid, occasionally cylindrical; moderately verrucose; weakly dextrinoid. BASIDIA 29-44 × 9-13 $\mu \mathrm{m} \quad(\mathrm{n}=16)$, 4-spored. CHEILOCYSTIDIA absent. LAMELlaR HYPHAE rather strongly or strongly encrusted and with dark flecks. PILEIPELLIS hyphae 3-25 $\mu \mathrm{m}$ wide, brownish, very coarsely encrusted, with abundant dark flecks.

HABITAT AND DISTRIBUTION: collections from two alpine zone locations near $S$. herbacea in Iceland and Norway, and from an arctic location in Svalbard; occurs also in the Austrian Alps according to three unidentified GenBank sequences.

SPECIMENS EXAMINED: ICELAND. SuđurÍsland. Rangárping eystra, Útgönguhöfði, 15.IX.2017 Kokkonen 350/17* (holotype). NORWAY. Nord-Trøndelag. Levanger, Hårskallen, 22.VIII.2016 Kokkonen 
$307 / 16^{*}$. Svalbard. Longyearbyen, village, by the church, 31.VII.1983 S. Huhtinen 83/139 (as C. gausapatus)*.

COMMENTS: Three Nordic arctic-alpine collections with squamulose fruitbodies differed from most $C$. comatus specimens by $2-3$ bases in ITS, and by 4-6 bases in RPB2 sequences. They were also genetically close to $C$. vulpicolor, differing from the type by 4 bases and 2 indels in ITS, but only by one base and a few indels in RPB2. Due to the morphological and genetic differences, they are described here as a new species, $C$. sagarum. The short type sequence of $C$. comatus was identical with both $C$. comatus and C. sagarum, but contrary to C. comatus, fungi of $C$. sagarum had convex pilei without umbo, stouter stipes, and larger spores excluding one C. comatus specimen. Cortinarius vulpicolor differed by smoother fruitbodies. It grew near C. sagarum at the Norwegian site. Cortinarius sagarum resembles morphologically C. gausapatus J.Favre and C. hemitrichoides Bidaud \& Moënne-Locc., which were genetically distant according to the type studies. Both of my sagarum collections were scarce and the description outlines the features of this small distinctive species. Three GenBank sequences of uncultured environmental samples from the Austrian Alps had identical sequences (Mühlmann et al. 2008, Oberkofler \& Peintner 2008, Oberkofler et al. unpubl.).

\section{Cortinarius vulpicolor M.M.Moser \& McKnight, Arctic Alpine Mycol. 2: 313 (1987)}

Cortinarius vulpicolor was described from Montana, USA, growing among Salix sp. in the alpine zone (Moser \& McKnight 1987). It was found from one northern boreal riverside, and from two alpine sites near S. herbacea in Finland and Norway. The ITS sequences were identical with the vulpicolor type, excluding 4 successive ambiguous bases in the Finnish alpine collection and one ambiguous base in the boreal collection. Cortinarius vulpicolor differed from $C$. comatus by 4-6 bases and 2-3 indels in ITS, and by 3-4 bases in RPB2. According to the RPB2 phylogenetic tree, C. vulpicolor is intermediate between C. comatus and C. sagarum, but not according to the ITS tree.

The morphology of the Nordic collections largely agreed with the description of $C$. vulpicolor (Moser
\& McKnight 1987). The fruitbodies were red brown (alpine) or yellow brown (boreal), the pileus was delicately fibrillose entirely or only at margin, the lamellae were distant, and the stipe had whitish veil fibrils. The pileus margin had sometimes whitish veil remnants. The spores were rather broadly ellipsoid with mean 9.4-10.0 × 6.1-6.3 $\mu \mathrm{m}(\mathrm{n}=3)$, densely weakly or rather strongly verrucose, and rather strongly dextrinoid. The lamellar hyphae were strongly encrusted and had sometimes dark flecks.

HOLOTYPE: Cortinarius vulpicolor M.M.Moser \& McKnight. USA, Montana, Beartooth Mts., plain north of Beartooth Pass, among Salix (herbacea-like), alt. $3550 \mathrm{~m}, 24$. VIII.1983 M. Moser (IB 1983/355). - Part of type as a loan. Spores 7.9- $\underline{8.6}-$ $9.9 \times 5.6-\underline{6.0}-6.7 \mu \mathrm{m}, \mathrm{Q}=1.31-\underline{1.45}-1-68(\mathrm{n}=20)$; rather broadly ellipsoid; weakly verrucose, verrucae somewhat larger at apex; moderately dextrinoid.

OTHER SPECIMENS EXAMINED: FINLAND. Enontekiön Lappi. Enontekiö, Palojoensuu, 19.VIII.2006 Kokkonen 258/06*. Inarin Lappi. Utsjoki, Tsuomasvarri, 27.VIII.2005 Kokkonen 464/05* NORWAY. Nord-Trøndelag. Levanger, Hårskallen, 22.VIII.2016 Kokkonen 309/16*.

\section{CORTINARIUS CUCUMISPORUS COMPLEX}

Figure 4

Cortinarius cucumisporus complex is closely related to the $C$. comatus complex, and to the common $C$. flexipes (Pers.:Fr.) Fr., which also seems to be a complex. All of them include squamulose species.

\section{Cortinarius cucumisporus M.M.Moser, Nova Hedwigia 14(2-4): 515 (1968)}

Cortinarius cucumisporus was described from the alpine zone in Austria (Moser 1968). According to Funga Nordica (Niskanen et al. 2012b), it has not been recorded from Fennoscandia before. In this study, C. cucumisporus was identified from an alpine site in Sweden, but it was not found from the boreal zone. The ITS sequence of the Swedish collection deviated only one indel from the type and a Swiss alpine collection, excluding 2 ambiguous bases. 


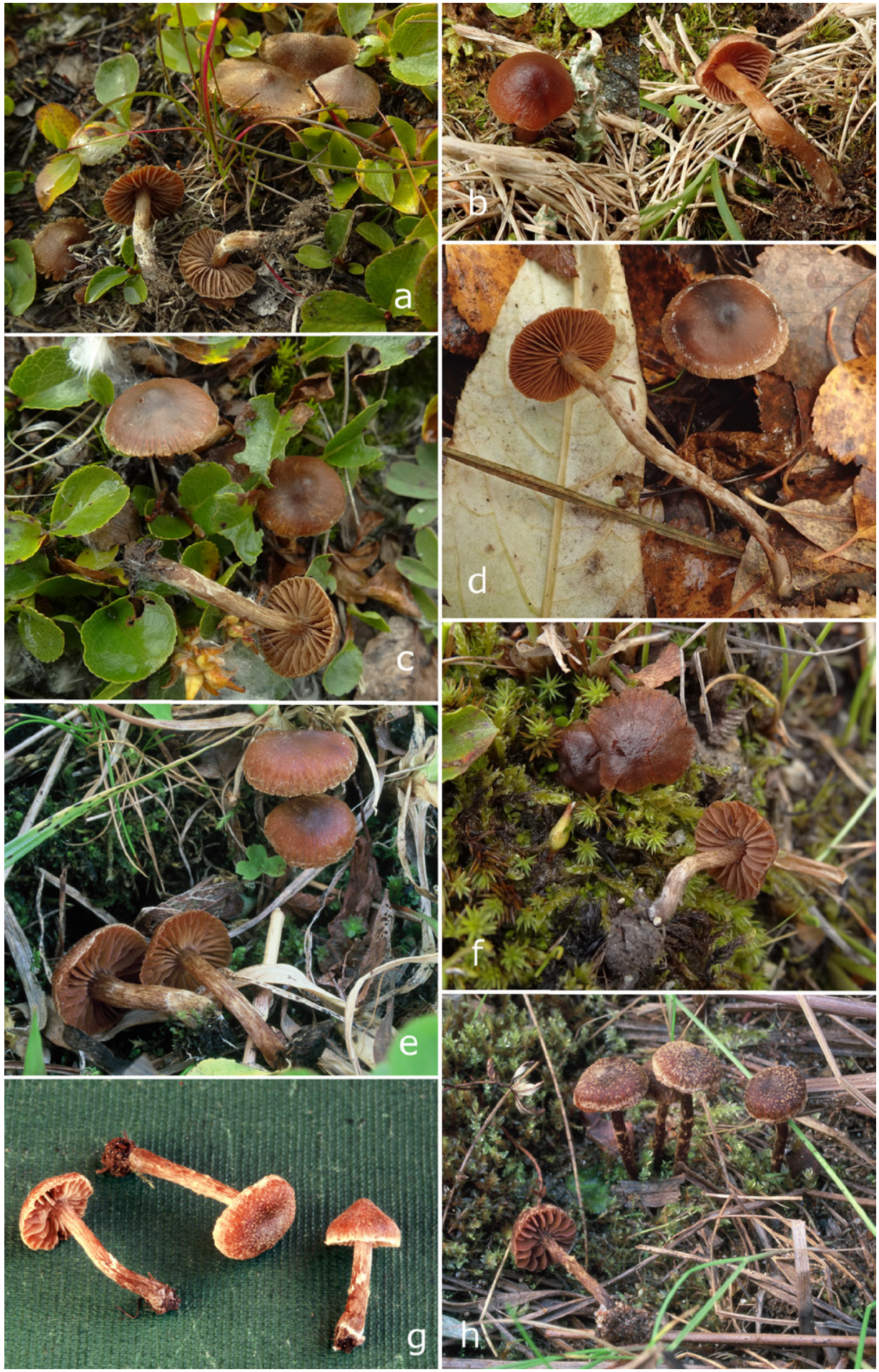

Fig. 4. Cortinarius cucumisporus complex. a C. cucumisporus. Sweden, KK 1378/16. b C. cucumisporus. Switzerland, KK 56/19. c C. stenospermus. Sweden, KK 1377/16. d C. stenospermus. Finland, Kuusamo, KK 710/18, Metsähallitus. e C. diasemospermus coll. Finland, Utsjoki, KK 511/05. f C. diasemospermus coll. Switzerland, KK 263/17. g C. diasemospermus coll. Finland, Kuusamo, KK 538/07. h C. diasemospermus coll. Finland, Kalajoki, KK 252/04. 
Cortinarius cucumisporus was genetically close to the diverse $C$. diasemospermus coll. group consisting of the types of $C$. diasemospermus Lamoure and C. stenospermus Lamoure as well as many boreal and alpine collections. Its ITS sequence deviated only by 1-2 bases, an inversion and 4 indels from the types. However, C. cucumisporus seems to be a separate species, despite similar morphology. All species are characterized for example by amygdaloid spores, but the spores of $C$. diasemospermus coll. were, on average, smaller and frequently ellipsoid in many collections.

The Nordic C. cucumisporus specimen had rimulose fibrillose and not translucently striate pilei in contrast to a nearby specimen genetically identical with $C$. stenospermus (Fig. 4). The centre was often cracked into squamules. The veil colour was mainly white or whitish, but also brownish hue occurred. However, the fibrillosity seems to vary much both within C. cucumisporus and some groups of $C . d i$ asemospermus coll. A Swiss cucumisporus fruitbody had only a delicately fibrillose, slightly rugulose pileus (Fig. 4b). According to Moser (1968), at least older pilei are fibrillose or squamulose, and the veil is mainly brownish. When compared micromorphologically with the nearby $C$. stenospermus, the Nordic C. cucumisporus spores were more fusoid and longer. The average spore size was $10.4 \times 4.9 \mu \mathrm{m}$ and the mean $Q$ value 2.14. The spores were rather weakly to moderately verrucose and moderately dextrinoid. The Swiss collection had the same mean spore size. Its spores were rather weakly verrucose and weakly dextrinoid.

HOLOTYPE: $C$. cucumisporus M.M.Moser. Austria, Tirol, Ötztal, inner Obergurgler Heide, above Untergurgl, among Salix reticulata and Arctostaphylos, 4.IX.1965 M. Moser (IB Nr.1965/0048). — Part of pileus as a loan. Spores $9.1-\underline{10.0}-11.6 \times 4.9-\underline{5.4}-$ $6.0 \mu \mathrm{m}, \mathrm{Q}=1.54-1.84-2.04(\mathrm{n}=20)$; amygdaloid or fusoid, rarely ellipsoid or cylindrical, rarely weakly constricted, very rarely with a suprahilar depression; weakly verrucose; indextrinoid.

OTHER SPECIMENS EXAMINED: SWEDEN. Lule Lappmark. Gällivare, Nieras, among Salix herbacea, 30.VIII.2016 Kokkonen 1378/16*. SWITZERLAND. Graubünden. Scuol, Val S-charl, Murters da Tamangur, alt. $2375 \mathrm{~m}$, among S. herbacea, 26.VIII.2019 Kokkonen 56/19*.
Cortinarius diasemospermus Lamoure, Trav. Sci. Parc Natl. Vanoise 9: 99 (1978), coll.

The ITS sequences of $C$. diasemospermus collections varied slightly, which raised a question, how many species are involved, and the species is treated collectively. Most specimens deviated 1 or 2 bases from each other, but the most divergent clade deviated by 3-5 bases and 2-3 indels from the types of $C$. diasemospermus and C. stenospermus. The before-mentioned types deviated by 1 base and 2 indels from each other. Cortinarius stenospermus may be a synonym of $C$. diasemospermus, but it could not be confirmed with this data set. The study of more DNA regions and collections with good morphological notes would help to delimit the species around $C$. diasemospermus.

The collections did not group genetically according to the habitats or locations, but all the larger groups occurred both in the boreal and alpine habitats, and identical ITS sequences could originate from distant locations. Also, nearby collections often varied genetically. All collections had rather similar morphologies. Dark red brown pilei, amygdaloid spores and strongly encrusted lamellar hyphae were usual common features. The fruitbodies were more distinctly fibrillose or squamulose in some groups, but a group with identical ITS sequences could include both smooth and squamulose fungi. Pelargonious smell was observed occasionally.

Both C. diasemospermus and C. stenospermus were described to grow with dwarf Salix in the French Alps (Lamoure 1978, 1987). Cortinarius stenospermus had longer spores with somewhat different shape compared with $C$. diasemospermus. Other differences were its longer stipe with a ring or a band and veil remnants in contrast to the short stipe with scarce veil of $C$. diasemospermus. The spore differences were not supported by this study. A piece of the partial type of $C$. stenospermus had about the same spore size as a piece of $C$. diasemospermus type, and the shapes were similar with frequent amygdaloid spores. The spores of the $C$. diasemospermus and C. stenospermus groups (Fig. 19) were also quite similar. A mixed collection of $C$. stenospermus type is possible, but more likely the spores varied within the specimen. The spore sizes and shapes of $C$. diasemospermus coll. could vary 
considerably within a group. The spores of both $C$. diasemospermus and C. stenospermus groups varied less in the Alps or among alpine zone specimens than among boreal specimens. For the $C$. diasemospermus group, the range of mean spore size of the hemiboreal and boreal specimens was 8.3-9.6 $\times 4.8-4.9 \mu \mathrm{m}$, with mean $\mathrm{Q}=1.69-1.96(\mathrm{n}=3)$, and for the alpine specimens $9.2-9.5 \times 5.4-5.5 \mu \mathrm{m}$ with $\mathrm{Q}=1.69-1.73$ ( $\mathrm{n}=3)$. For the C. stenospermus group, the range of mean spore size of the boreal specimens was 8.0-9.1 $\times 4.7-5.1 \mu \mathrm{m}$, with range of mean $\mathrm{Q}=1.69-1.78(\mathrm{n}=2)$, of the alpine specimens $8.7-8.9$ $\times 4.7-5.4 \mu \mathrm{m}$ with $\mathrm{Q}=1.64-1.88(\mathrm{n}=5)$, or of the Alps specimens $8.7-8.9 \times 5.1-5.4 \mu \mathrm{m}$ with $\mathrm{Q}=1.64-1.76$ $(n=3)$. Both groups included specimens with predominantly amygdaloid or ellipsoid spores. The spores were rather weakly to strongly verrucose and weakly to moderately dextrinoid.

Distinct macromorphological differences were neither found between the C. diasemospermus and C. stenospermus groups. Some C. diasemospermus fungi had a white band on stipe like $C$. stenospermus. However, C. stenospermus may have characteristically more abundant veil. Some $C$. stenospermus specimens had pilei with white veil patches near the margin and the pilei were squamulose in one specimen. The data for stipe size comparisons was insufficient, but especially boreal stenospermus exsiccata were larger than diasemospermus exsiccata. The boreal fungi had longer stipes than alpine fungi in both groups, likely due to the vegetation. No specimens were observed with distinctly violaceous-tinged lamellae. Lamoure $(1978,1987)$ reported young fruitbodies of both species to have violaceous-tinged lamellae.

Two specimens were genetically intermediate between the $C$. diasemospermus and $C$. stenospermus groups (KK511/05, KK355/17). They had an ambiguous base in the deviant position. The specimens originated from the alpine zone of Finland and from subarctic Iceland. Generally, the groups within $C . d i$ asemospermus coll. were separated rather well with few intermediates in ITS sequences. A group with seven specimens (Group 2 in Fig. 19) deviating from the $C$. diasemospermus group by one base and 2-3 indels included only one partial intermediate specimen. Some specimens of this group had distinctly violaceous-tinged lamellae and the stipe base could be violaceous. The pileus varied from glabrous to squamulose. The mean spore size and spore shape varied considerably similarly to the diasemospermus and stenospermus groups, mean range 8.2-9.8 $\times$ 4.9-5.5 $\mu$ m with mean $\mathrm{Q}=1.53-1.92(\mathrm{n}=6)$, but the spores were moderately to rather strongly dextrinoid in contrast to the other two groups. All specimens of Group 2 were from the northern boreal to the alpine zone of Finland.

According to Funga Nordica (Niskanen et al. 2012b), C. diasemospermus grows with many tree species and is common from the temperate to the alpine zone. In this study, C. diasemospermus coll. occured commonly with Salix bushes and dwarf Salix in the northern boreal and alpine zones, but rarely further south. The single $C$. diasemospermus specimen from the hemiboreal zone was from a mixed herb-rich forest with e.g. Quercus robur and apparently without Salix. Cortinarius stenospermus grows in the temperate zone according to a GenBank sequence from Poland (identified as $C$. diasemospermus, KX355534, Kalucka unpubl.). The only diasemospermus coll. specimens from the middle boreal zone grew on a seashore near Salix phylicifolia and Alnus in this study. They belonged to the most separate clade likely representing a separate species (Group 4 in Fig. 19). They had a distinctly brownish veil in contrast to the nearly always white or whitish veil of others. They may represent $C$. phaeopygmaeus J.Favre. Two collections of Group 4 originated from the Swiss Alps, where they were found among S. herbacea.

The two specimens of Group 1 (Fig. 19) were from the alpine zones of Finland and Switzerland. Group 1 deviated by one base and 1-2 indels from the $C$. diasemospermus group. Its spores were at the broader end with mean range 9.0-9.3 $\times 5.5-5.8$ $\mu \mathrm{m}$ and mean $\mathrm{Q}=1.59-1.64$. Group 3 deviated from the $C$. stenospermus group by 2 bases and 1-2 indels. Both specimens of this group had squamulose pilei and stipes. Their spores resembled each other with mean range 8.7-9.0 $\times 5.5-5.6 \mu \mathrm{m}$. The spores were mostly ellipsoid, rather weakly verrucose and weakly dextrinoid. Both were collected from the northern boreal zone of Finland.

HOLOTYPE: Cortinarius diasemospermus Lamoure. France, Savoie, Vanoise, Région de Pralognan, Roc du Tambour, alt. NW 2400 m, Salix herbacea, 
19.VIII.1969 D. Lamoure (LY). - Type scarce with a piece of pileus, a stipe and small fragments. Spores 8.3- $\underline{9.5}-11.0 \times 5.0-\underline{5.5}-6.0 \mu \mathrm{m}, \mathrm{Q}=1.44-\underline{1.73}-$ $1.94(\mathrm{n}=20)$; amygdaloid or ellipsoid, rarely constricted; moderately verrucose; weakly dextrinoid. Lamellar hyphae strongly encrusted and with dark flecks.

HOLOTYPE: Cortinarius stenospermus Lamoure. France, Savoie, Vanoise, Région de Pralognan, under Cirque du Dard, alt. N 2200 m, Dryas and Salix reticulata, 28.VIII.1963 D. Lamoure (LY). - Part of type as a loan. Spores 8.1- $\underline{8.9}-10.3 \times 4.9-\underline{5.4}-6.3$ $\mu \mathrm{m}, \mathrm{Q}=1.51-\underline{1.64}-1.87(\mathrm{n}=20)$; amygdaloid, rarely ellipsoid or constricted; moderately verrucose; indextrinoid or weakly dextrinoid. Lamellar hyphae strongly encrusted.

OTHER SPECIMENS EXAMINED: FINLAND. Varsinais-Suomi. Turku, Ruissalo, 11.X.2006 Kokkonen 1314/06* and J. Vauras. Keski-Pohjanmaa. Kalajoki, Hiekkasärkät, 9.IX.2004 Kokkonen 235/04*, 252/04*. Perä-Pohjanmaa. Posio, Korouoma nature reserve, 14.VIII.2006 Kokkonen 160/06*. Koillismaa. Kuusamo, SW of Siirtola, 24.IX.2018 Kokkonen 710/18*, Vuotunki, 31.VIII.2007 Kokkonen 538/07*, $548 / 07^{*}$ and J. Vauras. Kittilän Lappi. Kittilä, near the main village, 28.VIII.2008 Kokkonen 196/08*, Muonio, Pallastunturi, among S. herbacea, 18.VIII.2006 Kokkonen 235/06\%. Sompion Lappi. Savukoski, Ainijärvi, 21.VIII.2008 Kokkonen 106/08* and J. Vauras. Enontekiön Lappi. Enontekiö, near Kaaresuvanto, 20.VIII.2006 Kokkonen 274/06*, 275/06*, Palojoensuu, 19.VIII.2006 Kokkonen 246/06*, 261/06*, Peltovuoma, 22.VIII.2006 Kokkonen 298/06*, Saana, 21.VIII.2006, among S. herbacea, Kokkonen 290/06*. Inarin Lappi. Utsjoki, near Skallovaara, 29.VIII.2005 Kokkonen 476/05*, Tsieskuljoki, 24.VIII.2005 Kokkonen $225 / 05^{*}$, Tsuomasvarri, 27.VIII.2005, near S. reticulata and S. myrsinites, Kokkonen 511/05*. ICELAND. Suđur-l̂sland. Rangárping eystra, Útgönguhöfði, among S. herbacea, 15.IX.2017 Kokkonen $351 / 17^{*}$, Snorraríki, Betula pubescens forest with scattered Salix, near S. lanata, S. phylicifolia-hybrid? and Betula, 16.IX.2017 Kokkonen 355/17*, Valahnúkur, near S. herbacea, S. arctica and Betula, 16.IX.2017 Kokkonen 353/17*. ITALY. Trento. Soraga, Passo della Selle, alt. ca. $2300 \mathrm{~m}$, on calcareous soil among S. retusa with Euphrasia minima, 23.VIII.2006 E. Campo (as C. pauperculus, TUR-A)*. NORWAY. Nord-Trøndelag. Levanger, Hårskallen, near S. herbacea, 22.VIII.2016 Kokkonen 312/16*. SWEDEN. Lule Lappmark. Gällivare, Nieras, among S. herbacea, 30.VIII.2016 Kokkonen 1377/16*. SWITZERLAND. Graubünden. Scuol, Lai Sesvenna, alt. 2660 m, among $S$. herbacea, 17.VIII.2017 Kokkonen 286/17*, 313/17*, Piz Clünas, alt. 2640 m, near S. herbacea, 16.VIII.2017 Kokkonen 288/17*, Val Plavna, among Dryas and S. reticulata, 15.VIII.2017, Kokkonen $293 / 17^{*}$, Val S-charl, Valbella, alt. $2200 \mathrm{~m}$, among Dryas and S. reticulata, 26.VIII.2019 Kokkonen 51/19*, Val Sesvenna, alt. 2525 m, near S. herbacea, 14.VIII.2017 Kokkonen 263/17*. Val Müstair, Piz Cotschen, alt. 2595 m, near S. herbacea, 13.IX.2018 Kokkonen 835/18*.

\section{CORTINARIUS DECIPIENS COMPLEX}

Figure 5

Cortinarius decipiens (Pers.:Fr.) Fr. is involved in a difficult species complex. The specimens formed genetic continuums, which is why species were difficult to delimit. No identical ITS sequence with the decipiens neotype (Moënne-Loccoz \& Reumaux 1990b, Suárez-Santiago et al. 2009) was found from the boreal zone. The two closest clades deviated from the neotype only by 1-2 bases and 1-2 indels, and they are all treated here as $C$. decipiens. Since there appeared differences up to 3 bases within this group, and the RPB2 sequences were even more divergent, there are possibly more than one species. The decipiens group deviated by 3-4 bases and 0-2 indels from the somewhat morphologically different and genetically more uniform C. pulchripes group. Cortinarius pulchripes J.Favre is treated here as a separate species. It had characteristically larger spores and smaller fruitbodies than $C$. decipiens. This was remarkably clear within a site. Both species could occur at the same site without intermediates, and they were distinctly separate by the RPB2 sequences, which also support the separation. On the other hand, considering that the $C$. decipiens neotype is partially a genetic intermediate between the decipiens and pulchripes groups, C. pulchripes may be within the variation of $C$. decipiens.

Other species or groups belonging to the decipiens complex included $C$. fuscoflexipes, $C$. castaneus 


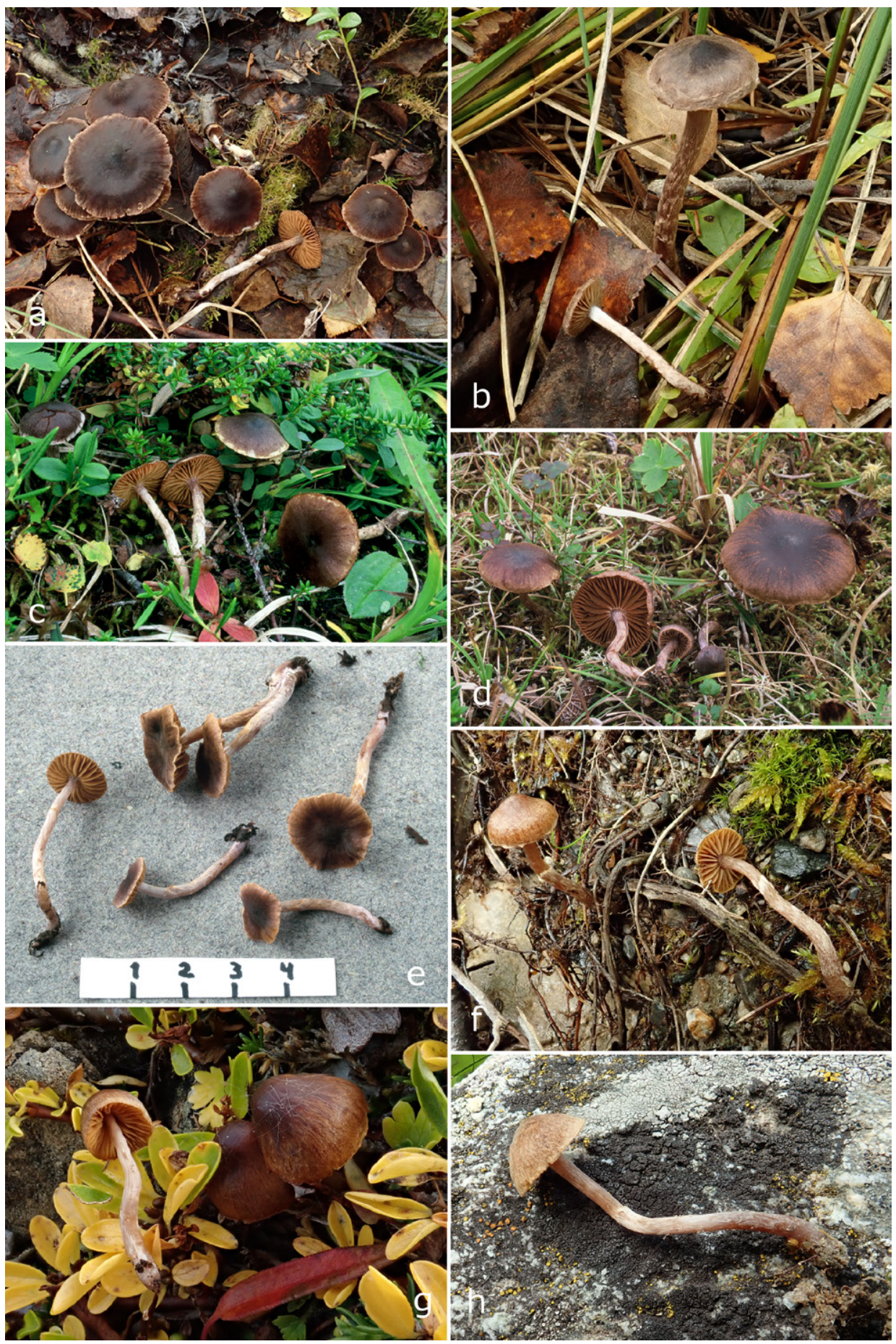

Fig. 5. Cortinarius decipiens complex. a C. decipiens. Finland, Kuusamo, KK 661/18, Metsähallitus. b C. decipiens. Finland, Kuhmo, KK 666/18, Metsähallitus. c Cortinarius sp. Finland, Utsjoki, KK 510/05. d C. fuscoflexipes. Finland, Utsjoki, KK 417/05. e C. pulchripes. Finland, Nurmes, KK 249/03. f C. pulchripes. Switzerland, KK 22/19. g C. castaneus? Switzerland, KK 826/18. h C. pulchripes. Switzerland, KK 58/19. 
neotype group, C. pseudofusisporus, and an unidentified group probably without Salix connection. Fungi belonging to this complex are widely distributed and not rare, which is why more recognized and likely also unrecognized species belonging to this complex have been described (e.g. in Atlas des Cortinaires series and Suárez-Santiago et al. 2009). To complete the taxonomy, a thorough research with abundant material would be needed. Suárez-Santiago et al. (2009) interpreted C. decipiens sensu lato as a highly variable species.

\section{Cortinarius decipiens (Pers.:Fr.) Fr., Epicr. Syst. Mycol.: 312 (1838)}

Cortinarius decipiens was neotypified from France growing with Alnus and Populus (Moënne-Loccoz \& Reumaux 1990b). The Finnish specimens resembled macroscopically the decipiens neotype by dark brown pileus and stipe with a pale grey or whitish cover or flocculae. The stipe apex had rarely a violet tinge, and the colour of lamellae varied among yellow brown, red brown and dark brown. The fruitbodies were generally rather large for a small Telamonia, the pileus reaching $51 \mathrm{~mm}$ and stipe $82 \times 8$ $\mathrm{mm}$. For the comparison to $C$. pulchripes, the largest pileus diameter varied $17-42 \mathrm{~mm}$ among decipiens exsiccata. The pileus had often pale veil patches near the margin.

The mean spore size varied $7.0-8.1 \times 4.2-5.3$ $\mu \mathrm{m}(\mathrm{n}=12)$, but most specimens had spores under 8 $\times 5 \mu \mathrm{m}$. The mean $\mathrm{Q}$ value was $1.51-1.82$. The spores were usually somewhat narrow ellipsoid, tapering at times towards apex, or rarely cylindrical, often with a suprahilar depression, moderately to strongly verrucose having often larger verrucae at apex, and usually weakly to moderately dextrinoid. Lamellar hyphae were usually without or only with slight incrustations.

Cortinarius decipiens grows both in lowland and alpine habitats. Salix is at least one host, since no other trees were present at two sites: S. phylicifolia, S. myrsinifolia and S. pentandra by a boreal lakeside, and $S$. herbacea at an alpine site. The boreal habitats were moist Salix thickets or shore forests by lakes, rivers, brooks or ditches, or moist mixed forests. In one case, Salix was not reported from the site, but only Alnus, Betula and Picea. In the alpine zone, it grew among S. reticulata and Dryas octopetala or among $S$. herbacea. The collections originated from the southern boreal to the alpine zone in Finland.

A specimen having an identical ITS sequence with the decipiens neotype was found from the Swiss Alps (KK823/18), which confirms the occurrence of C. decipiens both in lowland and alpine habitats. Its spores were rather large, mean $8.8 \times 5.7 \mu \mathrm{m}$, resembling thus more the spore size of $C$. pulchripes. Sometimes spores are larger in higher altitudes, but it was not evident among collections of this complex. Another Swiss alpine C. decipiens specimen deviated from the neotype by one base.

SPECIMENS EXAMINED: FINLAND. EteläHäme. Orivesi, Yröskulma, 17.IX.1999 J. Vauras 15582 (TUR-A)*. Pohjois-Häme. Laukaa, 12.IX.2002 Kokkonen 128/02\%. Pohjois-Karjala. Nurmes, Joki-Vastimo, 18.IX.2003 Kokkonen 710/03*, Metsä-Vastimo, 24.IX.2002 Kokkonen*, Pahakala 15.IX.2003 Kokkonen 620/03\%. Kainuu. Kuhmo, near Koirakangas, 8.IX.2018 Kokkonen 666/18*, Sotkamo, Tipasoja, 3.IX.2001 J. Vauras 17593, det. I. Kytövuori (TUR-A)*. Koillismaa. Kuusamo, near Petäjäkangas, 13.VIII.2006 Kokkonen 146/06*, SW of Siirtola, 24.IX.2018 Kokkonen 661/18*. Kittilän Lappi. Kittilä, near the main village, 27.VIII.2008 Kokkonen 176/08*. Inarin Lappi. Utsjoki, Tsieskuljoki, 24.VIII.2005 Kokkonen 212/05*, Tsuomasvarri, among $S$. reticulata, near S. herbacea, S. glauca and Betula nana, 26.VIII.2005 Kokkonen 459/05\%. SWEDEN. Lule Lappmark. Gällivare, Nieras, among $S$. herbacea, 30.VIII.2016 Kokkonen 1380/16*. SWITZERLAND. Graubünden. Val Müstair, Il Jalet, alt. 2380 m, near Dryas and S. reticulata, 14.IX.2018 Kokkonen 823/18*. Scuol, Val S-charl, N slope of Mot Radond, alt. 2275 m, near S. reticulata and Dryas, 27.VIII.2019 Kokkonen 60/19*.

Cortinarius pulchripes J.Favre, Beitr. Kryptogamenfl. Schweiz 10(3): 213 (1948) Synonym Cortinarius albonigrellus J.Favre, Ergebn. Wiss. Unters. Schweiz. Natl. Parks 5 (33): 202 (1955)

Favre (1948) described C. pulchripes growing under Salix, and also with Betula and Alnus, on peatland in 
subalpine Switzerland. The dark brown pileus was up to $30 \mathrm{~mm}$, the lamellae cinnamon yellow or pale cinnamon, and the slender stipe up to $60 \times 4 \mathrm{~mm}$. The stipe had a violet or purple red tinge, especially above the ring and at the base. The ITS sequence of the type was identical with my boreal and alpine collections with similar morphology. The ITS sequence of the C. albonigrellus type, collected from an alpine site among Salix herbacea (Favre 1955), deviated from the pulchripes type by one base and is regarded here as conspecific. Two collections from the alpine zone of Switzerland had identical sequences and agreed morphologically both with C. pulchripes and C. albonigrellus: the other had both ellipsoid and cylindrical spores. Also, one boreal specimen having an identical sequence with $C$. pulchripes resembled morphologically $C$. albonigrellus by a protruding ring and predominantly cylindrical spores (KK134/02). Some subalpine collections from Switzerland had fibrillose pilei (Fig. 5). They resembled morphologically the subalpine species $C$. dumetorum J.Favre (Favre 1960), which may be a synonym.

Cortinarius pulchripes is characterised by small fruitbodies having a dark brown or red brown pileus often with blackish centre and stipe with pale grey or whitish cover, which occasionally has a violet tinge entirely or at the base. The base may also be red. The pileus diameter varied $7-35 \mathrm{~mm}$, and stipe size $25-67 \times 1-5.5 \mathrm{~mm}$ among Finnish collections. Compared with $C$. decipiens, the largest pileus among exsiccata varied $11-21 \mathrm{~mm}$. The lamellae were yellow brown, red brown, or medium brown. The stipe had sometimes flocculae, a band, or a ring with a reddish rim (from spore deposit) similarly to the C. pulchripes painting by Favre (Favre 1948).

The mean spore size was $8.2-9.0 \times 4.8-5.2 \mu \mathrm{m}$ with mean $Q$ value 1.59-1.87 among five boreal collections, but one specimen had exceptionally short spores with mean $7.2 \times 5.0 \mu \mathrm{m}$ and $\mathrm{Q}$ value 1.46 , and the "albonigrellus" specimen had exceptionally long spores with mean $9.7 \times 5.0 \mu \mathrm{m}$ and $\mathrm{Q}$ value 1.94 . Otherwise, the spores resembled much $C$. decipiens spores. However, the spores were more often cylindrical or ovoid, sometimes even amygdaloid, and no more than weakly dextrinoid.

The habitats were boreal inland Salix thickets or shore forests, subalpine brooksides, and alpine sites near Salix herbacea, S. reticulata or S. myrsin- ites. Cortinarius pulchripes was collected from the transition between the southern and middle boreal zones to the alpine zone in Finland.

The ITS sequence of the type of $C$. atrocoeruleus M.M.Moser (Suárez-Santiango et al. 2009 and own result) deviated by 1-2 bases and an indel from the pulchripes sequences and is probably conspecific. Moser (1967) reported occasional pelargonioid smell, as was observed in one of my pulchripes collections. The type spores were more strongly dextrinoid than pulchripes spores. Brandrud et al. (1998) considered C. atrocoeruleus as a variety and Suárez-Santiango et al. (2009) as a synonym of $C$. decipiens. The types of $C$. sertipes Kühner and $C$. contrarius J.Geesink had identical sequences with $C$. atrocoeruleus (Suárez-Santiango et al. 2009).

HOLOTYPE: Cortinarius albonigrellus J.Favre. Switzerland, Pass of Taunter Pizza, west slope, near Pass Fuorn, alt. 2650 m, among Salix, sol de verrucano, 5.IX.1953 J. Favre (GK 13268). - Specimen with ca. 8 fruitbodies. Spores $8.0-\underline{8.9}-9.9 \times 4.4-\underline{4.8}-5.8$ $\mu \mathrm{m}, \mathrm{Q}=1.65-\underline{1.86}-2.11(\mathrm{n}=20)$; cylindrical, ellipsoid, or obtusely amygdaloid, rarely constricted; weakly or rather weakly verrucose; weakly dextrinoid.

HOLOTYPE: Cortinarius atrocoeruleus M.M. Moser. Austria, Tyrol, Gnadenwald, behind Gunkel, beside Moor, coniferous forest, 30.IX.1951 leg. and det. M. Moser (IB 1951/0161). - Part of type as a loan. Spores 7.5- $\underline{8.2}-9.4 \times 4.9-\underline{5.2}-5.8 \mu \mathrm{m}, \mathrm{Q}=$ 1.34- $1.54-1.80 \quad(\mathrm{n}=20)$; ellipsoid; moderately to rather strongly verrucose, verrucae larger at apex; moderately dextrinoid.

LECTOTYPE: Cortinarius pulchripes J.Favre. Switzerland, Hauts-Marais, Joux valley, near Pont, Sagnevagnard, "tourbière", 19.IX.1940 J. Favre (GK 7846). - Specimen with 5 fruitbodies in good condition. Spores 7.8- $\underline{8.5}-9.7 \times 5.2-\underline{5.6}-6.1 \mu \mathrm{m}$, $\mathrm{Q}=1.42-\underline{1.53}-1.69(\mathrm{n}=20)$; ellipsoid; usually rather weakly verrucose but apex often with few large verrucae, rarely a suprahilar depression or constricted; indextrinoid or slightly dextrinoid.

OTHER SPECIMENS EXAMINED: FINLAND. Pohjois-Karjala. Nurmes, Joki-Vastimo, 22.IX.2002 Kokkonen 134/02*, 18.IX.2003 Kokkonen 690/03*, Pahakala, 26.VIII.2002 Kokkonen 32/02*, 27.VIII.2003 Kokkonen 249/03*, 8.IX.2003 Kokkonen 520/03*, 15.IX.2003 Kokkonen 622/03*, 627/03*. Valtimo, Kalliojärvi, 9.IX.2008 Kokkonen 287/08*, 13.IX.2008 
Kokkonen 315/08*. Inarin Lappi. Utsjoki, Tsuomasvarri, among $S$. reticulata, 26.VIII.2005 Kokkonen 458/05*, near S. reticulata, S. herbacea and S. myrsinites, 26.VIII.2005 Kokkonen 461/05*. NORWAY. Troms. Storfjord, Helligskogen, near Salix bushes by pond, alt. ca. $300 \mathrm{~m}, 22$.VIII.2017 J. Vauras $32156 \mathrm{~F}$ (TUR-A)*. SWITZERLAND. Graubünden. Scuol, Piz Clünas, near S. herbacea, alt. 2640 m, 16.VIII.2017 Kokkonen 289/17*, Tarasp, W of Lai Nair, alt. 1540 $\mathrm{m}$, by a brook, beside $S$. foetida? and S. purpurea ssp. gracilis, 24.VIII.2019 Kokkonen 22/19*, Val Plavna, alt. $2320 \mathrm{~m}$, near S. herbacea, 15.VIII.2017 Kokkonen 295/17*, Val S-Charl, by Clemgia, alt. 1950 m, under S. foetida, 26.VIII.2019 Kokkonen 58/19*, 59/19.

\section{Cortinarius fuscoflexipes M.M.Moser \& McKnight, Arctic Alpine Mycol. 2: 306 (1987)}

Moser \& McKnight (1987) described C. fuscoflexipes from timberline near Salix, Yellowstone National Park, USA. The ITS sequence of holotype was identical or deviated up to one base and an indel from some Finnish collections excluding an ambiguous base. All specimens are regarded as conspecific. The type was an intermediate having an ambiguous base in a position where the Finnish specimens had different bases. The morphologies were similar. The habitats of the Finnish specimens were a mixed forest (Salix caprea, Alnus, Betula, Picea abies, Pinus sylvestris) in the southern boreal zone and the alpine zone on a fjeld near Salix reticulata. The fuscoflexipes type deviated by 5 bases and 2 indels both from the decipiens neotype and most $C$. pulchripes specimens. The RPB2 sequences of the three Finnish specimens deviated up to three bases from each other, but grouped together. However, C. fuscoflexipes could fall within the variation of $C$. decipiens according to the RPB2 sequences.

Cortinarius fuscoflexipes resembles C. decipiens and C. pulchripes. Its pileus was dark brown, and the stipe had a pale grey or whitish cover, but its lamellae appeared dark brown in contrast to the yellow brown or red brown lamellae of the other $d e$ cipiens complex specimens at the fjeld site (Fig. 5). The lamellae were described as dark brown also by Moser \& McKnight (1987). The stipe had sometimes a whitish ring or a band as with Moser \& McKnight.

The Finnish collections had smaller spores than the type, and about the same size as C. pulchripes: mean 8.6-9.0 × 5.3-5.7 $\mu \mathrm{m}$, mean $\mathrm{Q}=1.60-1.68$ $(n=3)$. The spores were ordinary or narrow ellipsoid, occasionally somewhat tapering towards apex, often with a suprahilar depression, and moderately to rather strongly verrucose and dextrinoid. The lamellar hyphae were smooth or variably encrusted.

HOLOTYPE: Cortinarius fuscoflexipes M.M. Moser \& McKnight. USA, Wyoming, Yellowstone National Park, Mt. Washburn, timberline, alt. 3300 $\mathrm{m}$, Picea engelmannii and Salix sp. (herbacea-like), 27.VIII.1983 leg. M. Moser, det. M. Moser and K. McKnight (IB 1983/0384). - Part of type as a loan. Spores 8.9- $\underline{9.7}-10.4 \times 5.4-\underline{6.0}-6.9 \mu \mathrm{m}, \mathrm{Q}=1.37-$ $\underline{1.61}-1.79(\mathrm{n}=20)$; ellipsoid, occasionally nearly amygdaloid; moderately to rather strongly verrucose; rather strongly to strongly dextrinoid.

OTHER SPECIMENS EXAMINED: FINLAND. Etelä-Savo. Savonlinna, Loikansaari, 17.IX.2004 J. Vauras 22884* and Kokkonen (TUR-A). Inarin Lappi. Utsjoki, Tsuomasvarri, 26.VIII.2005 Kokkonen $417 / 05^{*}, 509 / 05^{*}$.

\section{Cortinarius castaneus (Bull.:Fr.) Fr., Epicr. Syst. Mycol.: 307 (1838), ?}

Cortinarius castaneus neotype (Moënne-Loccoz \& Reumaux 1990a) deviated only by 2-3 bases and an indel from C. pulchripes specimens, and 5 bases and 2 indels from the $C$. decipiens neotype in ITS. The RPB2 sequence of a specimen having identical ITS sequence with the type was also separate. However, there exists a sequence continuum from the castaneus neotype via pulchripes to decipiens, which is why all may be conspecific.

It is doubtful, whether the neotype represents the original species of Fries. Fries $(1821,1838)$ described $C$. castaneus having lamellae with a violaceous tinge and occurring e.g. in Fagus and Quercus forests, whereas the castaneus neotype had rather vividly ochraceous red lamellae and occurred under Populus nigra (Moënne-Loccoz \& Reumaux 1990a). A genetically identical collection with the neotype from the Swiss Alps also had vividly ochraceous brown lamellae (Fig. 5g). It grew among Salix retu- 
sa. Due to the lamellar colour, at least $C$. pulchripes and $C$. decipiens do not agree with $C$. castaneus. Favre (1948) also emphasized that lamellae of C. pulchripes are never lilac in colour.

Cortinarius erythrinus has been interpreted variably. Moënne-Loccoz \& Reumaux (1990a) regarded it as a variety of $C$. castaneus. According to Fries (1838), C. erythrinus resembles C. castaneus strongly. However, the colour of lamellae was described as pale cinnamon, so the description implies more $C$. pulchripes or $C$. decipiens than C. castaneus. Some analysed herbarium specimens identified as C. erythrinus differed genetically distinctly from each other. Two of them from Germany matched C. inops coll., one German specimen along with a C. castaneus var. monspeliensis specimen from Italy matched $C$. vernus, and three had isolated sequences. Cortinarius erythrinus has not been typified, and its identity is left open in this publication.

NEOTYPE: Cortinarius castaneus (Bull.:Fr.) Fr. var. castaneus. France, Haute-Savoie, Sablière de Sillingy, under Populus nigra, among leaf litter, 7.V.1986 leg. P. Moënne-Loccoz, det. P. Reumaux (Herb. P. Moënne-Loccoz no. 275). - Spores 7.0- $\underline{7.7}-8.9 \times$ 4.6- $\underline{5.0}-5.3 \mu \mathrm{m}, \mathrm{Q}=1.37-\underline{1.55}-1.78 \quad(\mathrm{n}=20)$; ellipsoid, occasionally somewhat elongated or with a suprahilar depression; usually rather strongly verrucose or strongly verrucose at apex; weakly dextrinoid. Some lamellar hyphae weakly to moderately encrusted.

OTHER SPECIMEN EXAMINED: SWITZERLAND. Graubünden. Val Müstair, Costainas, alt. 2553 m, 11.IX.2018 Kokkonen 826/18*.

Isolated specimens identified as $C$. erythrinus: GERMANY. Bayern. Karlstadt, below Ruine Karlburg, under Corylus and Acer, 17.IX.1995 leg. \& det. L. Krieglsteiner / N. Arnold, WÜ4863, TK Nr. 6024/2 (REG 10942)*. ITALY. Parma. Borgotaro, Vighini, under Castanea sativa, 11.X.2006 E. Campo (TUR-A)*. Pordenone. Gaiardin-Caneva, Picea abies wood, calcareous soil, 2.VIII.2014 E. Campo (TUR-A)*.

\section{Cortinarius pseudofusisporus Bidaud, Atlas des Cortinaires 19: 1507 (2010)}

Cortinarius pseudofusisporus belongs genetically to the $C$. decipiens complex, where it is a morphologically distinctive species. It has very large, often fusoid spores and a cespitose growth habit (Bidaud et al. 2010). The ITS sequence of the holotype deviated 7 bases and 2 indels from the decipiens neotype sequence, $4-5$ bases and 1 indel from C. pulchripes sequences, and 4 bases and 1 indel from the castaneus neotype sequence. The type was collected from a fen under Betula pendula. The material of this study lacked corresponding specimens. Salix is likely not a host.

HOLOTYPE: Cortinarius pseudofusisporus Bidaud. France, Haute-Savoie, Éloise, Semine forest, alt. 500 m, fen, under Betula pendula, 7.X.1992 A. Bidaud 92-10-262 (Herb. A. Bidaud) - Part of type as a loan. Spores $9.0-\underline{10.9}-12.3 \times 5.3-\underline{5.8}-6.9 \mu \mathrm{m}$, $\mathrm{Q}=1.50-1.87-2.08(\mathrm{n}=20)$; obtusely fusoid or long ellipsoid, more rarely cylindrical, often a suprahilar depression; rather strongly to strongly verrucose and dextrinoid, verrucae larger at apex. Lamellar hyphae strongly encrusted and with dark flecks.

\section{Additional specimens}

A group of four boreal specimens collected near e.g. Populus tremula, Betula and Alnus, and only once near Salix, formed a separate clade. It deviated from the nearest species, C. fuscoflexipes, by 4 bases in ITS, representing likely a separate species. The RPB2 analysis supported the separation, but the group was also close to $C$. decipiens. The spore size was rather constant: mean $8.4-8.9 \times 5.3-5.5 \mu \mathrm{m}$, mean $\mathrm{Q}$ value $1.58-1.67(\mathrm{n}=4)$. Like with $C$. fuscoflexipes, the spores were moderately to rather strongly dextrinoid.

SPECIMENS EXAMINED: FINLAND. EteläHäme. Jämsä, Paatsalo, beside Populus tremula in Picea abies dominated forest, 18.IX.2004 Kokkonen 510/04* and J. Vauras. Pohjois-Häme. Rautalampi, Hanhitaipale, Picea abies dominated forest with Betula, Populus, Pinus and Sorbus, 14.IX.2004 T. Rahko*. Koillismaa. Kuusamo, Oulanka National Park, E of Jäkälävaara, a fairly moist forest with Picea, Betula, and Alnus, brookside with ferns, 24.VIII.2005 J. Vauras 23149 (TUR-A)*, SE of Pahtamasuo, rich ditch bank, near Salix phylicifolia, further away Picea and Betula, 25.IX.2018 Kokkonen 658/18*.

A partial genetically intermediate specimen was collected from the fjeld, where as many as three species were identified for this complex: C. decipiens, C. pulchripes and C. fuscoflexipes. The identifica- 

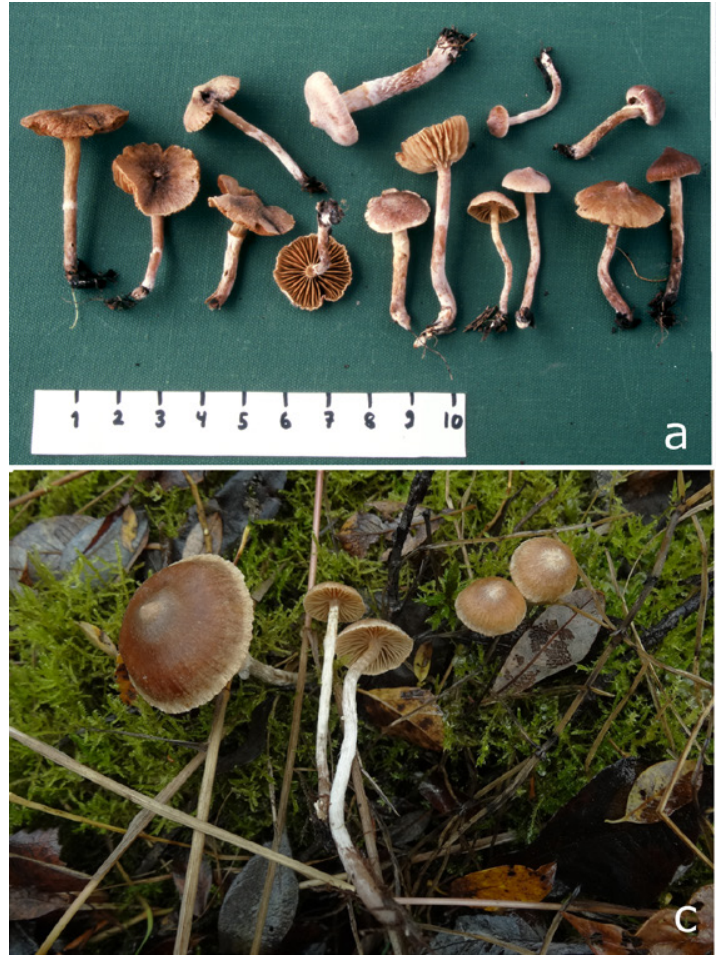

tion of this specimen remains open. It did not seem to be at least a F1-hybrid, since its ITS chromatograms lacked mixed peaks. Cortinarius pulchripes and the above-described unidentified group were genetically closest with 3 base ITS differences, but according to RPB2, it could belong to $C$. decipiens. Its spore size resembled C. pulchripes, but macroscopically it resembled $C$. decipiens by pale veil patches at the pileus margin (Fig. 5c).

SPECIMEN EXAMINED: FINLAND. Inarin Lappi. Utsjoki, Tsuomasvarri, near $S$. reticulata, further away S. glauca and Betula nana, 26.VIII. 2005 Kokkonen $510 / 05^{*}$.

\section{CORTINARIUS GOSSYPINUS}

H.Lindstr., Cortinarius Flora Photographica 5: 15 (2012)

Synonym Cortinarius mucronatus M.M.Moser \& McKnight, Arctic Alpine Mycol. 2: 312 (1987), nom. illegit.

Figure 6

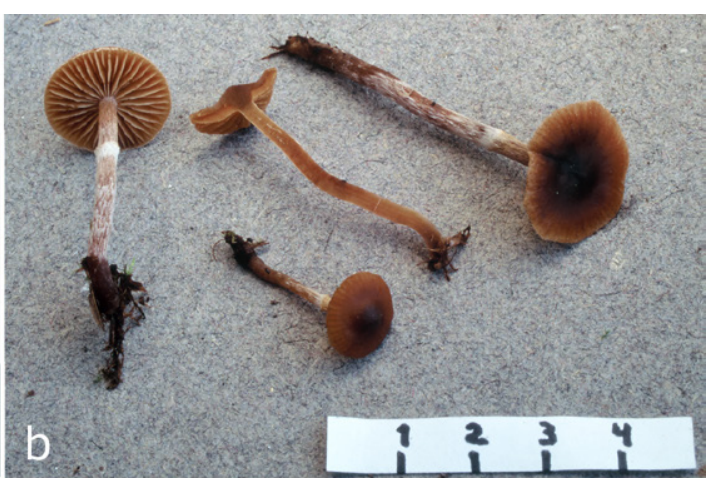

Fig. 6. Cortinarius gossypinus, Finland. a Nurmes, KK 131/02: three fruitbodies on the left, KK132/02: eight fruitbodies in the middle, KK 125/02: three fruitbodies on the right.

b Valtimo, KK 762/03.

c Valtimo, KK 618/16.

Cortinarius gossypinus occured commonly in boreal old Salix thickets in eastern and northern Finland. It was described recently from Sweden growing with Salix in moist deciduous forests and scrubs (Brandrud et al. 2012). Cortinarius mucronatus M.M.Moser \& McKnight is conspecific according to the type study. The ITS sequence of the mucronatus type deviated only by two indels from the $C$. gossypinus sequences of this study. Since C. mucronatus is illegitimate (Index Fungorum, Art. 53.1), C. gossypinus has priority. Cortinarius gossypinus type was not examined, but the species is well illustrated and described in the protologue, and no other species with a similar woolly pileus occur in boreal Salix thickets. Cortinarius mucronatus was described from the alpine zone in North America (Moser \& McKnight 1987). It had a smooth or fibrillose pileus in contrast to the pileus description of C. gossypinus, but otherwise their morphologies were similar. Cortinarius atomatus Bidaud ad int. (Bidaud et al. 2010) appeared also as conspecific. Its ITS sequence and morphology matched with C. gossypinus, except that the stipe apex was described as lilac. It was collected among S. herbacea from the French Alps. 
The morphology of $C$. gossypinus varied rather much. Its pileus was sometimes smooth as with $C$. mucronatus, and more constant features were the white band and floccosity of the stipe. It usually had a prominent acute umbo, but the umbo could also be absent. Compared with the descriptions of $C$. gossypinus (Brandrud et al. 2012, Niskanen et al. 2012b), the fruitbodies were larger in my material, the pileus diameter commonly reaching $30 \mathrm{~mm}$. The pileus size varied 7-40 $\mathrm{mm}$ and the stipe size $25-98 \times$ $1.5-5.5 \mathrm{~mm}$. The spore morphology varied considerably among collections and sometimes also within a collection. The mean spore size varied $8.2-9.7 \times$ $5.2-5.8 \mu \mathrm{m}$ and mean $\mathrm{Q}$ value $1.49-1.74(\mathrm{n}=13)$. The shape was usually ordinary or narrowly ellipsoid, some spores having a tapering apex, but the shape could be predominantly obtusely amygdaloid or subfusoid. Some collections had spores with frequent suprahilar depressions. The verrucosity varied commonly from weak to rather strong. The spores were usually moderately to rather strongly dextrinoid. The lamellar hyphae usually lacked incrustations or were only slightly encrusted, never strongly encrusted.

No distinct micro- or macromorphological differences were observed among collections or groups with slightly different ITS sequences. The ITS sequences deviated at most 3 bases from each other, but there always appeared intermediate sequences having ambiguous bases. Cortinarius atomatus had ambiguous bases in two of the deviating positions. Consequently, all specimens are regarded as conspecific. A Finnish alpine collection had an identical sequence with two arctic collections originating from Alaska and Svalbard (GenBank KC965870 Timling et al. 2014, UNITE UDB027282).

The collections of this study originated from the transition zone between the southern and middle boreal zones to the alpine zone, but the species occurs also in the hemiboreal zone (Niskanen et al. 2012b). In addition to inland shores, it was found from a swamp. It always grew with Salix, sometimes close to no other trees than S. phylicifolia and S. myrsinifolia, or dwarf Salix at the alpine sites. In Iceland, it was found near S. herbacea, S. arctica and Betula. The single fruitbody resembled at least by spores $C$. substriaepileus Melot, which was described from Iceland, but had a different habitat (Melot 1995). Bidaud et al. (2010) regarded C. gossypinus as a possible synonym of $C$. acutissimus
(Velen.) G.Garnier. Their description of a C. acutissimus form from France resembles morphologically $C$. gossypinus, but deviates by a weak raphanoid smell. The description of C. acutissimus by Velenovsky (1921) does not quite agree with $C$. gossypinus. The lamellae have a grey brown tinge, and the habitat is deciduous forests without mention of Salix.

HOLOTYPE: Cortinarius mucronatus M.M.Moser \& McKnight. USA, Wyoming, Beartooth Mts, Beartooth Pass, among Salix sp., 22.VIII.1983 M. Moser (IB 1983/0342). - Part of type as a loan. Spores 7.9- $\underline{9.0}-10.0 \times 5.2-\underline{5.9}-6.9 \mu \mathrm{m}, \mathrm{Q}=1.32-\underline{1.53}-$ $1.73(\mathrm{n}=20)$; ellipsoid or somewhat ovoid; weakly verrucose; moderately to rather strongly dextrinoid.

SPECIMEN EXAMINED: Cortinarius atomatus Bidaud ad int. France, Savoie, Bonneval-sur-Arc, cirque des Évettes, among Salix herbacea, alt. 2400 m, 31.VIII.1996 leg. M. Chiaffi, AB 96-08-36 (Herb. A. Bidaud). - Part of type as a loan. Spores 8.9- $\underline{9.6}-$ $11.0 \times 5.2-\underline{5.7}-6.3 \mu \mathrm{m}, \mathrm{Q}=1.43-\underline{1.70}-2.04(\mathrm{n}=20)$; ellipsoid to subamygdaloid, rarely more or less cylindrical or amygdaloid: rather weakly verrucose; weakly dextrinoid. Lamellar hyphae smooth.

OTHER SPECIMENS EXAMINED: FINLAND. Pohjois-Karjala. Nurmes, Joki-Vastimo, 2.IX.2002 Kokkonen 124/02, 18.IX.2003 Kokkonen 706/03, Metsä-Vastimo 31.VIII.2002 Kokkonen 125/02*, 131/02\%, 132/02*, 24.IX.2002 Kokkonen 123/02*, 23.IX.2003 Kokkonen 783/03* , Pahakala, 26.VIII.2002 Kokkonen 138/02, 16.IX.2002 Kokkonen 126/02, 27.VIII.2003 Kokkonen 251/03. Valtimo, Haapakylä, Heinälampi, 20.IX.2003 Kokkonen 737/03*, 762/03*\%, Mahalanniemi, 29.VIII.2002 Kokkonen 38/02*, 5.X.2003 Kokkonen 919/03*, mouth of Matkusjoki, 22.IX.2003 Kokkonen 797/03*, Kalliojärvi, 9.IX.2008 Kokkonen 285/08*, Liuhanniemi, 30.IX.2016 Kokkonen $618 / 16^{*}$. Koillismaa. Kuusamo, Huotinniemi, 11.IX.2012 Kokkonen 1230/12*, Oivanki, 13.VIII.2006 Kokkonen 137/06*. Salla, Kotala, 20.VIII.2008 Kokkonen 86/08* and J. Vauras. Kittilän Lappi. Kittilä, Sirkka, 16.VIII.2006 Kokkonen 178/06*. Enontekiön Lappi. Enontekiö, Palojoensuu, 19.VIII.2006 Kokkonen 260/06, Peltovuoma, 22.VIII.2006 Kokkonen 310/06*. Inarin Lappi. Utsjoki, Tsuomasvarri, near S. reticulata and S. herbacea, 27.VIII.2005 Kokkonen 515/05*. ICELAND. Suđur-ĺsland. Rangárping eystra, Valahnúkur, 16.IX.2017 Kokkonen 332/17*. 


\section{CORTINARIUS INOPS COMPLEX}

Figure 7

Fungi resembling $C$. inops J.Favre were remarkably variable genetically, despite a very similar morphology. Four groups were recognized. Cortinarius vernus H.Lindstr. \& Melot was one group. Three $C$. erythrinus collections belonged here, but they differed genetically from each other, and C. erythrinus also appeared to be outside this complex. The identity of C. erythrinus is unclear due to the lacking type. The fungi of this complex are characterized by a dark brown or black brown pileus, a pale grey or whitish fibrillose stipe, an occasional red base, and strongly verrucose ellipsoid spores. The stipe cover may have a violaceous tinge, and the lamellae are usually rather dark brown having sometimes a yellow or red tinge. No distinct morphological differences could be found among the groups. They were not found from boreal pure Salix thickets by lakes and rivers, but from inland mixed shore forests, among $S$. repens or S. phylicifolia on seashores, or with dwarf $S a$ lix in the alpine zone. They grow also in other mixed or deciduous forests and man-made habitats like parks in Finland. Several tree species seemed to be hosts, and the groups had some habitat differences.

Cortinarius inops J.Favre, Ergebn. Wiss. Unters. Schweiz. Natl. Parks 5 (33): 203 (1955), coll.

The sequence differences among the groups (Figs. 19,20 ) were $2-3$ bases and 1-3 indels by ITS, but as much as $8-15$ bases by RPB2 suggesting separate species. Favre (1955) described C. inops from the Swiss Alps. Its identity remained partially open due to the low quality of the type ITS2 sequence. Its ITS1 sequence was identical with three recent collections from the Alps, which are determined here as C. inops. The messy ITS2 chromatograms of the type were carefully edited, but the resulting deficient ITS2 sequence is somewhat uncertain. It deviated at least by 3 bases and several indels from the other three inops collections. Peculiarly, the deviating bases of the type were the same in a C. erythrinus collection from lowland Italy (Campo 2.VIII.2014), which collection was otherwise genetically distant. More sequenced collections will probably clear up the situation. It was a common feature within this complex that most base differences occurred in ITS2.

Favre described $C$. inops as having cheilocystidia, but cystidia did not appear as a good diagnostic character. The occurrence of cystidia varied within the groups. Also before, the occurrence of cystidia or sterile cells at the gill edge has varied intraspecifically a lot in Telamonia (Niskanen 2008). No cystidia were found in a small lamellar piece of the inops type. According to Horak (1987), cheilocystidia can not always be found from old inops specimens. Favre (1955) regarded the presence of cheilocystidia as a major difference between $C$. inops and $C$. tenebricus J.Favre. Two Swiss alpine collections deviating from the inops type at least by 5 bases and several indels (in Group 3, Fig. 19) had somewhat narrower spores, resembling thus the spore shape of $C$. tenebricus. However, their spores were as strongly ornamented as those of $C$. inops and had cheilocystidia, similarly to the recent Swiss inops collections. The type of $C$. tenebricus was examined morphologically (results under Additional examined types), but not sequenced.

The boreal " $C$. vernus" specimens were closer to $C$. inops than to $C$. vernus sequences judging by their ITS sequences. They were divided into two groups, which deviated by $2-3$ bases in ITS, but at least by 11 bases in RPB2 from each other, and probably represent separate species. Another RPB2 group was closer to $C$. vernus than to other $C$. inops coll. specimens. The groups had different habitats. Group 2 (Figs. 19, 20) occurred in various inland habitats from the hemiboreal to the subarctic zone, and Group 3 on seashores and in the alpine zone near Salix, also in the Alps. Two C. erythrinus specimens of N. Arnold from Germany belonged to Group 2 according to the ITS sequences. They were collected from a mixed forest or near Tilia. Contrary to Group 3, possibly none of the Group 2 fungi were connected with Salix. No morphological differences were observed between the groups. For example, red stipe base was observed in both groups, similarly to C. vernus. Group 2 sequences were identical with C. vernus var. nevadavernus Suár--Sant. \& A.Ortega specimens of Suárez-Santiago et al. (2009). They regarded the variety conspecific with $C$. vernus due to 


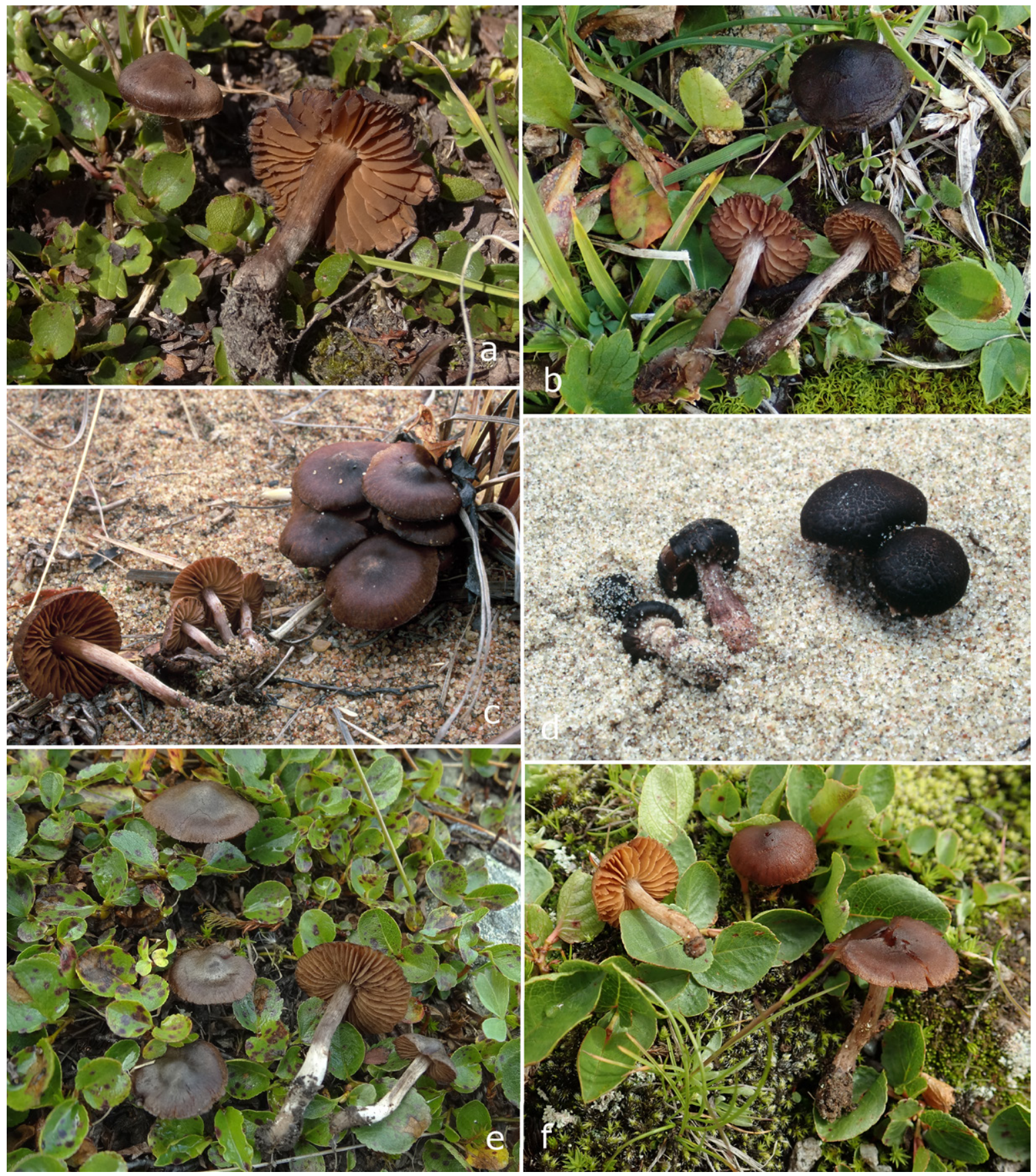

Fig. 7. Cortinarius inops complex. a C. inops. Switzerland, KK 292/17. b C. inops. Switzerland KK 68/19. c C. inops coll. Finland, Kalajoki, KK 255/04. d C. inops coll. Finland, Pietarsaari, KK 280/04. e C. inops coll. Sweden, KK 1395/16. f C. inops coll. Switzerland, KK 38/19. 
the similar morphology, but the variety lacked the aromatic smell of vernus and fruited only in spring. In contrast, the boreal and temperate Group 2 specimens fruited from spring to autumn.

LECTOTYPE: Cortinarius inops J.Favre. Switzerland, Graubünden, National Park, the upper part of Val dal Botsch, near Fuorn, alt. 2550 m, near dwarf willows, Triassic calcareous soil, 12.VIII.1953 J. Favre No ZA 155a (GK 13294a). - The specimen with 2 fruitbodies. Spores $6.5-\underline{7.3}-8.1 \times 4.9-\underline{5.4}-5.7 \mu \mathrm{m}$, $\mathrm{Q}=1.20-1.35-1.56(\mathrm{n}=20)$; ellipsoid, sometimes a slight suprahilar depression; strongly to very strongly verrucose; moderately to rather strongly dextrinoid. Cheilocystidia not observed.

OTHER SPECIMENS EXAMINED: C. INOPS: ITALY. Trento. Soraga, Passo della Selle, alpine area, among Salix retusa with Euphrasia minima, calcareous soil, 23. VIII.2006 E. Campo (TUR-A)*. Belluno. Marmolada - Rocca Pietore, alpine area, among S. retusa, calcareous soil, 3.VIII.2017 E. Campo (TUR-A)*. SWITZERLAND. Graubünden. Scuol, Val Plavna, alt. $2320 \mathrm{~m}$, among S. herbacea, 15.VIII.2017 Kokkonen 292/17*, Val S-charl, SW of Alp Astras, alt. $2365 \mathrm{~m}$, near $S$. retusa, $S$. reticulata and $S$. foetida, 27.VIII.2019 Kokkonen 68/19*. GROUP 2: FINLAND. Varsinais-Suomi. Koski Tl., Myllykylä, slope by the river, wood of cultivated Populus (poppeli), scattered Salix caprea and Betula, riverside Salix bushes, mainly clay soil, 30.V.2011 M.-L. and P. Heinonen 20-2011 (as C. vernus)*. Turku, Ruissalo, nature reserve, herb-rich forest with Populus tremula, Betula, Picea abies, Salix caprea and Quercus robur, 9.VIII.2007 Kokkonen 208/07 (as C. vernus)*. Pohjois-Karjala. Nurmes, Pahakala, moist shore forest with Salix bushes, Alnus, Betula and Picea, 27.VIII.2003 Kokkonen 277/03 (as C. vernus)*. Inarin Lappi. Utsjoki, Tsieskuljoki, 20.VIII.1965 leg. P. Kallio, symposioretkikunta, det. T. Niskanen and I. Kytövuori (as C. vernus)*. GERMANY. Bayern. Kürn, with Tilia, 10.VII.1988 N. Arnold 8/88 (REG 10916, as C. erythrinus)*. Saulburg, mixed forest, 10.X.1990 N. Arnold 31/90 (REG 10922, as C. erythrinus)*. GROUP 3: FINLAND. Keski-Pohjanmaa. Kalajoki, Hiekkasärkät, near Salix phylicifolia and Alnus, sandy soil, 10.IX.2004 Kokkonen 255/04\%. Kokkola, Lohtaja, Vattajaniemi, beach, among S. repens and Pinus sylvestris seedlings, 11.IX.2004 Kokkonen 265/04*. Pietarsaari, Fäboda, beach, near Salix phylicifolia, further away Alnus, Pinus and Betula, 12.IX.2004 Kokkonen 280/04\%. SWEDEN. Lule Lappmark. Gällivare, Nieras, among S. herbacea, 30.VIII.2016 Kokkonen 1395/16*. SWITZERLAND. Graubünden. Scuol, Lai Sesvenna, alt. $2660 \mathrm{~m}$, among S. herbacea, 17.VIII.2017 Kokkonen 281/17*, 25.VIII.2019 Kokkonen $38 / 19^{*}$.

\section{Cortinarius vernus $H$.Lindstr. \& Melot,} Cortinarius Flora Photographica 3: 27 (1994)

Cortinarius vernus type sequence (UNITE UDB000742, Suárez-Santiago et al. 2009) deviated at least by 7 bases and few indels from $C$. inops sequences of this study, which is why $C$. vernus is regarded here as a separate species despite similar morphology. However, four base substitutions were very close, possibly indicating a lower number of events. Both types were examined morphologically and had similar spores.

The type of $C$. vernus was collected among cultivated Abies sibirica in Sweden (Brandrud et al. 1994). The species was not among my boreal and alpine material. Instead, the type sequence was nearly identical with sequences of a $C$. erythrinus collection near Quercus in Germany and a Mediterranean $C$. castaneus var. monspeliensis collection near Cistus salviifolius and Pinus pinea in Italy. Consequently, C. vernus seems to be absent from the alpine zone and have different hosts than the usual boreal " $C$. vernus".

HOLOTYPE: Cortinarius vernus H.Lindstr. \& Melot. Sweden, Ångermanland, Hemsö, Drafle, cultivated park with Abies sibirica, 19.VIII.1986 leg. T. E. Brandrud, H. Lindström, H. Marklund and S. Muskos, CFP443 (S). - Spores 5.8- $\underline{6.9}-8.1 \times 4.5-$ 5.0-6.0 $\mu \mathrm{m}, \mathrm{Q}=1.13-\underline{1.40}-1.68 \quad(\mathrm{n}=20)$; ellipsoid, often a slight suprahilar depression; strongly to very strongly verrucose; rather strongly to strongly dextrinoid. Cheilocystidia not observed.

OTHER SPECIMENS EXAMINED: GERMANY. Bayern. Bamberg, Hain, with Quercus, alt. ca. 240 m, 24.IX.1990 N. Arnold 7/90 (REG 10927, as C. erythrinus)*. ITALY. Grosseto. Bosco di Patanella-Orbetello, near Cistus salviifolius and Pinus pinea, 4.XI.2016 E. Campo (TUR-A, as C. castaneus var. monspeliensis)*. 


\section{CORTINARIUS PARVANNULATUS COMPLEX}

Cortinarius parvannulatus Kühner, Bull. Mens. Soc. Linn. Lyon 24(2): 40 (1955)

Cortinarius cedriolens M.M.Moser, Kleine

Kryptogamenflora 2b/2: 337 (1967)

Cortinarius rufoanuliferus M.M.Moser \&

McKnight, Arctic Alpine Mycol. 2: 314 (1987)

Cortinarius parvannulatus occured rather commonly in boreal moist Salix thickets, as well as in the alpine zone with dwarf Salix. The identifications based on the description of Funga Nordica (Niskanen et al. 2012b). Much genetic and micromorphological variation was observed, which probably indicates the presence of multiple species, as already noted by Esteve-Raventós et al. (2014). Four small groups were formed by ITS, in addition to the clades with a single specimen (Fig. 19). A sequence of $C$. cedriolens from GenBank (AY083179, Peintner et al. 2003), along with identical sequences with it, belonged to the variation. The type of $C$. rufoanuliferus had an identical sequence with C. cedriolens, why C. rufoanuliferus may be a synonym of $C$. cedriolens. These species also have a similar morphology, except $C$. rufoanuliferus lacked a specific smell (Moser 1967, Moser \& McKnight 1987). Cortinarius cedriolens has sometimes been treated as a synonym of $C$. parvannulatus (e.g. Suárez-Santiago et al. 2009) but not in this study, since their types were not examined. The clades deviated from each other mostly by one or two bases in the ITS sequence and possessed similar morphologies, requiring more specimens and DNA regions to be examined to resolve species limits within this complex. The tentative RPB2 results supported the separation of ITS clades, but the specimens or groups were differently related in the phylogenetic trees. A specimen was closer to $C$. pseudofallax than other parvannulatus specimens in the RPB2 tree. Unfortunately, several RPB2 analyses of C. parvannulatus specimens yielded poor chromatograms and were excluded.

As with other species complexes of this study, the presence of different genotypes having somewhat dissimilar morphologies within a site probably indicates separate species. The morphological differ- ences between the clades were more distinct within sites than among the whole groups. For example, a collection in Group 3 had larger spores compared with a Group 1 collection from the same site concerning two sites, while the spore sizes did not much differ between all collections of these groups. The average spore widths separated groups better than the spore lengths. For example, the mean spore size was $6.8-7.8 \times 4.4-4.7 \mu \mathrm{m}$ in Group $1(\mathrm{n}=4)$ and $7.4-8.2$ $\times 4.8-5.1 \mu \mathrm{m}$ in Group $3(\mathrm{n}=5)$, and the site-specific differences were $6.8 \times 4.7 \mu \mathrm{m}$ versus $8.2 \times 5.0 \mu \mathrm{m}$ and $7.4 \times 4.5 \mu \mathrm{m}$ versus $7.7 \times 4.8 \mu \mathrm{m}$. The mean spore size in Group 2 was at the larger end: 8.0-8.7 $\times 5.3-5.5$ $\mu \mathrm{m}(\mathrm{n}=3)$. There appeared also some other slight micromorphological differences among the clades. The spores were rather strongly or strongly verrucose in Group 2, but rather weakly to moderately verrucose in Group 3, and varied from weakly to strongly verrucose in Group 1. The spores were usually ellipsoid, but especially Group 3 specimens had also obtusely amygdaloid spores. All specimens had moderately to strongly dextrinoid spores, except the separate Icelandic specimen and the rufoanuliferus type had rather weakly dextrinoid spores.

Fungi belonging to the C. parvannulatus complex are usually easily recognized by the smell of cedar wood and red brown, orange, or yellow brown fruitbodies. In this study, the stipe had occasionally a violet tinge especially at apex and/or a white ring irrespective of the clade. However, the ring seemed to be more characteristic for Group 1, since all specimens were observed with rings. In addition, all specimens of the cedriolens clade lacked rings. The groups may have habitat differences as well. The two boreal collections of Group 2 grew in eutrophic fens, while others by lakes or brooks, or once in a pastured forest. One site of Group $3 \mathrm{had}$ no other trees than Salix nearby, but other sites often included scattered Betula.

HOLOTYPE: C. rufoanuliferus M.M.Moser \& McKnight. USA, Wyoming, Yellowstone National Park, Mt. Washburn, timberline, alt. 3300 m, Picea engelmannii and Salix sp. (herbacea-like), 27.VIII.1983 leg. M. Moser, det. M. Moser and K. McKnight (IB 1983/0342). - Part of type as a loan. Spores 6.9-7.7-8.4 x 4.9- $\underline{5.4}-5.8 \mu \mathrm{m}, \mathrm{Q}=1.27-$ 1.42-1.58 ( $\mathrm{n}=20)$; ellipsoid; weakly verrucose; rather weakly or weakly dextrinoid. 
OTHER SPECIMENS EXAMINED: FINLAND. Pohjois-Häme.Laukaa, 12.IX.2002 Kokkonen 127/02*. Pohjois-Karjala. Nurmes, Metelinmäki, 23.IX.2002 Kokkonen 46/02*, Metsä-Vastimo, 15.VIII.2002 Kokkonen 130/02*, Pahakala, 27.VIII.2003 Kokkonen 239/03*, 15.IX.2003 Kokkonen 618/03*. Valtimo, Kalliojärvi, 9.IX.2008 Kokkonen 284/08*. Kainuu. Kuhmo, near Koirakangas, 8.IX.2018 Kokkonen $817 / 18^{*}, 818 / 18^{*}$. Kittilän Lappi. Kittilä, near the main village, 28.VIII.2008 Kokkonen 438/08*. Sompion Lappi. Pelkosenniemi, E of Akanvaara, nature reserve, 20.VIII.2009 Kokkonen 99/09* and J. Vauras. Savukoski, Ainijärvi, 21.VIII.2008 Kokkonen 105/08* and J. Vauras. Inarin Lappi. Locality unknown, likely Utsjoki, VIII.1965 M. Lange (as cf. C. pauperculus)*. ICELAND. Suđur-ĺsland. Rangárping eystra, Valahnúkur, near S. herbacea, S. arctica and Betula, 16.IX.2017 Kokkonen 356/17*, 358/17*. SWEDEN. Lule Lappmark. Gällivare, Nieras, near S. herbacea, 30.VIII.2016 Kokkonen 1404/16*. SWITZERLAND. Graubünden. Scuol, Val S-charl, Valbella, alt. 2215 m, near S. reticulata and Dryas octopetala, further away Pinus, 26.VIII.2019 Kokkonen 52/19*.

\section{Cortinarius croceocingulatus N.Arnold \& E.Ludw., Libri Botanici 7: 104 (1993)}

A group of four boreal specimens deviating by 4 bases and 3 indels from most C. parvannulatus specimens were identified as C. croceocingulatus based on literal descriptions (Arnold 1993, Niskanen et al. 2012b). The specimens differed from C. parvannulatus by squamulose or fibrillose pilei and indextrinoid or weakly dextrinoid spores. The colour of the veil was brownish, when noted once. Young fungi had a violet tinge at stipe apex. Cortinarius croceocingulatus was described growing with Salix in Swedish Lapland (Arnold 1993). All my collections originated from the northern boreal zone of Finland. They grew by rivers near Salix phylicifolia, S. lapponum or S. glauca, and also near Alnus inca$n a$ or a mixed forest at two sites. The spores were rather weakly to moderately verrucose, ellipsoid to subamygdaloid, and varied by mean size among the collections: $7.7-8.9 \times 4.7-5.4 \mu \mathrm{m}(\mathrm{n}=4)$. An arctic collection from Svalbard was conspecific deviating only by one indel from the others. It was originally determined as C. phaeopygmaeus J.Favre. According to the descriptions of Favre (1955) and Horak (1987), C. phaeopygmaeus lacks the smell of cedar wood and the spores are larger, why the specimen was probably misidentified. Another conspecific specimen from Svalbard has been published in BOLD database (NOBAS2354-16.ITS). It was determined as $C$. parvannulatus.

SPECIMENS EXAMINED: FINLAND. Koillismaa. Kuusamo, Oulanka National Park, near Nurmisaarenrinne, 9.IX.2012 Kokkonen 1329/12*. Kittilän Lappi. Kittilä, Köngäs, 15.VIII.2006 Kokkonen 167/06*. Sompion Lappi. Savukoski, Värriöjoki, 18.VIII.2019 Kokkonen 11/19*. Enontekiön Lappi. Enontekiö, Palojoensuu, 19.VIII.2006 Kokkonen 244/06* NORWAY. Svalbard. Vestspitsbergen, Ny Ålesund, dry tundra heath, 11.VIII.1988 leg. E. Ohenoja, det. D. Lamoure (as C. phaeopygmaeus)*.

\section{Cortinarius neofallax Carteret \& Reumaux,} Atlas des Cortinaires 14: 907 (2004)

Cortinarius pseudofallax Carteret, Atlas des Cortinaires 14: 907 (2004)

Two species published as close to C. parvannulatus, C. neofallax and C. pseudofallax, were also found in this study. They were identified by comparing to the type sequences in GenBank (KF048129, NR131831, Esteve-Raventós et al. 2014). Both species had different habitats, and likely different hosts, than the usual Salix bushes of C. parvannulatus in this study. They deviated only by 2-3 bases in ITS from $C$. parvannulatus, and their RPB2 sequences, especially of C. pseudofallax, were among the variation of parvannulatus sequences, why they could belong to $C$. parvannulatus.

Cortinarius pseudofallax has been published from Fennoscandia growing with Salix caprea and some other trees (Esteve-Raventós et al. 2014, Brandrud et al. 2015). The single pseudofallax collection of this study also grew near $S$. caprea, together with Betula and Picea. Its habitat was a brookside in a Picea abies -dominated forest in the southern boreal zone. It had a violet stipe apex and small ellipsoid spores, ca. $6.5-7.5 \times 4-4.5 \mu \mathrm{m}$, similarly to the previous reports (Bidaud et al. 2004, Esteve-Raventós et al. 2014, Brandrud et al. 2015). The spores were rath- 
er strongly verrucose and dextrinoid.

Cortinarius neofallax was found from two moist sites with rich vegetation from the southern and middle boreal zones. One collection grew among e.g. Filipendula ulmaria, Geranium sylvaticum and Rosa majalis in a mixed shore forest by a lake and another among Athyrium filix-femina ferns by a brook. The lakeside forest included scattered Salix, while only Picea, Alnus, Populus and Betula were observed by the brook. Carteret and Reumaux described C. neofallax growing with hygrophilous broad-leaved trees, and Betula pendula was dominant at one site (Bidaud et al. 2004). Macroscopically, my collections did not differ notably from $C$. parvannulatus. The spores were rather narrowly amygdaloid to ellipsoid, rather strongly verrucose, and moderately dextrinoid. The mean spore sizes of the specimens were $7.3 \times 4.4 \mu \mathrm{m}$ and $8.0 \times 4.9 \mu \mathrm{m}$.

SPECIMENS EXAMINED: C. neofallax: FINLAND. Pohjois-Savo. Kuopio, Nilsiä, Pieni-Tarpinen nature reserve, shore forest, near Picea abies, Betula, Pinus sylvestris and a Salix myrsinifolia-phylicifolia hybrid, 22.IX.2008 Kokkonen 409/08*. Kainuu. Paltamo, Kivesvaara-Keräsenvaara nature reserve, 29.IX.2018 Kokkonen 819/18*. C. pseudofallax: FINLAND. Pohjois-Savo. Kuopio, Puijo, 12.IX.2016 Kokkonen $531 / 16^{*}$.

\section{CORTINARIUS PAUPERCULUS COMPLEX}

Figure 8

Cortinarius pauperculus has not been recorded from Fennoscandia before. In this study, two boreal collections from the same locality had identical ITS sequences with the type, and several morphologically similar collections deviated genetically slightly from the type. All resembled morphologically Favre's (1955) description of C. pauperculus from the Swiss Alps. Most collections formed two groups. Since both groups occurred at three same sites, where they had slight morphological and genetic differences, they are described as new species.
Cortinarius pauperculus J.Favre, Ergebn. Wiss. Unters. Schweiz. Natl. Parks 5 (33): 203 (1955)

Cortinarius pauperculus is a small species. The two boreal collections genetically identical with the type had pileus diameters $3.5-7 \mathrm{~mm}$ and stipe sizes $10-$ $17 \times 0.7-1 \mathrm{~mm}$. The whole fruitbodies were rather dark red brown. The pileus was conical as young and later applanate with an acute papilla. A young fruitbody had a pale fibrillose margin. The lamellae were distant and adnate. The stipe was delicately silky fibrillose having some whitish veil in the lower part. They were odourless. The specimens were collected from a sandy riverbank in a canyon near Salix phylicifolia and Alnus incana in the northern boreal zone. A single fruitbody from the Swiss Alps was genetically identical. It was also small, and the pileus had a papilla, but other notes as fresh lacked. According to Favre (1955), the pileus diameter of $C$. pauperculus extends to $16 \mathrm{~mm}$ and the stipe length up to $23 \mathrm{~mm}$. The RPB2 sequences of the Finnish and Swiss collections were identical, but the Finnish sequence included several ambiguous bases.

The spore sizes of the boreal collections were near the type spore size: $7.0-\underline{8.4}-9.8 \times 4.6-\underline{5.4}-$ $5.9 \mu \mathrm{m}$, range of mean values $8.1-8.6 \times 5.3-5.4 \mu \mathrm{m}$, $\mathrm{Q}=1.40-1.57-1.73$, range of mean $\mathrm{Q}$ values $1.53-$ 1.60 ( 20 spores from 2 collections). The spores were ellipsoid with an occasional suprahilar depression, moderately verrucose, and moderately to rather strongly dextrinoid. The lamellar hyphae had rather strong or strong incrustations and dark flecks. The spores of the Swiss collection were rather similar with mean size $8.3 \times 5.1 \mu \mathrm{m}$ and mean Q value 1.63. They were rather strongly verrucose.

LECTOTYPE: Cortinarius pauperculus J.Favre. Switzerland, Graubünden, Val Sesvenna, alt. 2550 m, near S. charl, 24.VIII.1943 J. Favre 159a (GK 13303). Specimen with ca. 20 fruitbodies in good condition. Spores 7.5- $\underline{8.5}-10.3 \times 5.0-\underline{5.5}-6.1 \mu \mathrm{m}, \mathrm{Q}=1.36-$ $\underline{1.56}-1.75(\mathrm{n}=20)$; ellipsoid or somewhat cylindrical; rather weakly verrucose, somewhat more strongly verrucose at apex, at times 1-2 large verrucae at apex; rather weakly to moderately dextrinoid.

OTHER SPECIMENS EXAMINED: FINLAND. Koillismaa. Posio, Korouoma nature reserve, 14.VIII.2006 Kokkonen 157/06*, 19.IX.2019 Kokko- 


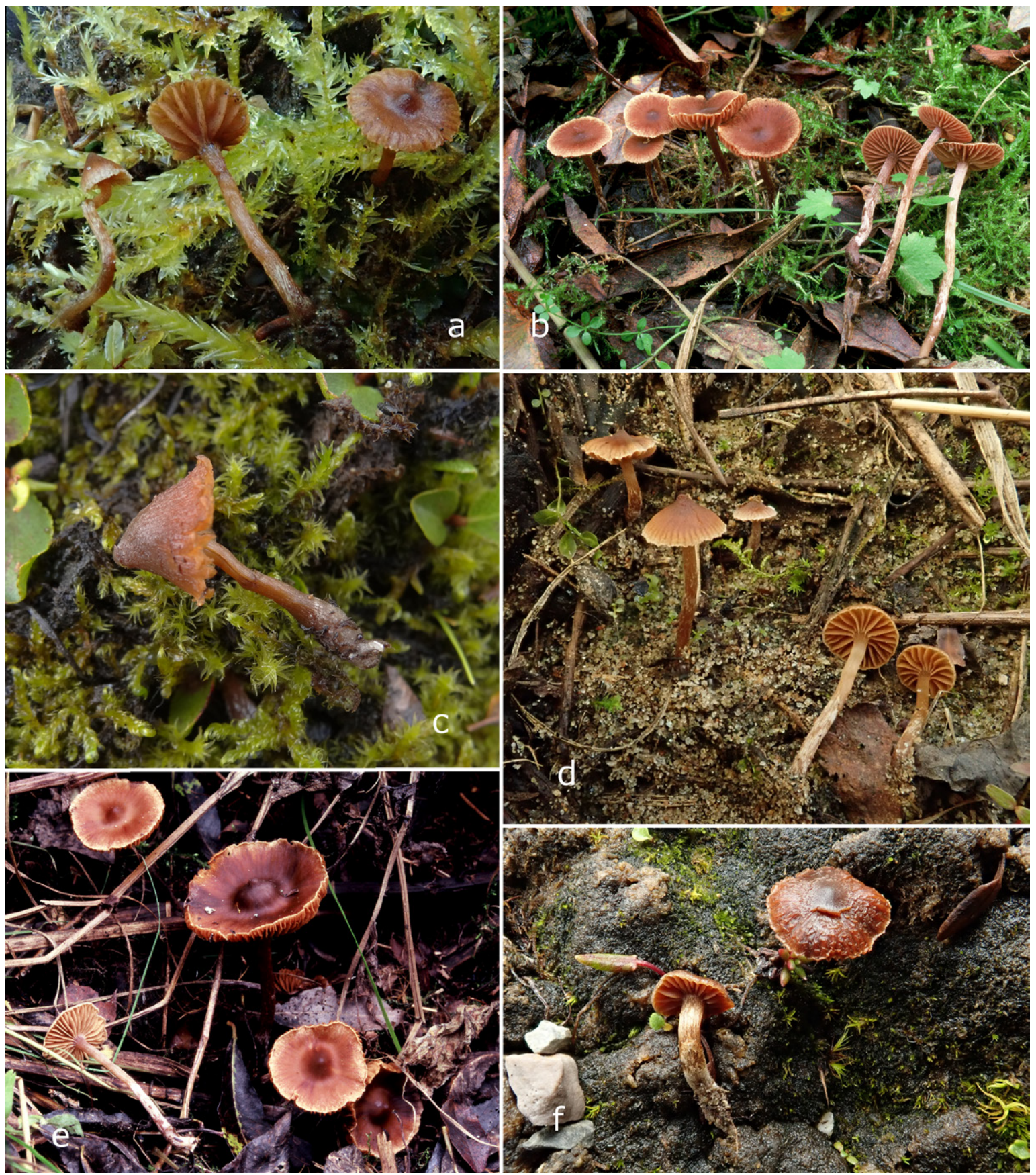

Fig. 8. Cortinarius pauperculus complex. a C. pauperculus. Finland, Posio, KK 101/19.

b C. paululus. Finland, Valtimo, holotype. c C. paululus. Switzerland, KK 305/17.

d C. paululus. Finland, Kuusamo, KK 99/19. e C. paulus. Finland, Valtimo, holotype.

f C. scotoides. Switzerland, KK 47/19. 
nen 101/19*. SWITZERLAND. Graubünden. Scuol, Lai Sesvenna, alt. 2665 m, near Salix herbacea, 17.VIII.2017 Kokkonen 285/17*.

\section{Cortinarius paululus Kokkonen, sp. nov.}

Figures $8 b-d$ and $9 a$

$$
\text { MycoBank MB833742 }
$$

ETYMOLOGY: paululus (Latin) refers to the small size, similarly to pauperculus; smaller than C. paulus.

HOLOTYPE: Finland, Pohjois-Karjala, Valtimo, Haapakylä, Heinälampi, shore of a pond connected to river, Salix thicket with $S$. phylicifolia and S. myrsinifolia, scattered Betula and Alnus incana, 3.IX.2003 K. Kokkonen 414/03 (TUR; isotypes G, IB), ITS MN841176, RPB2 MN808008.

PILEUS diameter 4-20 $\mathrm{mm}$; low convex, applanate, campanulate, or conical, often with an acute or obtuse umbo or papilla; young dark brown, then red brown, ochraceous brown, or dark brown $\left(\mathrm{S}_{70} \mathrm{Y}_{90}\right.$ $\left.{ }_{99} \mathrm{M}_{70}, \mathrm{~S}_{60} \mathrm{Y}_{40} \mathrm{M}_{50}\right)$, centre darker and often blackish, margin paler; smooth or delicately fibrillose especially at margin, at times margin fringy; hygrophanous, translucently striate. LAMELLAE up to $3 \mathrm{~mm}$ broad; adnate or emarginate, moderately crowded to distant; rather dark brown to dark brown $\left(\mathrm{S}_{60} \mathrm{Y}_{40} \mathrm{M}_{50}\right.$, $\left.\mathrm{S}_{60} \mathrm{Y}_{60-70} \mathrm{M}_{50}\right)$ or yellowish brown $\left(\mathrm{S}_{50} \mathrm{Y}_{90} \mathrm{M}_{50}, \mathrm{~S}_{50} \mathrm{Y}_{99} \mathrm{M}_{60}\right)$; edge even and usually paler. STIPE slender, 8-56 $\mathrm{mm}$ long, $0.8-2.5 \mathrm{~mm}$ wide; equal or widening slightly downwards; somewhat paler than pileus or concolorous with it, at times darkening towards base, rarely violaceous tinge at apex; delicately silky fibrillose, especially lower part with white or whitish veil cover or slightly flocculose. CONTEXT concolorous with surface, or dark brown at pileus and yellow brown at stipe. CORTINA whitish. SMELL not distinctive or rarely weakly pelargonious.

SPORES $6.9-\underline{8.4}-10.1 \times 4.5-\underline{5.1}-6.0 \mu \mathrm{m}$, range of mean values $7.9-9.1 \times 4.7-5.4 \mu \mathrm{m}$, $\mathrm{Q}=1.42-1.66-2.02$, range of mean $\mathrm{Q}$ values $1.56-$ 1.79 (250 spores from 15 collections); ordinary or narrow ellipsoid, occasionally subamygdaloid or cylindrical in some collections, suprahilar depression rare to frequent; rather weakly to strongly verrucose, usually rather strongly verrucose, verrucae mostly larger at apex; usually moderately dextrinoid, rarely rather weakly dextrinoid. LAMELLAR HYPHAE usually strongly encrusted, at times with dark narrow flecks. PILEIPELLIS hyphae $2-32 \mu \mathrm{m}$ wide, brownish or hyaline, mostly strongly or very strongly coarsely encrusted, often with dark red brown flecks.

HABITAT AND DISTRIBUTION: boreal Salix thickets or shore forests by lakes, rivers and sea, alpine zone near dwarf Salix; collections from the transition between the southern and middle boreal zones to the northern boreal zone in Finland and from the alpine zone in Switzerland. Salix is probably the only host. Salix phylicifolia and S. lapponum were the only tree species at one boreal site. Soil varies from muddy to sand. Rather common in Salix thickets of eastern and northern Finland.

SPECIMENS EXAMINED: FINLAND. Keski-Pohjanmaa. Kalajoki, Hiekkasärkät, seashore, near Salix phylicifolia and Alnus incana, 9.IX.2004 Kokkonen 236/04*. Pohjois-Karjala. Nurmes, Joki-Vastimo, 18.IX.2003 Kokkonen 696/03*, Pahakala 15.IX.2003 Kokkonen 626/03*, 29.VIII.2009 Kokkonen 143/09*. Valtimo, Haapakylä, Heinälampi, 24.IX.2002 Kokkonen 44/02*, 3.IX.2003 Kokkonen 414/03 (holotype)*, 415/03*, Mahalanniemi, 6.IX.2003 Kokkonen 460/03*. Perä-Pohjanmaa. Kemijärvi, Vuostimo, 23.VIII.2005 Kokkonen 487/05*. Koillismaa. Kuusamo, Oulanka National Park, Jäkälämutka, 17.IX.2019 Kokkonen 87/19*, 92/19*, 93/19*, SW of Nurmisaarenrinne, 18.IX.2019 Kokkonen 97/19*, 99/19*, Vuotunki, 31.VIII.2007 Kokkonen 539/07*, 568/07* and J. Vauras. Salla, Kotala, 20.VIII.2008 Kokkonen 95/08* and J. Vauras. Kittilän Lappi. Kittilä, Sirkka, 16.VIII.2006 Kokkonen $177 / 06 *$. Enontekiön Lappi. Enontekiö, Kaaresuvanto, 20.VIII.2006 Kokkonen 266/06*. SWITZERLAND. Graubünden. Scuol, Val Sesvenna, alt. 2525 m, near S. herbacea, 14.VIII.2017 Kokkonen 305/17*.

COMMENTS: Cortinarius paululus deviated from $C$. pauperculus type by 4 bases, and from $C$. paulus 3-4 bases and 1-2 indels in ITS. Intraspecifically, two collections including the type had an insertion of two bases compared with the others. In RPB2, it deviated from the recent Swiss C. pauperculus collection at least by 7 bases and from $C$. paulus at least by 5 bases. Cortinarius paululus resembles morphologically $C$. pauperculus. The material of $C$. pauperculus is too scarce for a detailed morphological comparison. The fruitbodies of both species from sandy river shores appeared similar, but they 

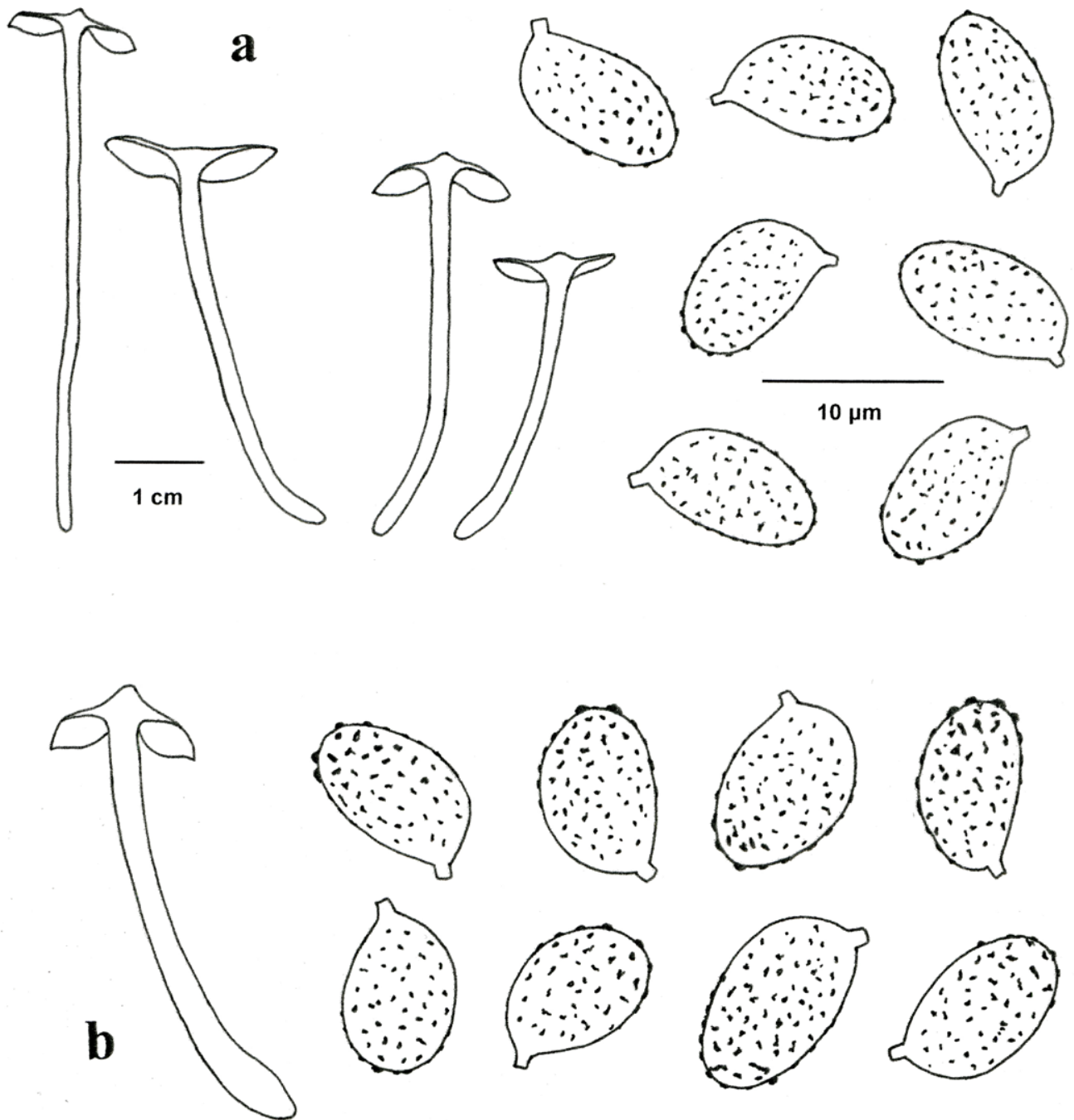

Fig. 9. a Cortinarius paululus. Holotype: second cross-section of fruitbody from the left, spores. KK 415/03: fruitbody on the left. KK 143/09: fruitbodies on the right. b Cortinarius paulus. Holotype: spores. KK 413/03: cross-section of fruitbody.

never grew at the same sites and probably have different requirements. Cortinarius pauperculus was notably rarer. The sole boreal pauperculus location was in a special habitat, a canyon. When compared with C. paulus, which occurred at the same sites as C. paululus, the fruitbodies of C. paululus were on average smaller, particularly had thinner stipes, and had mostly smaller and especially narrower spores. The collection from the Swiss Alps grew rather near the pauperculus collection in the valley of the pauperculus type. It had an acutely conical pileus and whitish veil at stipe (Fig. 8c). Lamoure (1977) described a small alpine species, C. galerinoides, which differed from C. pauperculus by paler pileus, scarcer 
veil and smaller spores. The description of $C$. galerinoides resembles $C$. paululus, but the ITS sequence of the galerinoides type was close to the $C$. helobius sequences.

\section{Cortinarius paulus Kokkonen, sp. nov.}

\section{MycoBank MB833743}

Figures $8 \mathrm{e}$ and $9 \mathrm{~b}$

HOLOTYPE: Finland, Pohjois-Karjala, Valtimo, Kalliojärvi, south side of Lake Kalliojärvi, Salix thicket with scattered Betula and Alnus incana, 14.IX.2008 K. Kokkonen 314/08 (TUR; isotype G), ITS MN841185, RPB2 MN808013.

PILEUS diameter $8-37 \mathrm{~mm}$; young conical, then campanulate, low convex, or applanate, usually with an acute umbo or papilla; red brown, ochraceous brown or dark brown $\left(\mathrm{S}_{40} \mathrm{Y}_{70} \mathrm{M}_{50}, \mathrm{~S}_{50} \mathrm{Y}_{90} \mathrm{M}_{60}\right.$, $\mathrm{S}_{60} \mathrm{Y}_{50} \mathrm{M}_{50}, \mathrm{~S}_{60} \mathrm{Y}_{70} \mathrm{M}_{60}, \mathrm{~S}_{70} \mathrm{Y}_{80} \mathrm{M}_{50}, \mathrm{~S}_{80} \mathrm{Y}_{60} \mathrm{M}_{50}$ ), at times centre darker; delicately fibrillose at margin or rarely overall, at times margin fringy or with scarce veil remnants; hygrophanous, translucently striate. LAMELLAE up to $5 \mathrm{~mm}$ broad; adnate or emarginate, moderately crowded to distant; concolorous with pileus, or slightly paler, or slightly more yellow$\operatorname{ish}\left(\mathrm{S}_{40} \mathrm{Y}_{70} \mathrm{M}_{50}, \mathrm{~S}_{50} \mathrm{Y}_{90} \mathrm{M}_{60}, \mathrm{~S}_{70} \mathrm{Y}_{80} \mathrm{M}_{50}\right)$; edge paler or concolorous. STIPE $23-73 \mathrm{~mm}$ long, $1.5-5 \mathrm{~mm}$ wide; equal, or narrowing or slightly widening downwards; somewhat paler than pileus or concolorous with it, at times darkening towards base, rarely violaceous tinge at base; delicately silky fibrillose, lower part usually with white or whitish veil cover or flocculose, at times a band. CONTEXT concolorous with surface, or dark brown at pileus and yellow brown at stipe. CORTINA whitish. SMELL not distinctive.

SPORES $8.0-\underline{9.1}-11.3 \times 4.9-\underline{5.7}-6.5 \mu \mathrm{m}$, range of mean values $8.9-9.7 \times 5.5-6.0 \mu \mathrm{m}$, $\mathrm{Q}=1.32-\underline{1.60}-2.14$, range of $\mathrm{Q}$ values $1.52-1.67$ (180 spores from 9 collections); usually ordinary ellipsoid, at times frequently narrow ellipsoid, rarely subamygdaloid or cylindrical in some collections, suprahilar depression usually occasional; rather strongly to strongly verrucose, rarely moderately verrucose, verrucae mostly larger at apex; moderately to rather strongly dextrinoid. LAMELLAR HYPHAE usually rather strongly to strongly encrusted, at times with dark flecks. PILEIPELLIS hyphae
2-32 $\mu \mathrm{m}$ wide, brownish or hyaline, mostly rather strongly or strongly coarsely encrusted, at times with dark red brown flecks.

HABITAT AND DISTRIBUTION: boreal Salix thickets or shore forests by lakes and rivers; collections from the transition between the southern and middle boreal zones to the northern boreal zone in Finland. Salix is probably the only host. Salix phylicifolia, S. myrsinifolia and S. pentandra were the only tree species at one site.

SPECIMENS EXAMINED: FINLAND. Pohjois-Karjala. Nurmes, Metsä-Vastimo, 23.IX.2003 Kokkonen 774/03*, Pahakala, 15.IX. 2003 621/03*, 6.X.2003 Kokkonen 971/03*, Saramo, 29.IX.2003 Kokkonen 854/03*. Valtimo, Haapakylä, Heinälampi, 3.IX.2003 Kokkonen 413/03*, 20.IX.2003 Kokkonen 751/03*, Mahalanniemi, 19.IX.2002 Kokkonen 36/02*, 30.IX.2016 Kokkonen 617/16*, Kalliojärvi, 14.IX.2008 Kokkonen 314/08 (holotype)* Perä-Pohjanmaa. Rovaniemi, Vikajärvi, 24.VIII.2007 J. Vauras and Kokkonen 453/07*.

Comments: Cortinarius paulus had usually larger fruitbodies and spores compared with $C$. pauperculus and C. paululus. The most distinct difference was in the mean spore width. Cortinarius paulus deviated from the pauperculus type by 4-5 bases and one indel in ITS, and at least by 8 bases in RPB2 from the recent Swiss pauperculus collection. A collection (KK854/03) deviated by one base from the other paulus collections in ITS, but since it was morphologically similar and had a mixed peak in the deviating position in one chromatogram, it was regarded as conspecific but excluded from the description. Cortinarius pauperculoides MoënneLocc. ad int. (Bidaud et al. 2012) is morphologically rather similar with C. paulus and C. paululus, and it was found to be genetically close, as explained below. Cortinarius helobius Romagn. as described by Romagnesi (1952) and Bendiksen et al. (1993) seems similar, but according to the C. helobius of Cortinarius Flora Photographica (Brandrud et al. 1994, Lindström et al. 2008, GenBank DQ102686) and an examined C. helobius collection of P. Moënne-Loccoz from France (Bidaud et al. 1991), it is a distant species. C. sphagnicola Carteret \& Reumaux has also similar morphology and habitat, but it was distant according to the type study. Three species that M. Moser (1993) described from North America grow- 
ing with Salix, C. expallens, C. ferrugineifolius and C. paraphaeochrous, resemble especially $C$. paulus, but they were distant according to the unpublished type sequences received from Ursula Peintner. A GenBank sequence of $C$. laetissimus Rob.Henry specimen from Canada (GQ159898, Harrower et al. 2011) deviated from $C$. paulus by 1-2 bases and an indel as well as from $C$. paululus by 2 bases. According to the protologue (Henry 1957), C. laetissimus differs by smaller and wider spores, a fruity smell, and the habitat in montane Picea forests. It was described from France.

Cortinarius scotoides J.Favre, Ergebn. Wiss. Unters. Schweiz. Natl. Parks 5 (33): 204 (1955)

Cortinarius scotoides was not found from the boreal zone, but only from the alpine zone in Switzerland, from where Favre (1955) described it. However, it occurs in the temperate zone, since C. pauperculoides Moënne-Locc. ad int. (Bidaud et al. 2012) appeared conspecific. Cortinarius pauperculoides was collected under Populus nigra from an abandoned quarry in France. The ITS sequence of an alpine scotoides collection was identical with the pauperculoides sequence excluding two ambiguous bases, and two other scotoides collections differed by one base and a deletion. The difference from $C$. pauperculus was only 2 bases and 3-4 indels in ITS, but up to 17 bases in RPB2 sequences. The scotoides RPB2 sequences deviated as much as 8 bases and an indel from each other. From C. paululus and C. paulus, the difference was 6-7 bases and 4-5 indels in ITS.

Cortinarius scotoides and C. pauperculoides were described to have smaller spores than C. pauperculus (Favre 1955, Horak 1987, Bidaud et al. 2012), but the spore sizes were found to be about the same with range of mean values $7.9-8.2 \times 4.7-5.4 \mu \mathrm{m}$ (50 spores from 4 collections). The spores of $C$. scotoides were often narrower with mean $Q$ value $1.68-1.73$. The spores were moderately to strongly verrucose and weakly or rather weakly dextrinoid. The Swiss fungi had a convex, applanate, or obtusely conical pileus without umbo or only with a small low umbo unlike the French pauperculoides and the other species of this complex. The pilei of the specimens de- viating by one base were cracked to squamules or rugulose (Fig. 8f). Cortinarius scotoides was identified by comparing my collections from a scotoides collection site of Favre with the descriptions of Favre (1955) and Horak (1987), as well as comparing the sequences with scotoides sequences of Hyde et al. (2019), where a new species C. subscotoides Niskanen \& Liimat. was described.

SPECIMEN EXAMINED: Cortinarius pauperculoides Moënne-Locc. ad int. France, Haute-Savoie, Rumilly, alt. 350 m, 13.V.1991 P. Moënne-Loccoz, PML 2176 (Herb. P. Moënne-Loccoz). - A fruitbody as a loan. Spores $6.9-\underline{7.9}-9.0 \times 4.4-\underline{4.7}-5.0 \mu \mathrm{m}$, $\mathrm{Q}=1.47-1.68-1.89 \quad(\mathrm{n}=20)$; mostly ellipsoid, occasionally subamygdaloid; moderately verrucose; weakly dextrinoid. Lamellar hyphae strongly encrusted.

OTHER SPECIMENS EXAMINED: SWITZERLAND. Graubünden. Scuol, Val Plavna, alt. 2255 m, near Salix reticulata and Dryas, 12.IX.2018 Kokkonen 833/18*, Val S-charl, Valbella, alt. 2180-2185 m, near S. reticulata and S. retusa, 26.VIII.2019 Kokkonen 41/19, near S. reticulata or S. herbacea, 26.VIII.2019 Kokkonen 42/19*, 43/19, 45/19, 47/19*.

\section{Cortinarius minusculus Liimat. \& Niskanen, Fungal Diversity 96: 182 (2019)}

Cortinarius minusculus was recently described from hemiboreal and temperate mixed forests without Salix (Hyde et al. 2019). In this study, it was found from a riverside Salix thicket with scattered Betula and Alnus in the transition zone between the southern and middle boreal zones of Finland, and from subarctic Iceland. The two Icelandic collections grew in a dry Betula pubescens forest with scattered Salix. Another of them grew among Empetrum nigrum. The species seems to be connected at least with Betula. The morphology of my collections resembled the protologue description, but the fruitbodies were on average larger. The pilei of the Finnish fruitboides reached $28 \mathrm{~mm}$ and the stipe width $3.5 \mathrm{~mm}$. The spores of the Icelandic collections were somewhat wider, ca. $7.5-10 \times 5-6 \mu \mathrm{m}$. The species deviated by $8-10$ bases, an inversion and two indels from C. pauperculus.

SPECIMENS EXAMINED: FINLAND. Pohjois- 
Karjala. Nurmes, Joki-Vastimo, 18.IX.2003 Kokkonen 698/03*. ICELAND. Suđur-l̂́sland. Rangárping eystra, Básar, near Betula and Salix phylicifolia, 14.IX.2017 Kokkonen 326/17*, Snorraríki, near Betula and S. phylicifolia, 13.IX.2017 Kokkonen 327/17*\%

\section{Additional specimens}

Two collections were genetically intermediate between C. paululus and C. paulus, and they remained unidentified. They differed from C. paulus by 1-2 bases and an indel, and from C. paululus by 2 bases and 0-1 indels in ITS. Peculiarly, their RPB2 sequences deviated from each other, but were also intermediate. The spore size resembled $C$. paululus. They grew in the northernmost Finland: one in the alpine zone near S. reticulata and Dryas, and the other by a subarctic lake shore.

SPECIMENS EXAMINED: FINLAND. Inarin Lappi. Utsjoki, Pulmankijärvi, 28.VIII.2005 Kokkonen 504/05*, Tsuomasvarri, 27.VIII.2005 Kokkonen 507/05*.

A collection from the Swiss Alps differed from the $C$. pauperculus type by 5 bases and 3 indels, and from the other species of this complex by at least 4 bases. It and a nearby collection of the same species had a yellow brown veil and squamulose, dark brown pilei. The spores resembled the spores of other species in this complex. The collections resemble rather much C. pertristis J.Favre, which has a more or less smooth pileus (Favre 1955). They may represent a new species, but more data is needed.

SPECIMENS EXAMINED: SWITZERLAND. Graubünden. Scuol, Lai Sesvenna, alt. 2660 m, near Salix herbacea, 25.VIII.2019 Kokkonen 33/19, 37/19*.

\section{CORTINARIUS RUSTICELLUS COMPLEX}

Figure 10

Cortinarius rusticellus J.Favre, Ergebn. Wiss. Unters. Schweiz. Natl. Parks 5 (33): 204 (1955)

Cortinarius lamoureae Bon, Doc. Mycol. 16(63-64): 62 (1986)
Synonym Cortinarius fallax Lamoure, Trav. Sci. Parc Natl. Vanoise 9: 96 (1978), nom. illegit.

Cortinarius rusticellus grows rather commonly in Salix thickets of eastern and northern Finland. The identification was based on comparison with the descriptions of Favre (1955) and Horak (1987) along with collections from the Swiss Alps. Seven high-alpine collections of $C$. rusticellus were genetically identical or had at most a two indel difference by ITS compared with the boreal collections. The collections from both habitats had similar large spores with a suprahilar depression as the lectotype (Horak 1987) and characteristic red brown or dark brown fruitbodies with fibrillose stipes. The colour of the veil varied. It was whitish to yellow brown among the alpine collections, but white or whitish in boreal collections, except distinctly yellow brown in one collection of young fungi. Few boreal collections had scarce brownish fibrillae on the pileus. Favre (1955) described the cortina and ring as pale reddish brown.

The boreal fungi were larger and had smoother pilei than the alpine fungi. Their pileus diameter varied $11-38 \mathrm{~mm}$. The pileus was red brown or dark red brown with a darker centre, and usually umbonate and smooth, but at times slightly fibrillose or flocculose at margin, or rarely entirely delicately fibrillose. The lamellae were red brown or rather dark, and often broad. The stipe size was $28-70 \times$ $1.5-8 \mathrm{~mm}$. It was equal or tapered downwards, had a yellowish brown or pale grey apex darkening to red brown downwards, and a ring or a band along with floccules or merely floccules.

The spore sizes varied much among both the boreal and alpine collections. The ranges of mean values were $8.5-11.1 \times 5.1-6.0 \mu \mathrm{m}$ (11 boreal collections) and 8.3-11.0 × 5.2-6.2 $\mu \mathrm{m}$ (7 alpine collections). The overall variation of boreal spores was $7.7-9.5-13.0 \times 4.7-\underline{5.5}-6.5 \mu \mathrm{m}$. The mean Q value varied 1.63-1.86 (boreal) and 1.61-1.76 (alpine). The spores were usually ellipsoid, but occasionally subamygdaloid or amygdaloid spores were about as frequent as ellipsoid spores, and occasionally also cylindrical spores occurred. The suprahilar depression was usually frequent. The spores were strongly verrucose having larger verrucae at apex, except 

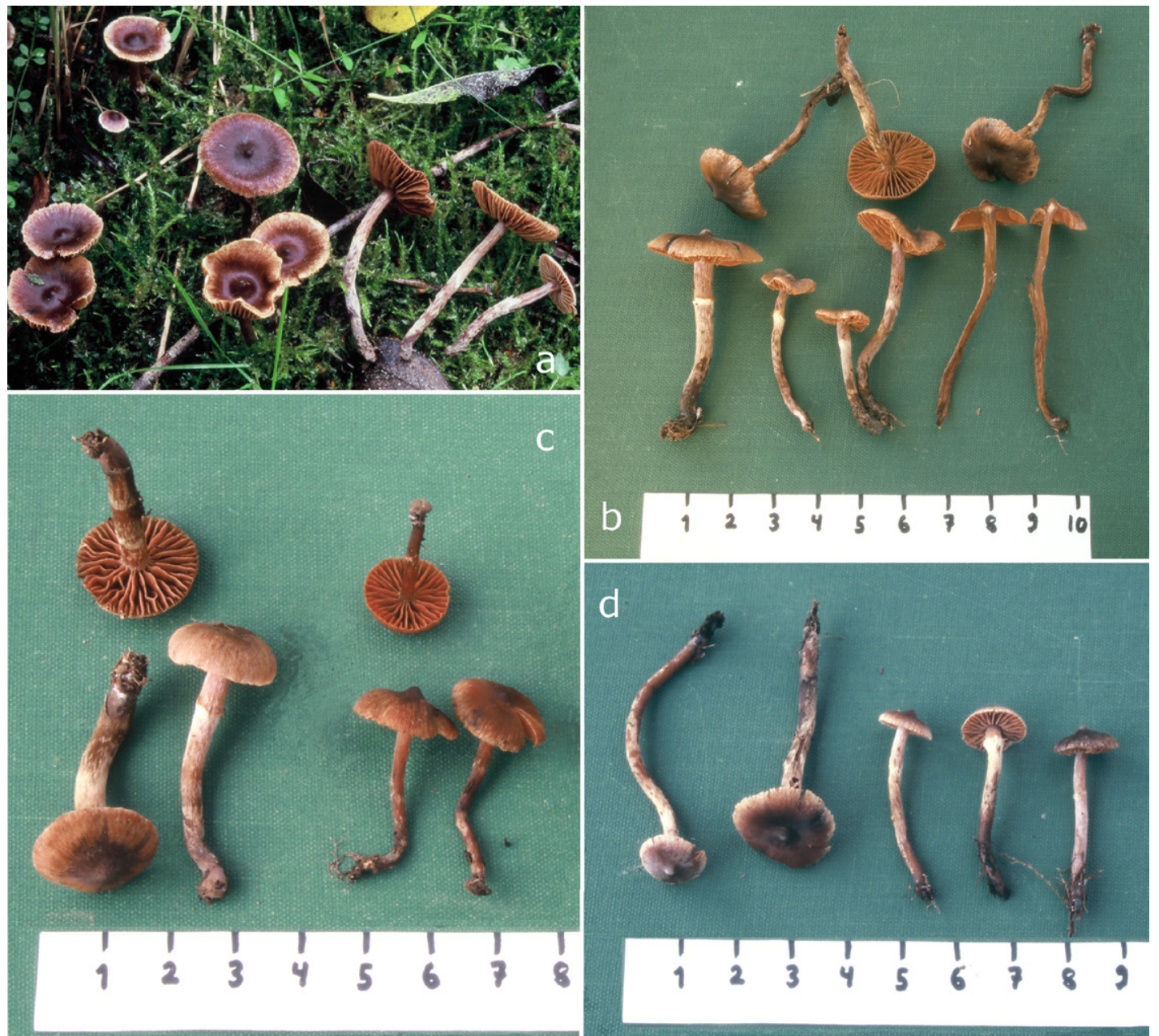

Fig. 10. Cortinarius rusticellus complex, Finland. a C. rusticellus. Nurmes, KK 136/09.

b C. rusticelloides. Valtimo, holotype. c C. rusticelloides. Valtimo, KK 117/02 on the left, KK 115/02 on the right. d C. rusticelloides. Nurmes, KK 118/02.

moderately verrucose in one alpine collection, and moderately to strongly dextrinoid. The lamellar hyphae were strongly encrusted and had nearly always dark flecks.

The boreal collections originated from the transition between the southern and middle boreal zones to the northern boreal zone. Sometimes only S. phylicifolia and S. myrsinifolia were present in the Salix thickets. The species is probably connected only with Salix. The soil varied from muddy to sand. The alpine fungi grew among $S$. herbacea.
The holotype of $C$. fallax Lamoure (IF: nom. illegit., now C. lamoureae Bon) had an identical ITS sequence with the rusticellus sequences and is regarded as conspecific. It was collected from the Italian Alps. Cortinarius lamoureae is not reduced here to a synonym, since the type of $C$. rusticellus was not examined. The morphological description of $C$. fallax (Lamoure 1978) agrees by large with C. rusticellus. The rather dark fruitbodies had abundant brownish veil and large spores. In contrast with C. rusticellus (Favre 1955), the pileus was smooth or only delicately fibril- 


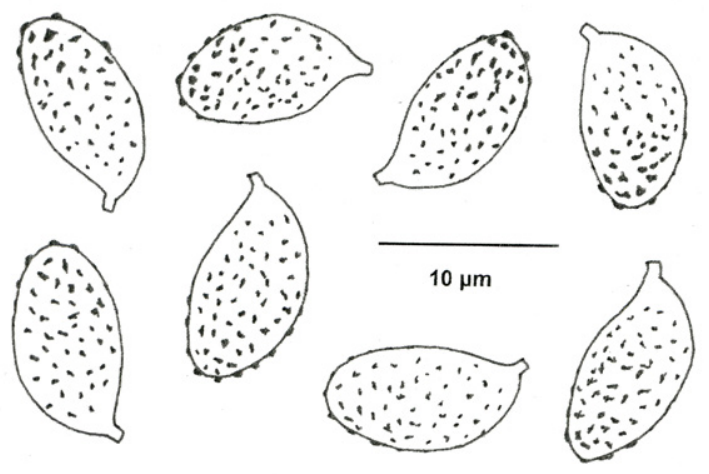

Fig. 11. Cortinarius rusticelloides. Holotype: spores.

lose. The spores lacked the suprahilar depression.

The ITS sequences of three boreal collections deviated by one base from the majority, but they are regarded as conspecific. No morphological differences were observed, and some specimens had ambiguous bases in two of the deviant positions. In addition, the two paratypes of C. pseudofusisporus Bidaud (Bidaud et al. 2010) deviated by one base from most rusticellus specimens. They are regarded as conspecific with some doubt. Their spores were predominantly obtusely amygdaloid or fusoid. The mean sizes of the large spores were $10.6 \times 6.1 \mu \mathrm{m}$ and $11.6 \times 5.8 \mu \mathrm{m}$. The macroscopical description largely agrees with $C$. rusticellus. The fungi were collected under Betula pendu$l a$ and Salix aurita near a pond in France.

HOLOTYPE: Cortinarius fallax Lamoure. Italy, Sondrio, Bormio, under Pass of Stelvio, alt. N 2600 m, Salix herbacea, 20.VIII.1973 D. Lamoure (LY). - Part of type as a loan. Spores 9.1- $\underline{10.0}-10.8 \times 5.4-\underline{6.2}-$ $6.9 \mu \mathrm{m}, \mathrm{Q}=1.47-\underline{1.61}-1.78(\mathrm{n}=20)$; usually ellipsoid, occasionally obtusely amygdaloid, without a suprahilar depression; rather strongly verrucose; weakly dextrinoid. Lamellar hyphae strongly encrusted.

OTHER SPECIMENS EXAMINED: FINLAND. Pohjois-Karjala. Nurmes, Joki-Vastimo, 18.IX.2003 Kokkonen 699/03*, 9.X.2003 Kokkonen 1004/03,
Metsä-Vastimo, 3.IX.2009 Kokkonen 163/09, 16.IX.2009 Kokkonen 285/09*, Pahakala, 16.IX.2002 Kokkonen 140/02, 15.IX.2003 Kokkonen 649/03*, 11.VIII.2009 Kokkonen 56/09*, 29.VIII.2009 Kokkonen 136/09*, 137/09*, 16.IX.2009 Kokkonen 282/09*. Valtimo, Haapakylä, Heinälampi, 20.IX.2003 Kokkonen 765/03*, Mahalanniemi, 5.X.2003 Kokkonen 921/03*, mouth of Matkusjoki, 17.IX.2003 Kokkonen 663/03*, 674/03*, 27.IX.2018 Kokkonen 33/18*. Perä-Pohjanmaa. Kemijärvi, Vuostimo, 31.VIII.2005 Kokkonen 497/05\%. Koillismaa. Kuusamo, near Kuolio, 13.VIII.2006 Kokkonen 150/06*, Vuotunki, 31.VIII.2007 Kokkonen 542/07 and J. Vauras. Kittilän Lappi.Kittilä, Köngäs, 15.VIII.2006 Kokkonen 165/06*, Sirkka, 16.VIII.2006 Kokkonen 176/06*. Enontekiön Lappi. Enontekiö, Peltovuoma, 22.VIII.2006 Kokkonen 311/06*. FRANCE. Dordogne. Salagnac, Forêt de Born, alt. 200 m, 27.X.1997 leg. E. Bidaud, AB 97-10417*, АВ 97-10-418* (Herb. A. Bidaud, as C. pseudofusisporus). SWEDEN. Lycksele Lappmark. Sorsele, Rankbäcken W of Nissebo, 28.VIII.2016 Kokkonen 367/16\%. SWITZERLAND. Graubünden. Scuol, Piz Clünas, alt. 2640 m, 16.VIII.2017 Kokkonen 287/17*, Val Sesvenna, alt. ca. 2525 m, 14.VIII.2017 Kokkonen

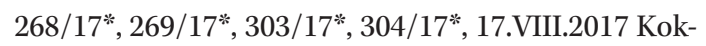
konen $282 / 17^{*}, 312 / 17^{*}$.

\section{Cortinarius rusticelloides Kokkonen, sp. nov.}

\section{MycoBank MB833744}

Figures $10 \mathrm{~b}-\mathrm{d}$ and 11

HOLOTYPE: Finland, Pohjois-Karjala, Valtimo, Haapakylä, Heinälampi, shore of a pond connected to river, Salix thicket with S. phylicifolia and $S$. myrsinifolia, scattered Betula and Alnus incana, 3.IX.2002 K. Kokkonen 136/02 (TUR; isotypes G, IB), ITS MN841216.

PILEUS diameter 9-36 mm; applanate, campanulate or convex with papilla or low umbo, at times margin undulate; usually dark brown, or red brown, centre often blackish; smooth or delicately fibrillose, margin at times with white veil remnants; hygrophanous, translucently striate. LAMELLAE emarginate or adnate, moderately crowded or rather distant; dark brown or red brown, edge paler. STIPE 10-50 mm long, $1.5-5.5 \mathrm{~mm}$ wide; equal or tapering downwards; dark brown or red brown with 
whitish fibrillose cover; usually a white band or ring, often white floccose below the ring, at times only few flocci or a white sheath below the ring. CONTEXT yellow brown or dark brown. CORTINA white. SMELL not distinctive.

SPORES $8.9-\underline{10.5}-12.9 \times 5.0-\underline{5.7}-6.5 \mu \mathrm{m}$, range of mean values $10.1-11.3 \times 5.5-5.8 \mu \mathrm{m}$, $\mathrm{Q}=1.61-1.85-2.17$, range of mean $\mathrm{Q}$ values $1.75-$ 1.98 (160 spores from 8 collections); predominantly amygdaloid or fusoid, some narrow ellipsoid, rarely amygdaloid and ellipsoid spores about as frequent, occasionally some spores cylindrical, a suprahilar depression usually frequent; strongly verrucose with larger verrucae at apex; rather strongly or strongly dextrinoid, rarely rather weakly dextrinoid. BASIDIA 25-38 x 8-12 $\mu \mathrm{m}(\mathrm{n}=26)$, 4-spored. CHEILOCYSTIDIA absent. LAMELLAR HYPHAE strongly encrusted and with dark flecks, rarely flecks absent. PILEIPELLIS hyphae $1.5-31 \mu \mathrm{m}$ wide, brownish or hyaline, mostly strongly coarsely encrusted, with dark red brown or yellow brown flecks.

HABITAT AND DISTRIBUTION: known from five localities in eastern Finland. The habitats were moist Salix thickets by lakes, rivers and a spring in the transition zone between the southern and middle boreal zones. The species is connected with $\mathrm{Sa}$ lix, since only S. phylicifolia and S. myrsinifolia were present in one locality.

SPECIMENS EXAMINED: FINLAND. Pohjois-Karjala. Nurmes, Kynsisaari, 30.VII.2013 Kokkonen 12/13*, Metelinmäki, 31.VIII.2002 Kokkonen 57/02*, 2.IX.2002 Kokkonen 118/02*. Valtimo, Haapakylä, Heinälampi, 3.IX.2002 Kokkonen 136/02 (holotype)*, Mahalanniemi, 18.IX.2002 Kokkonen 112/02*, 5.X.2003 Kokkonen 922/03*, mouth of Matkusjoki, 2.IX.2002 Kokkonen 116/02*, 21.IX.2002 Kokkonen 115/02*, 117/02*, 135/02*, 18.IX.2003 Kokkonen 724/03*.

COMMENTS: A species differing genetically and morphologically slightly from C. rusticellus is described here as a new species, $C$. rusticelloides. It shared some sites with $C$. rusticellus in eastern Finland. They differed genetically only by 2 bases in ITS, but there appeared no intermediates, and the RPB2 sequences deviated by $12-13$ bases and two long indels from each other. As comparison, the variation of RPB2 sequences within C. rusticellus was up to three bases among four specimens, and there oc- curred often ambiguous bases in these positions. Only one complete RPB2 sequence was obtained from C. rusticelloides, but an incomplete other sequence was nearly identical. The morphologies of the two species overlapped, but especially within sites, the spores had different shapes. The spores of C. rusticelloides were more often amygdaloid or fusoid. They were larger or about the same size compared with rusticellus spores within sites. Their size did not vary as much as observed with $C$. rusticellus. Macromorphologically, both had a band or floccules at stipe, but the colour of C. rusticelloides seemed often duller. No described species was found to match C. rusticelloides.

\section{Cortinarius friesianus Carteret \& Reumaux, Atlas des Cortinaires 11: 572 (2001) \\ Synonym Cortinarius flexibilifolius Carteret, Atlas des Cortinaires 14: 906 (2004)}

Cortinarius friesianus and C. flexibilifolius were genetically close to $C$. rusticellus and $C$. rusticelloides. The ITS sequences of their types deviated from $C$. rusticelloides by 4 bases and 2 indels and from $C$. rusticellus by 6 bases and 2 indels. Cortinarius flexibilifolius is reduced to a synonym of $C$. friesianus, since they had identical sequences and similar morphology. The types were also collected by the same lake (Bidaud et al. 2001, 2004). The habitus of $C$. flexibilifolius resembles the habitus of $C$. rusticellus and C. rusticelloides, since its stipe had a similar band, whereas the stipe of $C$. friesianus was entirely pale. Both C. flexibilifolius and C. friesianus had ellipsoid spores, deviating thus from the spores of $C$. rusticelloides. The spores were strongly verrucose, but $C$. friesianus had on average narrower spores than $C$. flexibilifolius.

HOLOTYPE: Cortinarius friesianus Carteret \& Reumaux. France, île-de-France, Maurepas forest, shore of Lake Courance, under Salix sp. and Betula pendula, 24.XI.1997 X. Carteret, no 97112425

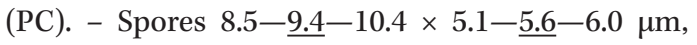
$\mathrm{Q}=1.48-1.67-1.86,(\mathrm{n}=20)$; ellipsoid, occasionally subamygdaloid, suprahilar depression occasional; strongly verrucose; strongly dextrinoid; lamellar hyphae strongly encrusted and with dark flecks.

HOLOTYPE: Cortinarius flexibilifolius Carteret. 
France, île-de-France, Maurepas forest, shore of Lake Courance, under hygrophilous trees (incl. Salix, Alnus, Populus and Betula), 13.XI.2003 X. Carteret, no

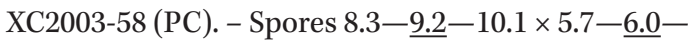
$6.3 \mu \mathrm{m}, \mathrm{Q}=1.41-1.55-1.71,(\mathrm{n}=20)$; ellipsoid, rarely subamygdaloid, suprahilar depression occasional; strongly verrucose; strongly dextrinoid. Lamellar hyphae strongly encrusted and with dark flecks.

\section{CORTINARIUS SANIOSUS COMPLEX}

Figure 12

Cortinarius saniosus (Fr.:Fr.) Fr., Epicr. Syst. Mycol.: 313 (1838)

Synonyms C. bavaricus M.M.Moser, Mycol. Helv. 1(1): 10 (1983)

C. aureomarginatus P.D.Orton, fide Lindström et al. 2008

C. chrysomallus Lamoure, fide Lindström et al. 2008

Cortinarius saniosus is probably the most common Cortinarius in boreal Salix thickets of Finland. Lindström et al. (2008) published an extensive morphological and genetic study of $C$. saniosus complex. Both C. aureomarginatus P.D.Orton from lowland England and C. chrysomallus Lamoure from alpine habitats were concluded to belong to the variation of C. saniosus. Cortinarius saniosus was found to grow with many hosts and in many habitats, and the small genetic variation could not be connected to morphological or ecological differences. Similarly, my collections from Salix habitats revealed a variation up to 2 bases and 2 indels in ITS, but they formed a coherent clade including the types of $C$. aureomarginatus, C. chrysomallus (from GenBank) and $C$. bavaricus. The genetic variation could not be connected to morphological variation with this limited material. Excluding the common yellow veil, the colour, size and spore morphology varied rather much. The pileus varied from dark brown to orange brown, the spore size from the usual $8-10 \times 5.5-$ $6.5 \mu \mathrm{m}$ to ca. $7.5-8.5 \times 5-6 \mu \mathrm{m}$, and the spore shape from rather broad to narrowish ellipsoid among collections with identical sequences. Some collections had both ellipsoid and ovoid spores. All had rather strongly to strongly verrucose and moderately to strongly dextrinoid spores. Unlike Lindstöm et al. (2008), violaceous colour was never observed at lamellae or stipe. The ITS sequence of the C. bavaricus type was identical or differed only by one or few indels from most saniosus specimens. The spores and other morphology of C. bavaricus (Moser 1983) also are similar with $C$. saniosus. Consequently, $C$. bavaricus is reduced to a synonym. The type was collected under Alnus incana in Germany.

HOLOTYPE: Cortinarius bavaricus M.M.Moser. Germany, Bayern, Bayrischen Wald, shore by Gumpenfried, under Alnus incana, 3.IX.1967 M. Moser (IB-Nr. 1967/0102). - Part of type as a loan. Spores 7.0-7.9-9.0 x 4.9-5.4-5.7 $\mu \mathrm{m}, \mathrm{Q}=1.31-$ 1.47-1.64 ( $\mathrm{n}=20)$; ellipsoid or ovoid; strongly verrucose, verrucae larger at apex; moderately dextrinoid.

OTHER SPECIMENS EXAMINED: FINLAND. Pohjois-Karjala. Nurmes, Metsä-Vastimo, 20.VII.2002 Kokkonen 129/02*, 24.IX.2002 Kokkonen 21/02*, 30.VIII.2003 Kokkonen 306/03*, Pahakala, 26.VIII.2002 58/02*, 18.VIII.2003 Kokkonen 154/03*. Valtimo, Haapakylä, Heinälampi, 24.IX.2002 Kokkonen $39 / 02^{*}$, $137 / 02^{*}$, mouth of the river Matkusjoki, 29.VIII.2003 Kokkonen 1060/03\%. Koillismaa. Kuusamo, Oulanka National Park, SW of Nurmisaarenrinne, 18.IX.2019 Kokkonen 100/19*, Vuotunki, 31.VIII.2007 Kokkonen 540/07* and J. Vauras. Kittilän Lappi. Kittilä, Sirkka, 16.VIII.2006 Kokkonen 174/06*. Sompion Lappi. Savukoski, Värriöjoki, 18.VIII.2019 Kokkonen 6/19*. Enontekiön Lappi. Enontekiö, Kaaresuvanto, 20.VIII.2006 Kokkonen 267/06*, Peltovuoma, 22.VIII.2006 Kokkonen 299/06*. Inarin Lappi. Utsjoki, Kevo, 29.VIII.2005 Kokkonen 513/05*, Tsuomasvarri, near S. reticulata, 26.VIII.2005 Kokkonen 508/05*. ICELAND. Suđur-ĺsland. Rangárping eystra, N of Valahnúkur, on moor near S. arctica and Betula, 16.IX.2017 Kokkonen 359/17*. NORWAY. Nord-Trøndelag. Fjeld between Sanddøldalen and Blåfjella-Skækerfjella Nasjonalpark, near S. herbacea, 26.VIII.2016 Kokkonen $347 / 16^{*}$. SWEDEN. Lule Lappmark. Gällivare, Nieras, near S. herbacea, 30.VIII.2016 Kokkonen $1384 / 16^{*}$ 


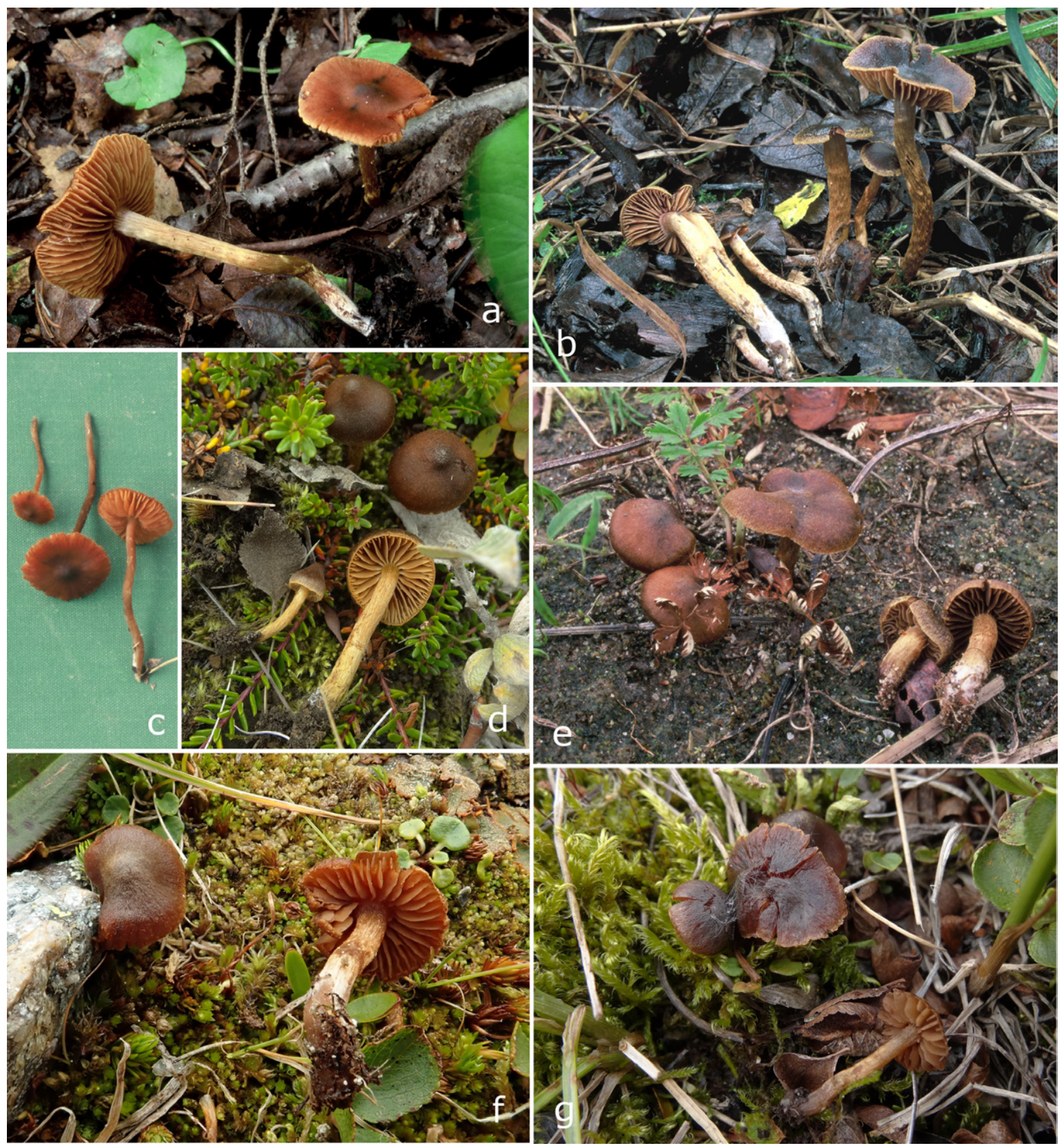

Fig. 12. Cortinarius saniosus complex. a C. saniosus. Finland, Nurmes, KK 154/O3.

b C. saniosus. Finland, Valtimo, KK 1060/03. c C. saniosus. Finland, Valtimo, KK 39/02.

d C. saniosus. Iceland, KK 359/17. e C. subsaniosus. Finland, Kalajoki, KK 246/04.

f C. aff. saniosus. Switzerland, KK 35/19. g C. aff. saniosus. Switzerland, KK 307/17. 

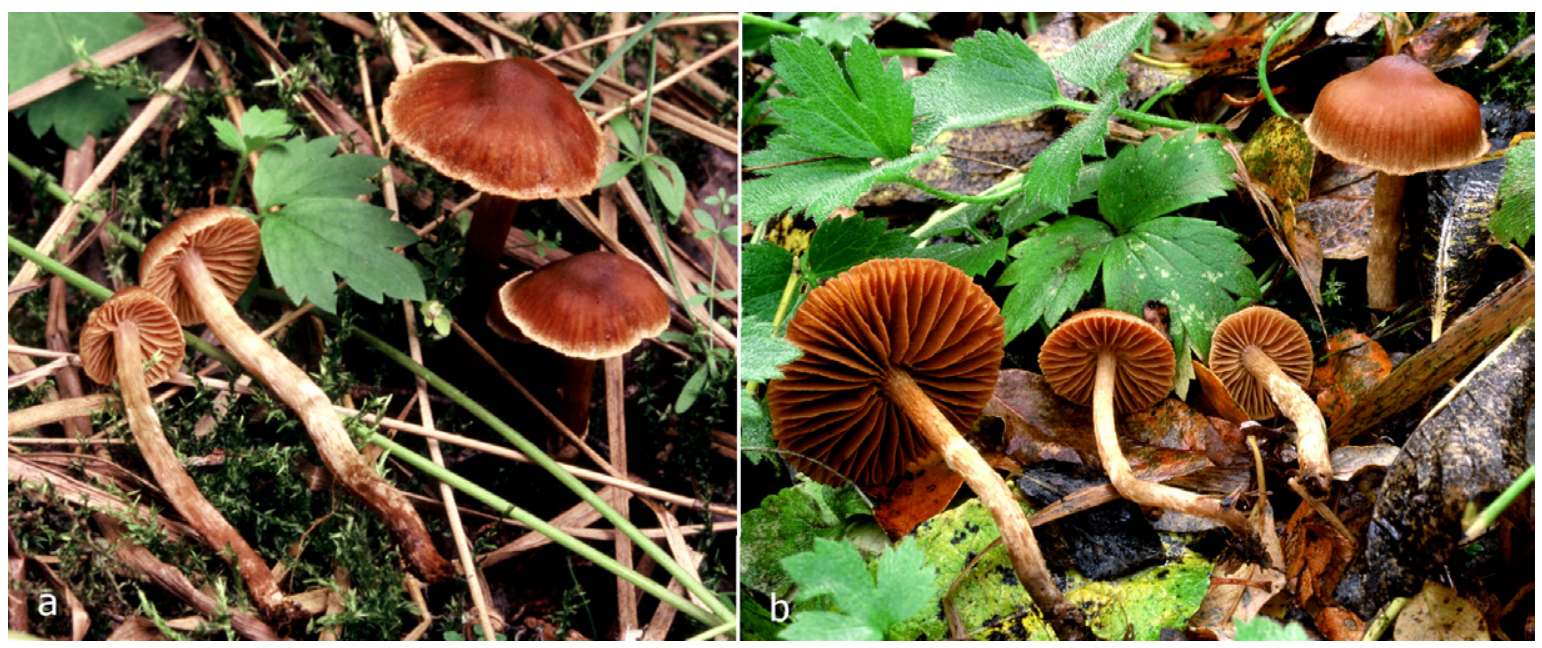

Fig. 13. Cortinarius vienoi, Finland, Valtimo. a Holotype. b KK 679/03.

Cortinarius subsaniosus Liimat. \& Niskanen, Fungal Diversity 100: 252 (2020)

One collection from a sandy seashore near Salix phylicifolia and Alnus incana in the middle boreal zone of Finland deviated from $C$. saniosus mostly by $9-10$ bases and 5 indels. Its ITS sequence was identical with a clade 2 collection of Lindström et al. (2008) from a Swedish lake shore with e.g. $S$. phylicifolia and near their clade 2 sequences from Nordic seashores with Salix repens. This species was recently described as C. subsaniosus Liimat. \& Niskanen (Hyde et al. 2020). According to the protologue, it grows on sand with Salix and possibly other hosts. The type is from England. The species seems to be rare inland, since it was not among my many sequenced saniosus specimens from inland muddy or sandy shores. The morphology of my subsaniosus collection differed from the protologue description by a stouter habitus (Fig. 12e), a red brown pileus with an indistinct or obtuse umbo, and smaller spores. The spore size was ca. $8-10 \times 5.5-6 \mu \mathrm{m}$ with a mean $9.1 \times 5.7 \mu \mathrm{m}$. The spores were ellipsoid or rarely sybamygdaloid. Most lamellar hyphae were slightly to moderately encrusted.

SPECIMEN EXAMINED: FINLAND. Keski-Pohjanmaa. Kalajoki, Hiekkasärkät, 10.IX.2004 Kokkonen $246 / 04 \%$.

\section{Cortinarius sp.}

The clade 2 of Lindström et al. (2008) included also a separate sequence from the Austrian Alps. Six collections of this study from the Swiss Alps had identical sequences with their clade 2 Austrian specimen. They deviated by 6 bases and 3 indels from $C$. subsaniosus and are regarded here as a separate species. They resembled morphologically $C$. saniosus and $C$. subsaniosus, but some had a scarcer and paler veil. One had a dark red stipe base. More material may establish morphological, ecological, and/or geographical differences among the three species. Lindström et al. (2008) presumed clade 2 to be a separate taxon from $C$. saniosus but refrained from conclusions owing to lack of morphological differences.

\section{SPECIMENS EXAMINED: SWITZERLAND.} Graubünden. Scuol, Lai Sesvenna, alt. 2665 m, near S. herbacea, 25.VIII.2019 Kokkonen 35/19*, Val Sesvenna, near $S$. herbacea, alt. $2525 \mathrm{~m}, 14$. VIII.2017 Kokkonen 306/17*, 307/17*, 360/17*, 17.VIII.2017 Kokkonen $283 / 17^{*}, 316 / 17^{*}$. 

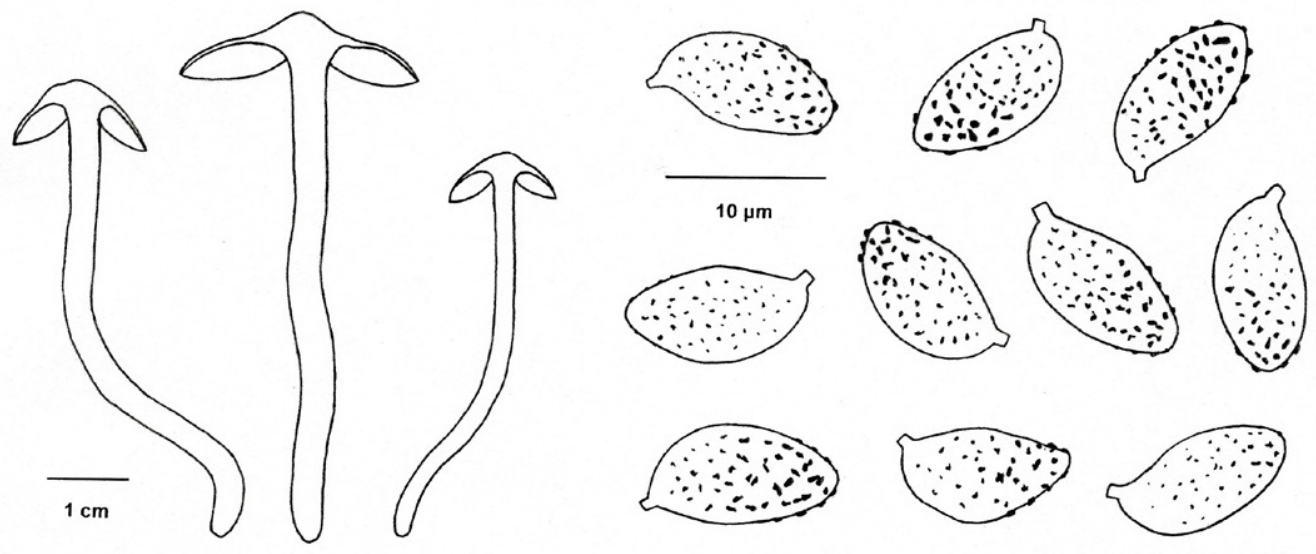

Fig. 14. Cortinarius vienoi. Holotype: cross-sections of fruitbodies and spores.

\section{CORTINARIUS VIENOI}

Kokkonen, sp. nov.

MycoBank MB833746

Figures 13 and 14

ETYMOLOGY: named for the memory of my father, Vieno Kokkonen. He cared for the type locality area.

HOLOTYPE: Finland, Pohjois-Karjala, Valtimo, Haapakylä, Autioniemi, lakeside Salix thicket with S. phylicifolia and S. myrsinifolia, further away Alnus incana and Betula, 6.VIII.2008 K. Kokkonen 52/08 (TUR; isotype PC), ITS MN841238.

PILEUS 9-35 $\mathrm{mm}$ in diameter; conical when young, later broader conical or campanulate with an obtuse or rather acute umbo; red brown or ochraceous brown (ca. $\mathrm{S}_{40} \mathrm{Y}_{70} \mathrm{M}_{50}$ ), centre darker, margin pale; delicately silky fibrillose or nearly smooth, margin pale fibrillose and at times with white veil remnants; dry, hygrophanous, translucently striate. LAMELLAE moderately broad, narrowly adnate, moderately crowded or rather distant; red brown or ochraceous brown $\left(\mathrm{S}_{40} \mathrm{Y}_{80} \mathrm{M}_{50}\right)$, when young paler $\left(\mathrm{S}_{30} \mathrm{Y}_{60} \mathrm{M}_{40}\right)$; edge fimbriate and paler. STIPE 40-65 $\mathrm{mm}$ long, 2.5-4.5 $\mathrm{mm}$ wide; equal, base roundish or somewhat tapering; when young greyish, then pale yellow brown; veil abundant, white or whitish, forming usually a distinct ring or band in the middle and floccules below, more rarely the lower part only with few flocci or with a whitish cover; dry, fibrillose, at times base white pubescent; stuffed or fistulose when old. CONTEXT red brown or yellow brown. CORTINA pale. SMELL and taste not distinctive.

SPORES $9.5-\underline{10.8}-13.8 \times 4.7-\underline{5.5}-6.3 \mu \mathrm{m}$, range of mean values $10.4-11.3 \times 5.4-5.6 \mu \mathrm{m}$, $\mathrm{Q}=1.71-1.97-2.53$, range of mean $\mathrm{Q}$ values 1.90 2.08 (80 spores from 4 collections); usually fusoid or amygdaloid, occasionally narrow ellipsoid, often with a suprahilar depression, rarely constricted near the apex; moderately to strongly verrucose, verrucae usually larger at apex; rather strongly to strongly dextrinoid. BASIDIA $27-40 \times 7-10 \mu \mathrm{m}$

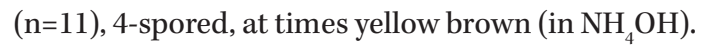
LAMELLAR HYPHAE variably encrusted: usually weakly, but few hyphae may be strongly encrusted. PILEIPELlis hyphae $1.5-30 \mu \mathrm{m}$ wide, pale red brown or hyaline, mostly rather strongly or strongly coarsely encrusted.

HABITAT: inland shores or swamps with Salix thickets. The soil is mesotrophic or eutrophic. It is connected at least with $S$. phylicifolia and/or $S$. myrsinifolia, since no other trees grew at one site.

DISTRIBUTION: known from four sites in eastern Finland, from the middle and northern boreal zones. Two of the sites were by the same lake.

SPECIMENS EXAMINED: FINLAND. PohjoisKarjala. Valtimo, Haapakylä, Autioniemi, 6.VIII.2008 Kokkonen 52/08* (holotype), mouth of the river Mat- 


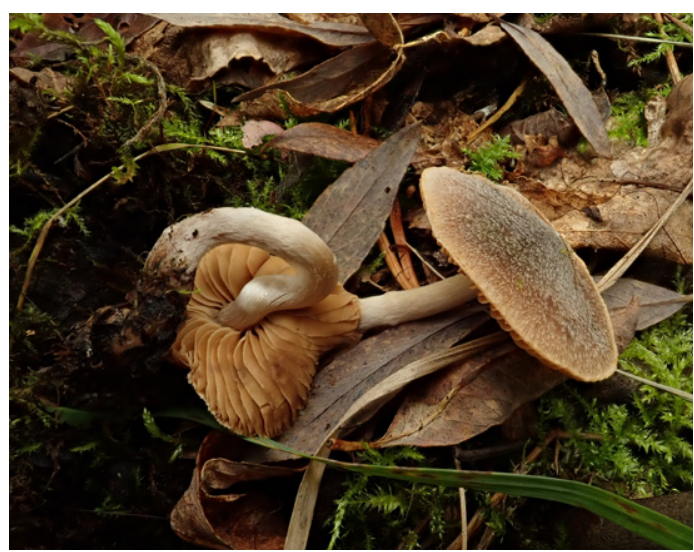

Fig. 15. Cortinarius boreotrichus. Finland, Kuhmo, KK 644/18, Metsähallitus.

kusjoki, thicket with Salix phylicifolia and S. myrsinifolia, 18.IX.2003 Kokkonen 679/03*. Koillismaa. Kuusamo, Oulanka National Park, Jäkälämutka, under S. phylicifolia, 17.IX.2019 Kokkonen 91/19*, Nurmisaarenniemi, swamp, thicket with $S$. phylicifolia and S. lapponum, near also Betula and Picea abies, 18.VIII.2008 Kokkonen 74/08* and J. Vauras.

COMMENTS: Cortinarius vienoi is characterized by red brown or yellowish brown fruitbodies with a delicately fibrillose pileus, abundantly white floccose stipe, large fusoid spores, and growth with Salix. It is probably a rare species, since only four localities were found, and no sequences matched in public databases. Holotype had an ambiguous base in a position, where other sequences had different bases.

Cortinarius perzonatus Reumaux is both genetically and morphologically a close species. The ITS sequence of the perzonatus holotype deviated from the vienoi sequences by 5-7 bases and 5 indels excluding ambiguous bases. Both have a similar habitus, but C. perzonatus has a scarcer veil (Bidaud et al. 2004), and its type spores were shorter with a lower $Q$ value as well as of different shape: predominantly ellipsoid and only rarely distinctly fusoid. Cortinarius perzonatus was described growing under hygrophilous trees in France, but there exists a nearly identical sequence with the type in GenBank from a Quercus mycorrhiza in Romania (KM576365,
Suz et al. 2014). Thus, the two species seem to have different hosts.

Cortinarius pseudofusisporus Bidaud resembles morphologically C. vienoi, but its holotype differed genetically distinctly, belonging to the $C$. decipiens complex. The rather similar C. neglectus Carteret was distant according to the type study. Cortinarius cucumisporus M.M.Moser has large fusoid spores and it grows with Salix, as explained above, but also it was distant. Other small Telamonia species with fusoid spores differ for example by growing in coniferous forests or having a dissimilar morphology.

\section{OTHER SPECIES FROM SALIX THICKETS}

\section{Cortinarius boreotrichus Kytöv., Niskanen \& Liimat., Index Fungorum 339:1 (2017)}

Figure 15

Cortinarius boreotrichus grew under Salix phylicifolia and near Betula by a brook in the transition zone between the middle and northern boreal zones. Formerly it has been known only from one mixed riverside forest in the northern boreal zone (Liimatainen 2017). The morphology resembled the original description, except that the pileus was dark brown and entirely squarrulose. The spores were ca. 8-9.5 × 4.5-5 $\mu \mathrm{m}$, narrowly ellipsoid - cylindrical - subamygdaloid, rather weakly verrucose, and moderately dextrinoid. The ITS sequence was identical with the type (GenBank MF379638). The species may be connected with Betula, since it was not found from other Salix sites. The species is closely related to the Salix associate C. gossypinus. Their ITS sequences deviated by 7-10 bases and 1-2 indels from each other. Both are characterized by hairy or squamulose pilei.

SPECIMEN EXAMINED: FINLAND. Kainuu. Kuhmo, NW of Koirakangas, by Koirapuro, 8.IX.2018 Kokkonen 644/18*. 
Cortinarius aff. erubescens M.M.Moser, Nova Hedwigia 14(2-4): 515 (1968)

Two boreal collections growing among Salix phylicifolia and S. lapponum bushes were morphologically and genetically close to $C$. erubescens, when compared with two Nordic erubescens collections (BOLD NOBAS2063-16, JV25222 in TUR-A). They may represent a new species, but more data would be needed. Cortinarius pertristis J.Favre has a rather similar morphology (Favre 1955). A genetically identical collection with aff. erubescens was found near Salix herbacea in the Swiss Alps. The difference from C. erubescens was only 2 bases and 3 indels by ITS sequences. The collections were also close to $C$. rusticellus complex, but they had a dissimilar morphology. The closest species of this study, C. rusticelloides, differed by 5 bases and 7 indels. The fungi had a dark pileus, pale stipe, and small spores (ca. $7-8.5 \times$ $4.5-5 \mu \mathrm{m}$ ) similarly to $C$. erubescens, but the spores were moderately verrucose in contrast with the nearly smooth spores of C. erubescens (Moser 1968, Niskanen et al. 2012b). One boreal fruitbody had a red stipe base. The boreal fungi grew by a sandy riverside in the northern boreal zone. The similar C. roseobasilis Ammirati, Beug, Niskanen, Liimat. \& O.Ceska and C. rufescentipes Bidaud are close species. The type of $C$. roseobasilis differed by 4 bases and 5 indels (GenBank NR153059, Li et al. 2016) and the type of $C$. rufescentipes by 9 bases and 4 indels from the aff. erubescens collections.

SPECIMENS EXAMINED: C. aff. erubescens: FINLAND. Koillismaa. Kuusamo, Oulanka National Park, Jäkälämutka, 1.IX.2007 Kokkonen 578/07*, 580/07. SWITZERLAND. Graubünden. Scuol, Val Sesvenna, alt. 2525 m, 17.VIII.2017 Kokkonen 278/17*. C. erubescens: FINLAND. Salla, Morottaja, Heinäpuronkangas, dry heath forest with Pinus sylvestris on fine sandy soil, 2.IX.2007 J. Vauras 25222, det. T. Niskanen (TUR-A)*.

\section{Cortinarius fulvopaludosus Kytöv., Niskanen \& Liimat., Index Fungorum 344: 1 (2017)}

Figure 16

A collection from a boreal mixed shore forest with Salix bushes was identified as C. fulvopaludosus. Its morphology differed from the protologue de-

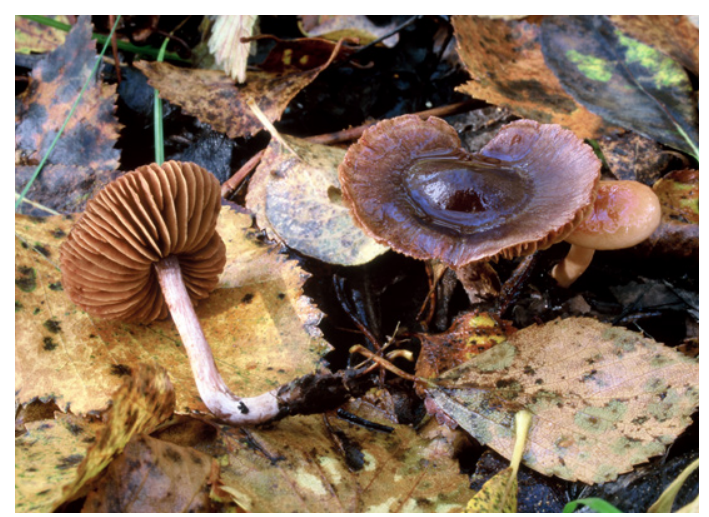

Fig. 16. Cortinarius fulvopaludosus with Lactarius tabidus. Finland, Nurmes, KK 619/03.

scription (Liimatainen 2017) and its ITS sequence one base from the fulvopaludosus type (GenBank NR154868), but one of the two chromatograms had a mixed peak in the deviant position. In contrast to the protologue, the pileus was dark red brown with a blackish centre, the umbo was obtuse, and the stipe was stouter with height $40-45 \mathrm{~mm}$ and width $3.5-$ $6 \mathrm{~mm}$. The smell was strongly raphanoid. A fulvopaludosus specimen from a mixed forest in Italy also had a dark brown pileus. It was genetically identical with the type. The spores of both collections were ellipsoid to obtusely amygdaloid, moderately to rather strongly verrucose, and rather strongly to strongly dextrinoid. The mean spore size of the boreal collection was similar with the original description, but the spores of the Italian collection were smaller with mean $8.0 \times 4.8 \mu \mathrm{m}$. The species is apparently not connected with Salix. In addition to moist mixed forests, it has been found mycorrhizal with Populus and Fagus (Liimatainen 2017).

SPECIMENS EXAMINED: FINLAND. PohjoisKarjala. Nurmes, Pahakala, mixed shore forest by lake with Salix phylicifolia, S. myrsinifolia, Alnus incana, Betula, and Picea abies, 15.IX.2003 Kokkonen 619/03*. ITALY. Trentino. Pergine, Val dei Mochen, forest with Larix decidua, Picea abies, and scattered Betula, Alnus viridis and Fagus sylvatica, under Alnus, margin of moist and more dry soil, 5.X.2002 J. Vauras 19599 (TUR-A, as C. decipiens)*. 


\section{Cortinarius spp.}

A Telamonia species collected among Salix in three localities from the northern boreal to the low-alpine zone could not be identified. It had a dark brown pileus and a pale fibrillous stipe. The fungi from two collections had a prominent umbo and a thin stipe. The spores were ca. $8.5-11 \times 5.5-6$ or $6-7 \mu \mathrm{m}$, ellipsoid to subamygdaloid, strongly or rather weakly verrucose, and rather weakly dextrinoid. The ITS sequences deviated 2 indels at most from each other. Several specimens from arctic habitats had identical sequences in GenBank, and it occurred also in the Swiss Alps among Salix retusa and Dryas. The GenBank specimens were anonymous (Bjorbaekmo et al. 2010, Fujiyoshi et al. 2011, Timling et al. 2012) or identified once as C. tenebricus (Geml et al. 2012). They were connected with Dryas or arctic Salix species. One identical sequence was from Kobresia myosuroides in Austria (Mühlmann \& Peintner 2008). The species is possibly restricted to northern boreal, arctic, and alpine zones.

SPECIMENS EXAMINED: FINLAND. Enontekiön Lappi. Enontekiö, Palojoensuu, riverside Salix thicket with S. phylicifolia and S. lapponum, Betula further away, 19.VIII.2006 Kokkonen 251/06** Inarin Lappi. Utsjoki, Pulmankijärvi, lakeside Salix thicket with e.g. S. phylicifolia and S. lapponum, Betula and Alnus incana further away, 28.VIII.2005 Kokkonen $469 / 05^{*}$, Tsuomasvarri, low alpine zone, near S. myrsinites, S. glauca and Betula nana, 26.VIII.2005 Kokkonen 516/05*. SWITZERLAND. Graubünden. Scuol, Val S-charl, Valbella, alt. 2180 m, 26.VIII.2019 Kokkonen 46/19\%.

A small group of fungi collected from Salix thickets in the middle boreal, northern boreal and subarctic zones was genetically between the comatus and cucumisporus complexes and near some C. flexipes collections (Fig. 19). The habitus resembled for example C. vulpicolor, but the morphology also varied much, which may be due to the habitat. The stipe was often long and slender in boreal Salix thickets, but short on a subarctic sandy ground. The red brown or dark fruitbodies had usually flocculose pilei and fibrillose stipes, but the pileus could also be smooth. The spores were large, mostly $9-11 \times$ $5.5-6 \mu \mathrm{m}$, and ellipsoid or amygdaloid. A specimen deviating by one base from the others had weakly verrucose spores compared with the strongly verrucose spores of others. The group deviated from the Swiss $C$. comatus specimen by 4-5 bases and 4-7 indels, from $C$. vulpicolor and $C$. diasemospermus types by 6-7 bases and 2-5 indels, from $C$. flexipes collections by 3-6 bases and 3-5 indels, and from the North American C. fragrantissimus Ammirati, Beug, Liimat., Niskanen \& O.Ceska type by 3-4 bases and 3-6 indels (GenBank NR153058, Li et al. 2016). It lacked the violaceous lamellae and sweetish smell of $C$. fragrantissimus, indicating a separate species. The identification would require extensive research due to the poorly researched $C$. flexipes complex, and several described species, for example in the Atlas des Cortinaires series, could fit to its variation.

SPECIMENS EXAMINED: FINLAND. PohjoisKarjala. Valtimo, Haapakylä, Heinälampi, 20.IX.2003 Kokkonen 736/03*, mouth of Matkusjoki, 18.IX.2003 Kokkonen 723/03\%. Perä-Pohjanmaa. Kemijärvi, Vuostimo, 31.VIII.2005 Kokkonen 494/05*. Enontekiön Lappi. Enontekiö, Kaaresuvanto, 20.VIII.2006 Kokkonen 271/06*. Inarin Lappi. Utsjoki, Pulmankijärvi, 28.VIII.2005 Kokkonen 512/05*.

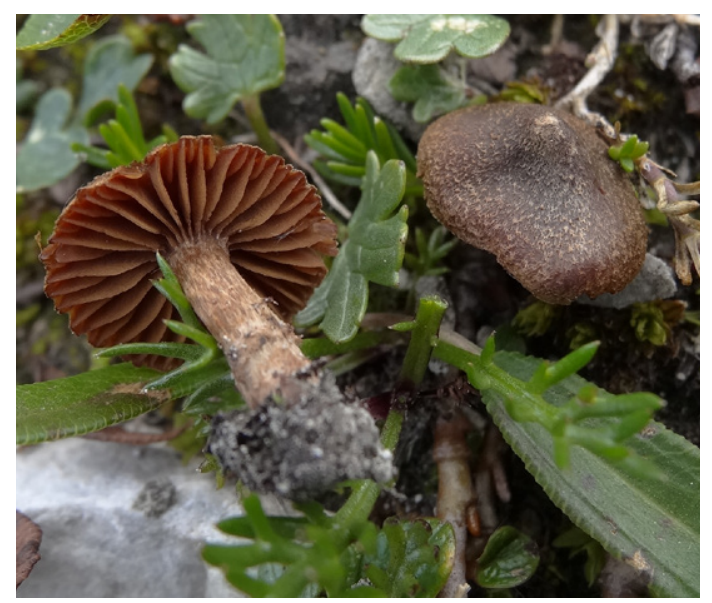

Fig. 17. Cortinarius gausapatus. Switzerland, KK 262/17. 


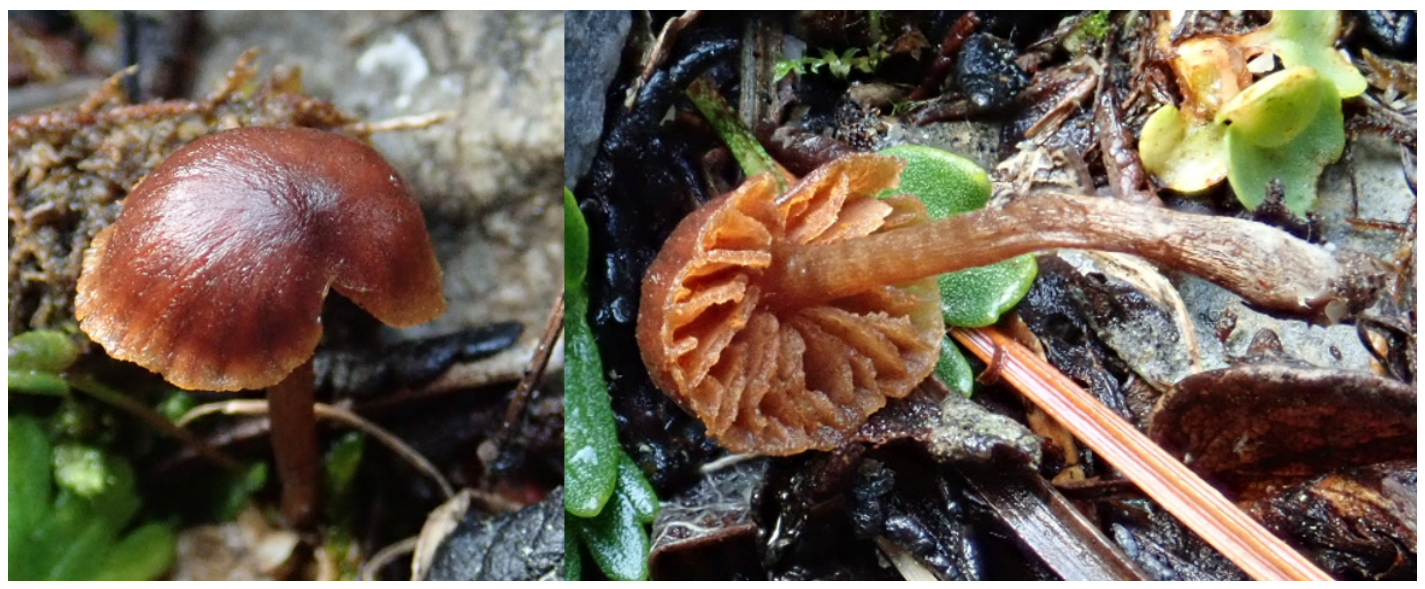

Fig. 18. Cortinarius galerinoides. Switzerland, KK 44/19.

\section{ADDITIONAL EXAMINED TYPES AND SPECIMENS}

\section{Cortinarius fistularis Britz., Hymenomyc.} Südbayern 4: 132 (1891)

SPECIMEN EXAMINED: Cortinarius fistularis Britz. France, Ardennes, Sommauthe forest, under hygrophilous deciduous trees, 23.IX.1986 leg. P. Reumaux (Herb. P. Moënne-Loccoz no. 4134). - Part of specimen as a loan. Spores $7.1-\underline{8.1}-9.6 \times 5.0-\underline{5.7}-6.0$ $\mu \mathrm{m}, \mathrm{Q}=1.29-1.44-1.63(\mathrm{n}=20)$; ordinary or broadly ellipsoid; moderately verrucose; rather weakly dextrinoid. Lamellar hyphae rather strongly encrusted.

Cortinarius gausapatus J.Favre, Ergebn. Wiss. Unters. Schweiz. Natl. Parks 5 (33): 202 (1955)

Figure 17

LECTOTYPE: Cortinarius gausapatus J.Favre. Switzerland, Graubünden, Murtaröl d'Aint, near Pass dal Fuorn, alt. 2500 m, among Salix retusa, Triassic calcareous soil, 22.VIII.1949 J. Favre ZA 147b (GK 13281). - Specimen with ca. 20 fruitbodies. Spores $9.0-\underline{10.5}-12.9 \times 5.7-\underline{6.4}-7.0 \mu \mathrm{m}, \mathrm{Q}=1.50-\underline{1.66}-$ $2.05(\mathrm{n}=20)$; shape rather variable from broad to narrow ellipsoid, suprahilar depression occasional; rather weakly verrucose; weakly dextrinoid.

SPECIMEN EXAMINED: Cortinarius gausapatus J.Favre. Switzerland, Graubünden, Val Stabelchod, among Salix herbacea, alt. 2550 m, 9.IX.1942 J. Favre ZA 147a (GK 13280). - Spores similar to the lectotype.

Cortinarius gausapatus was found only from the Swiss Alps in this study. The fruitbodies of the recent collections resembled the description of Favre (1955), having usually a distinctly squamulose or fibrillose pilei and large spores. The spores were ellipsoid to obtusely amygdaloid and rather weakly to rather strongly verrucose. All recent five gausapatus collections had long ITS sequences consisting of partially repetitive joint sequences, differing thus distinctly from all other sequences of this study. The five sequences were identical, except two sequences had the same gap of one base. The Favre's collections yielded only partial sequences, but they were identical with the long ones. Cortinarius gausapatus is closely related to the $C$. inops complex. The ITS sequences of the species differed minimum 11 bases and 5 indels from each other.

OTHER SPECIMENS EXAMINED: SWITZERLAND. Graubünden. Scuol, Val Plavna, alt. 2315 m, near Salix herbacea and S. reticulata, 15.VIII.2017 Kokkonen 262/17*, alt. 2320 m, among S. herbacea, Kokkonen $291 / 17^{*}, 294 / 17^{*}$, alt. $2340 \mathrm{~m}$, among S. reticulata and Dryas, Kokkonen 311/17*. Val Müstair, Costainas, alt. 2555 m, near S. retusa, 11.IX.2018 Kokkonen 831/18*. 
Cortinarius helobius Romagn., Bull. Soc. Nat. Oyonnax 6: 62 (1952) Cortinarius galerinoides Lamoure, Trav. Sci. Parc Natl. Vanoise 8: 133 (1977)

Figure 18

The identification of $C$. helobius Romagn. was based on a C. helobius collection from France (Moënne-Loccoz \& Reumaux 1991) together with the information of the C. helobius collection of Cortinarius Flora Photographica from the boreal zone in Sweden (Brandrud et al. 1994, Lindström et al. 2008, GenBank DQ102686). They had only one different base in ITS sequences and are likely conspecific. Two collections of C. inhonestus (Weinm.) Moënne-Loccoz \& Reumaux (Moënne-Loccoz \& Reumaux 1991) had identical sequences with the French helobius sequence. All four specimens were from lowland habitats near Salix. Cortinarius helobius was not found from the boreal zone in this study and must be there rare. It is probably more common in the temperate zone. According to Romagnesi (1952), it occurs rather commonly in moist places with hygrophilous plants, for example in pits and by ponds.

The type of $C$. galerinoides Lamoure deviated from the French helobius sequences by two bases and two indels in ITS, possibly representing a separate species. However, the difference from the Swedish helobius collection was only one base and two indels. Two collections from the Swiss Alps growing with dwarf Salix had identical sequences with the type, and a Swiss alpine specimen (KK44/19) was genetically between the above-mentioned species. It deviated from C. galerinoides by two indels and from the C. helobius collections 1-2 bases. More collections including the type of $C$. helobius should be examined to clear these species. Cortinarius galerinoides was described from the alpine zone (Lamoure 1977), and the two species may have different habitats. In addition, C. galerinoides was described as paler, warm red brown. According to the limited material of this study, all collections had similar micromorphologies, but the three galerinoides specimens with identical sequences had somewhat narrower spores and the lamellar hyphae were more strongly encrusted. Cortinarius helobius and C. galerinoides are closely related to the $C$. inops complex. They deviated from that complex only by 7 bases and 3 indels minimum, and four of the substitutions were adjacent to each other. Suárez-Santiago et al. (2009) had previously reported the genetic closeness of $C$. helobius to $C$. vernus.

HOLOTYPE: Cortinarius galerinoides Lamoure. France, Savoie, Vanoise, under Col de l'Iseran, alt. 2600 m, Salix herbacea, 19.VIII.1971 D. Lamoure (LY). - Piece of type as a loan. Spores 7.6- $\underline{8.6}-9.5 \times 4.6-$ $\underline{5.1}-5.5 \mu \mathrm{m}, \mathrm{Q}=1.45-\underline{1.68}-1.92(\mathrm{n}=20)$; usually ellipsoid, occasionally subamygdaloid or amygdaloid, suprahilar depression occasional, rarely constricted; rather strongly to strongly verrucose; weakly dextrinoid. Lamellar hyphae strongly encrusted.

SPECIMEN EXAMINED: Cortinarius helobius Romagn. France, Haute-Savoie, Rumilly, a pit, at the base of Salix and stunted Populus, or under Salix, 30.V.1985 and 4.V.1986 leg. P. Moënne-Loccoz, det. J. Melot (Herb. P. Moënne-Loccoz no. 052). - Part of specimen as a loan. Spores 7.8- $\underline{8.6}-9.5 \times 5.0-$ 5.5-5.9 $\mu \mathrm{m}, \mathrm{Q}=1.40-1.55-1.70(\mathrm{n}=20)$; ellipsoid, rarely subamygdaloid or obtusely amygdaloid, suprahilar depression occasional; very strongly verrucose; weakly dextrinoid. Some lamellar hyphae slightly to moderately encrusted.

SPECIMEN EXAMINED: Cortinarius inhonestus (Weinm.) Moënne-Locc. \& Reumaux. France, Haute-Savoie, Alex, gravels of the river Fier, under $\mathrm{Sa}$ lix, 11.VI. 1987 leg. P. Moënne-Loccoz, det. P. Reumaux (Herb. P. Moënne-Loccoz no. 603). - Part of specimen as a loan. Spores $7.2-\underline{8.1}-9.0 \times 4.9-\underline{5.3}-5.9 \mu \mathrm{m}$, $\mathrm{Q}=1.43-\underline{1.53}-1.68(\mathrm{n}=20)$; ellipsoid, rarely subamygdaloid or obtusely amygdaloid, suprahilar depression rare; very strongly verrucose; weakly or rather weakly dextrinoid. Lamellar hyphae moderately encrusted.

SPECIMEN EXAMINED: Cortinarius inhonestus (Weinm.) Moënne-Locc. \& Reumaux. France, Haute-Savoie, Alex, gravels of the river Fier, under Salix, 11.VI. 1987 leg. P. Moënne-Loccoz, det. P. Reumaux (Herb. P. Moënne-Loccoz no. 606). - Part of specimen as a loan. Spores 7.5- $\underline{8.3}-8.9 \times 5.1-$ 5.5-6.0 $\mu \mathrm{m}, \mathrm{Q}=1.44-\underline{1.50}-1.56 \quad(\mathrm{n}=10)$; similar to the previous specimen. Some lamellar hyphae slightly encrusted.

OTHER SPECIMENS EXAMINED: Switzerland. Graubünden. Scuol, Val Plavna, alt. 2315 m, near Salix reticulata, 15.VIII.2017 Kokkonen 296/17*, 310/17*, Val S-Charl, Valbella, alt. 2185 m, near S. reticulata, 26.VIII.2019 Kokkonen 44/19\%. 
Cortinarius hinnuleus Fr. var. minutalis

J.Favre, Ergebn. Wiss. Unters. Schweiz. Natl. Parks 5 (33): 203 (1955)

LECTOTYPE: Cortinarius hinnuleus Fr. var. minutalis J.Favre. Switzerland, Graubünden, between Pass of Murter and Piz Murter, alt. 2600 m, among Salix retusa, Triassic calcareous soil, 1.IX.1953 J. Favre (GK 13292). - Spores 6.8$\mu \mathrm{m}, \mathrm{Q}=1.24-\underline{1.39}-1.60 \quad(\mathrm{n}=20)$; broadly ellipsoid; strongly verrucose; weakly dextrinoid.

Cortinarius hinnuleus var. minutalis was found from an alpine site on a fjeld in Finland, but not from the boreal zone. It grew among Salix reticulata, and near S. glauca, S. herbacea and Betula nana. The fruitbodies were orange brown with red brown lamellae and scarce white veil on stipe. The spores were larger than in the type: $7.8-\underline{8.6}-9.2 \times 5.6-$ $\underline{5.9}-6.3 \mu \mathrm{m}$, with $\mathrm{Q}=1.38-\underline{1.46}-1.58$. The lamellar hyphae were smooth or slightly rough.

OTHER SPECIMEN EXAMINED: FINLAND. Inarin Lappi. Utsjoki, Tsuomasvarri, 26.VIII.2005 Kokkonen 514/05*.

Cortinarius lacustris f. alboanulatus MoënneLocc. \& Reumaux, Atlas des Cortinaires Les Cortinaires Hinnuloides 1: 148 (1997)

ISOTYPE: Cortinarius lacustris f. alboanulatus Moënne-Locc. \& Reumaux. France, Île-de-France, Rambouillet forest, pond of Étang d'Or, 20.X.1987 leg. J. Poirier (Herb. P. Moënne-Loccoz no. 1165). - Part of specimen as a loan. Spores $7.5-\underline{8.8}-10.7 \times 4.5-$ $\underline{5.1}-6.5 \mu \mathrm{m}, \mathrm{Q}=1.63-\underline{1.74}-1.91(\mathrm{n}=20)$; dacryoid to somewhat fusoid, rarely without a suprahilar depression; usually moderately verrucose; moderately dextrinoid. Lamellar hyphae moderately encrusted.

\section{Cortinarius neglectus Carteret, Atlas des Cortinaires 21: 1786 (2013)}

hOLOTYPE: Cortinarius neglectus Carteret. France, Île-de-France, Rambouillet forest, Étang-Neuf, under deciduous trees (Betula, Quercus), soil clay-calcareous, 15.XI.2009 X. Carteret, XC 2009-62 (PC).
- Spores 8.4- $\underline{9.8}-11.2 \times 5.4-\underline{5.8}-6.1 \mu \mathrm{m}, \mathrm{Q}=1.53-$ $\underline{1.69}-1.87(\mathrm{n}=20)$; ellipsoid, rarely subamygdaloid or amygdaloid, suprahilar depression occasional; strongly verrucose, verrucae often larger at apex: rather strongly to strongly dextrinoid. Lamellar hyphae smooth.

Cortinarius perzonatus Reumaux, Atlas des Cortinaires 14: 907 (2004)

HOLOTYPE: Cortinarius perzonatus Reumaux. France, Ardennes, Les Alleux, under hygrophilous trees, 3.X.1998 leg. P. Reumaux, PML 5255 (PC). Spores $7.7-\underline{9.2}-11.1 \times 4.9-\underline{5.7}-6.6 \mu \mathrm{m}, \mathrm{Q}=1.38$ $\underline{1.61}-1.80 \quad(\mathrm{n}=20)$; usually ellipsoid, occasionally amygdaloid, rarely fusoid, suprahilar depression frequent; rather strongly to strongly verrucose, verrucae often larger at apex; moderately to rather strongly dextrinoid. Lamellar hyphae smooth.

Cortinarius rufescentipes Bidaud, Atlas des Cortinaires 11: 575 (2001)

HOLOTYPE: Cortinarius rufescentipes Bidaud. France, Bourgogne-Franche-Comté, environment of Belfort, alt. $350 \mathrm{~m}$, under acidophilous deciduous trees, 6.X.1998 A. Bidaud (no. 5095 in PC). - Spores $6.8-\underline{7.4}-8.4 \times 4.6-\underline{4.9}-5.2 \mu \mathrm{m}, \mathrm{Q}=1.39-\underline{1.51}-$ $1.70(\mathrm{n}=20)$; ordinary or broadly ellipsoid; rather weakly verrucose; weakly to rather strongly dextrinoid. Lamellar hyphae smooth.

Cortinarius sphagnicola Carteret \& Reumaux, Atlas des Cortinaires 14: 908 (2004)

HOLOTYPE: Cortinarius sphagnicola Carteret \& Reumaux. France, Île-de-France, Rambouillet forest, pond of Étang d'Or, under hygrophilous trees, among Sphagnum, 18.IX.1993 leg. P.-A. Moreau, PML 3934 (PC). - Spores rather scarce; 7.0-7.7-9.0 $\times$ 4.6- $5.2-5.7 \mu \mathrm{m}, \mathrm{Q}=1.25-\underline{1.50}-1.73(\mathrm{n}=20)$; ordinary or broadly ellipsoid; weakly to moderately verrucose; weakly dextrinoid. Lamellar hyphae moderately encrusted. 
Cortinarius subcastaneus Bidaud \& Reumaux, Atlas des Cortinaires 10: 515 (2000)

HOLOTYPE: Cortinarius subcastaneus Bidaud \& Reumaux. France, Dordogne, Forest of Born, near a pond, under hygrophilous deciduous trees (Betula, Salix), 27.X.1997 A. Bidaud, no. 5092 (PC). Spores 7.5- $\underline{8.5}-10.2 \times 5.0-\underline{5.5}-5.9 \mu \mathrm{m}, \mathrm{Q}=1.36-$ $\underline{1.55}-1.85(\mathrm{n}=20)$; ellipsoid or occasionally obtusely amygdaloid, suprahilar depression occasional; very strongly verrucose, verrucae large; rather strongly dextrinoid. Lamellar hyphae smooth.

Cortinarius tenebricus J.Favre, Ergebn.

Wiss. Unters. Schweiz. Natl. Parks 5 (33): 204 (1955)

LECTOTYPE: Cortinarius tenebricus J.Favre. Switzerland, Graubünden, National Park, Val Plavna, between the cottage and Pass of Botsch, alt. ca. $2200 \mathrm{~m}$, Triassic calcareous soil, among Salix reticulata and S. retusa, 15.VIII.1941 J. Favre ZA 168a (GK 13514). Specimen with ca. 10 fruitbodies. Spores 6.6- $\underline{7.8}-$ $9.4 \times 4.8-\underline{5.2}-5.7 \mu \mathrm{m}, \mathrm{Q}=1.32-\underline{1.50}-1.78(\mathrm{n}=20)$; ellipsoid, sometimes a slight suprahilar depression; rather strongly to strongly verrucose; rather strongly dextrinoid. Cheilocystidia not observed.

\section{Phylogeny}

The ML phylogenetic trees are presented in Figures 19 and 20. The species complexes were similarly formed by ITS and RPB2 analyses. In the RPB2 tree, the species complexes were wider apart from each other compared with the ITS tree. Also, the distances between close species were often longer in RPB2 analyses, but there occurred also significant variation. Within some complexes, the species or specimens were differently related with each other in ITS and RPB2 trees, complicating the phylogenetic interpretation. Further, the ancestral nodes of the ITS tree had very low bootstrap values. In the concatenated tree of ITS and RPB2 sequences, the com- plexes included the sames clades as the separate trees and the new species were even more strongly supported by bootstrap values. The amount of intraspecific variation varied somewhat among the species. The intraspecific variation was more often higher among RPB2 sequences than among ITS sequences. The Bayesian trees were similar to the ML trees. Highly supported branches are shown in the ML trees. More DNA regions would be required to see the evolutionary history of all species.

\section{Discussion}

The diversity of small Telamonia in boreal lowland Salix thickets is high. Altogether 23 species were recognized in Finland. Most of them could be named and four species are described as new. The taxonomy was based on DNA analyses of the ITS region and less of the RPB2 region together with extensive morphological examinations. A large genetic and morphological variation emerged. The differences between species or clades were often small, which is why the species limits remained sometimes obscure. Nearly all species were involved in species complexes.

Ample material from some boreal sites allowed site-specific morphological and genetic comparisons to be made, which eliminated the effects of environment and geographical distance on variation. These comparisons were used to delimit species in unclear cases. Groups of specimens differing only by two or few bases in ITS sequences and having very similar morphologies were interpreted as separate species especially when they grew at the same sites without genetic intermediates, differed there morphologically at least somehow, and were separated by RPB2 sequences. The results indicate that the ITS differences of only two bases are possible between Telamonia species from distant locations. The ITS variation of only one base was seen as intraspecific or the interpretation was left open due to the insufficient data. Also, the occurrence of deletions and/or insertions withour base changes was regarded as intraspecific. Some specimens deviating by one base, or once by two bases, from each other in ITS sequences had identical RPB2 sequences, which was regarded as a 


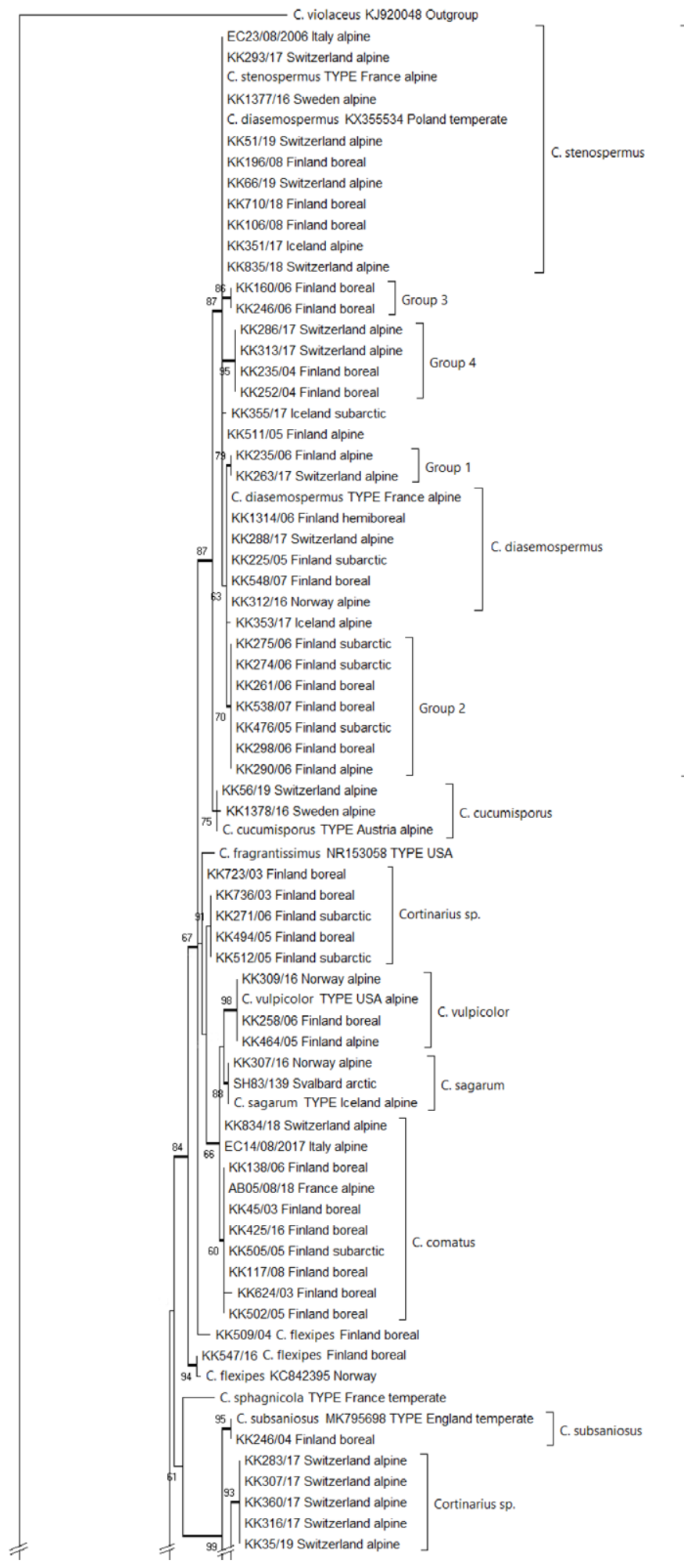

Fig. 19. (five parts) A maximum likelihood tree of ITS sequences. ML bootstrap values $\geq 50$ are given at nodes. Log likelihood -4018.86. Branches with Bayesian posterior probabilities $\geq 0.95$ have thick lines. 


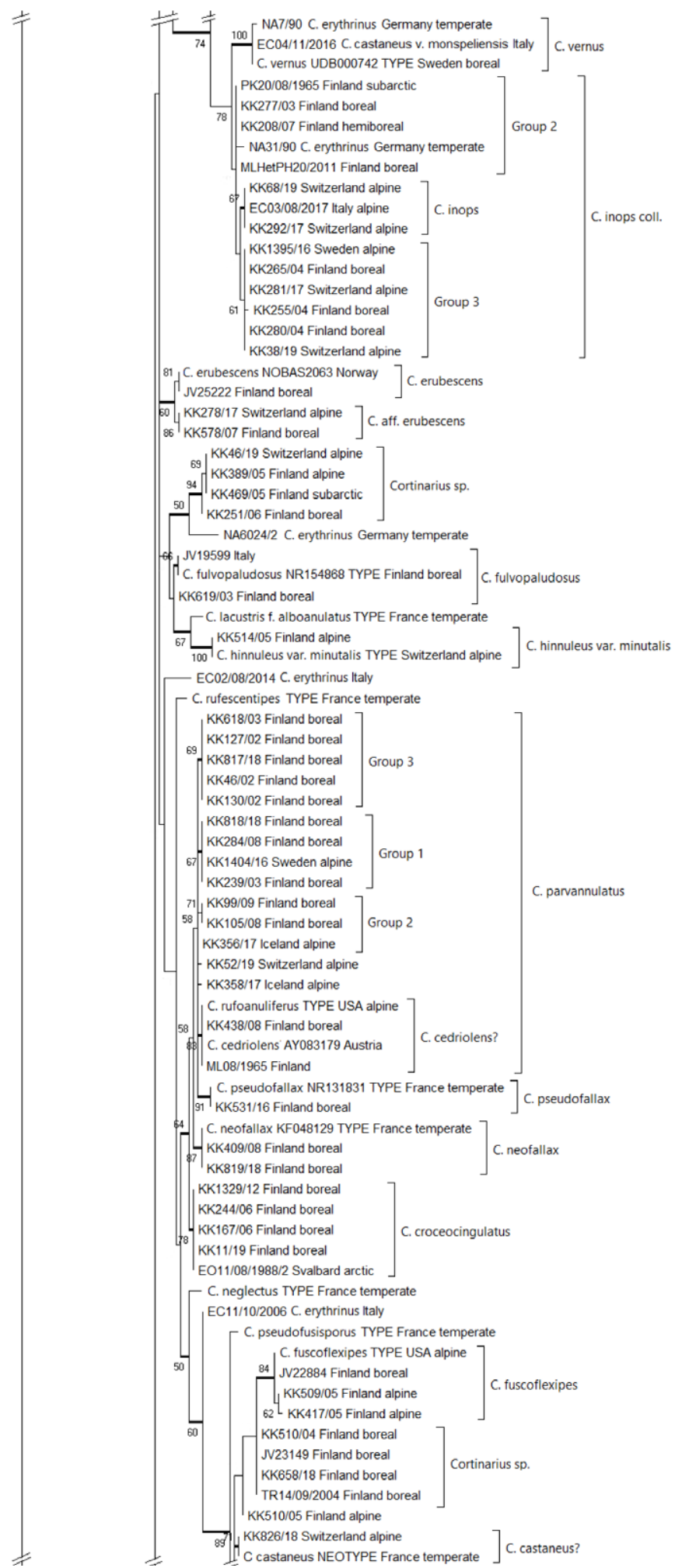

Fig. 19, part 3 


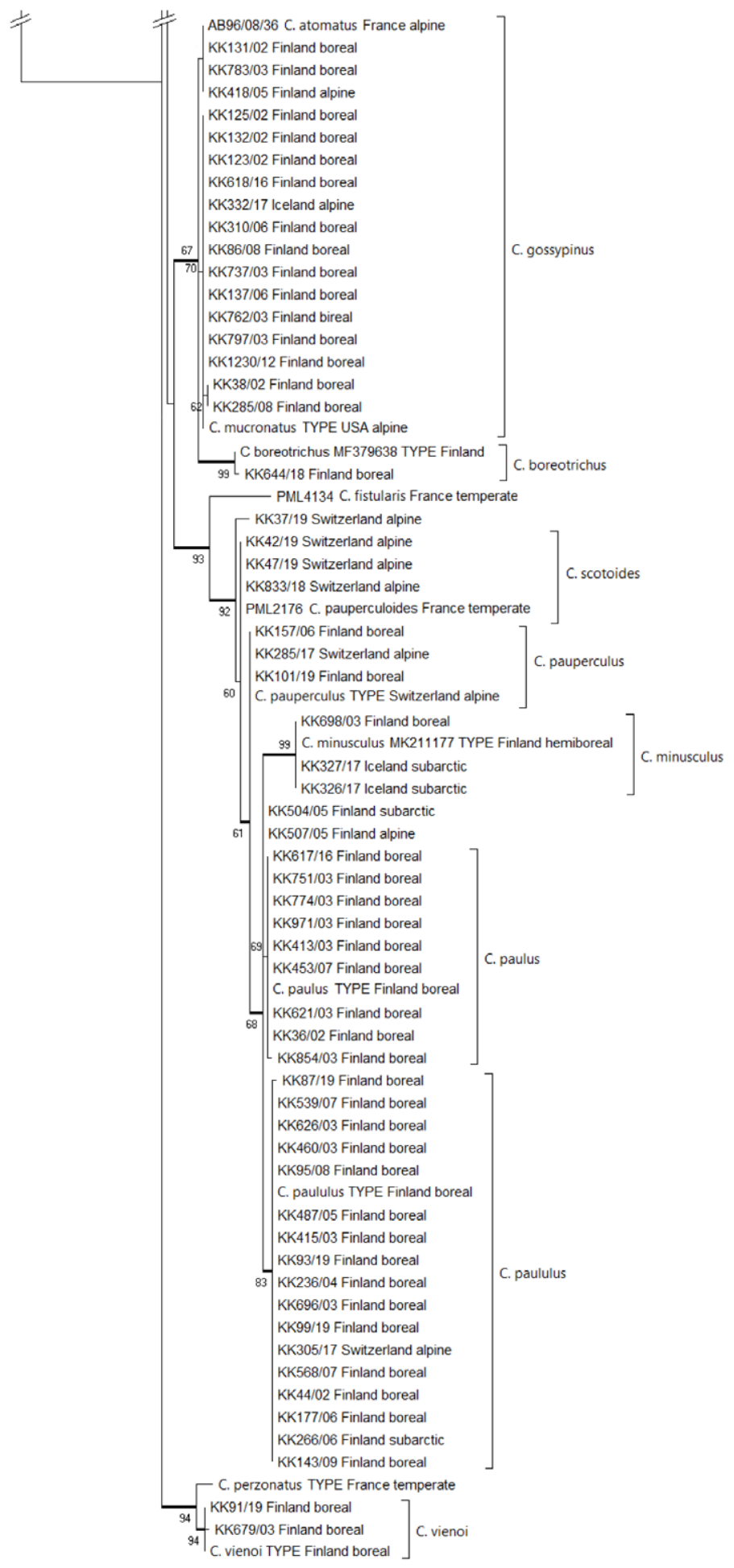


clear sign of conspecifity. The results of ITS and RPB2 analyses were not fully concordant, and RPB2 analyses helped to delimit species. Inclusion of some other regions could improve the resolution still. In the study of Frøslev et al. (2005), both RPB1 and RPB2 improved the resolution of Cortinarius species. According to Garnica et al. (2016), the threshold values of the ITS region for species limitation vary within the Cortinarius genus. No fully cryptic species were identified in this study, although the possibility for cryptic species was observed especially within the $C$. inops complex. For the still obscure cases, more material should be examined. Cryptic Cortinarius species have been reported, but rarely (e.g. Frøslev et al. 2007, Liimatainen et al. 2015, 2017).

The mycofloras of small Telamonia did not differ remarkably between the boreal and alpine zones. Eighteen of the 23 species were found both with the boreal shrubby Salix species and with arctic-alpine dwarf Salix. The remaining five species are yet to be found from the arctic-alpine zone, since this study concentrated on boreal fungi. Three of these five species are described here as new, and they seem to be uncommon. One new species, C. paululus, was rather common and it was found also from the Alps. One species solely from the boreal zone remained undetermined. It was close to difficult species complexes including C.flexipes. The mycofloras of inland shores and seashores differed somewhat. Two species from the seashores were found from the alpine zone, but not from boreal inland thickets. Considering the climate gradient among high alpine, low alpine, subarctic and boreal environments, the occurrence of many common species is not very surprising. Furthermore, the arctic-alpine dwarf and low shrub Salix species are closely related to the boreal taller shrubs. Their division into separate subgenera is not supported by molecular studies (e.g. Chen et al. 2010). It may turn out that also temperate and alpine zones have many common Cortinarius species. Five such species were detected with the scarce temperate material of this study. On the other hand, some arctic or high-alpine species do not likely survive in lower altitudes or milder climates. Among the material of this study, at least six species were found only in the arctic - high-alpine zones, when the number of species within some complexes remained open.

The sequencing of type specimens was impor- tant for the identifications, especially regarding several alpine types of Favre. He was the first to survey thoroughly alpine fungi growing with Salix (Brunner et al. 2017). Most species had wide geographical distributions in this study. A species occurring in Fennoscandia could occur in the Alps, Iceland, or North America. Only few species were found in one country. Cortinarius species have appeared widely distributed in the northern hemisphere in previous works (e.g. Garnica et al. 2009, Harrower et al. 2011, Niskanen et al. 2012a, 2016, Cripps et al. 2015, Liimatainen et al. 2015, 2017, Brandrud et al. 2018). The morphological features varied much within species. Especially the habitus varied among locations or environments. For example, fungi growing on sand or with dwarf Salix were usually smaller than fungi on boreal paludified or muddy shores. The size of fruitbodies, and the width and shape of spores were found as most useful to separate sibling species growing at the same sites. The veil colour was not always constant but varied from white to yellow brown within some species.

The sibling species within the complexes mostly occurred in the same regions. More species will likely be recognized in these complexes from different regions and hosts. Since this study focused on shrubby and dwarf Salix, it remained obscure to which extent the species grow with Salix caprea and other large tree species. At least some species were connected also with other trees: C. fuscoflexipes likely with $S$. caprea, $C$. decipiens likely with Alnus or Betula, C. saniosus with Alnus, and the C. castaneus neotype species and $C$. scotoides with temperate Populus (Moënne-Loccoz \& Reumaux 1990a, C. pauperculoides ad int. in Bidaud et al. 2012). Populus as a close genus, as well as the often co-occurring Alnus and Betula are the most likely genera to share Telamonia species with Salix. Most Cortinarius species have been reported to grow only with one or few host trees or genera, or either with deciduous or coniferous trees (e.g. Frøslev et al. 2007, Garnica et al. 2009). The sibling species in this study appeared to have sometimes hosts from different genera, like C. vienoi and C. perzonatus, C. rufostriatus in the $C$. casimiri complex, and an anonymous species in the C. decipiens complex. The sibling species were probably not connected with different, closely related $\mathrm{Sa}$ lix species in the same habitat. In the study of Ryberg 


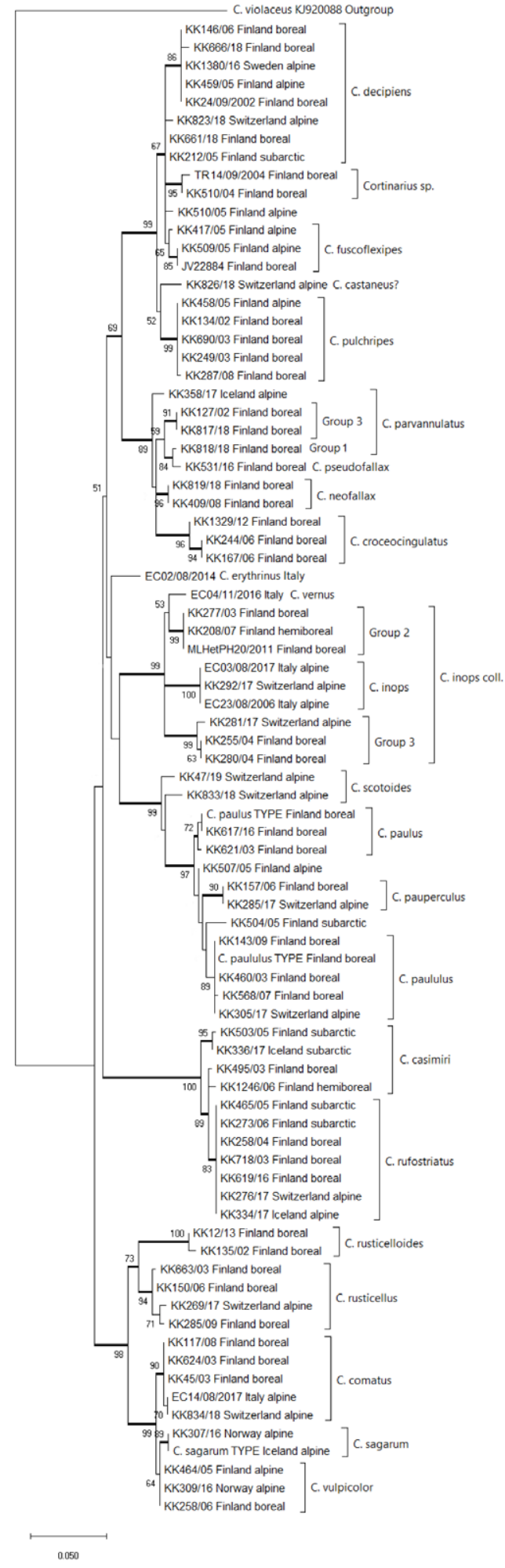

Fig. 20. A maximum likelihood tree of RPB2 sequences. $M L$ bootstrap values $\geq 50$ are given at nodes. Log likelihood -3257.56. Branches with Bayesian posterior probabilities $\geq 0.95$ have thick lines.

et al. (2011), Salix herbacea and S. polaris had similar ectomycorrhizal communities in the same alpine locality. The boreal Salix thickets of this study mainly consisted of S. phylicifolia and S. myrsinifolia, which commonly hybridize with each other. A site with $S$. phylicifolia and S. myrsinifolia as the only tree species included the sibling species $C$. rusticellus and C. rusticelloides. The sibling species $C$. paulus and $C$. paululus also occurred at two same sites dominated by those Salix species. One possible explanation for the co-occurrence of the sibling species is a previous allopatric speciation in glacial refugia, for the same or different hosts. Salix myrsinifolia and S. phylicifolia may have also been allopatric. The speciation of Cortinarius likely follows the speciation of hosts. The presumed rapid diversification of boreo-arctic Salix species during Pleistocene (Lauron-Moreau et al. 2015) is probably connected with the confusing species complexes of their Telamonia. The low divergence of ITS sequences within Cortinarius has been proposed to result from on-going speciation (Peintner 2008). Intraspecific or intragenomic polymorphism has occurred commonly within some Cortinarius species or sections (e.g. Frøslev et al. 2007, Niskanen et al. 2009, Suárez-Santiago et al. 2009). Intragenomic polymorphism appearing as ambiguous bases was rather common in this study, but the role of hybridization among species remained obscure. 


\section{Acknowledgements}

The curator Bart Buyck is thanked for hospitality while visiting PC. André Bidaud is thanked for lending specimens from his private herbarium and Herbarium P. Moënne-Loccoz as well as sending a photo. Thanks are extended to the curators of the following herbaria for sending loans: G, IB, LY, REG and S.

The curator Seppo Huhtinen is thanked for providing facilities in TUR and arranging some loans. Ursula Peintner is thanked for sharing three type sequences, her alpine data, and information of C. rusticellus. Tuula Niskanen and Kare Liimatainen are thanked for information of $\mathrm{C}$. dumetorum. Emanuele Campo is thanked for the permission to publish his photo. Two anonymous reviewers are thanked for the comments. I am grateful to my parents for support.

\section{References}

Arnold, N. 1993: Morphologisch-anatomische und chemische Untersuchungen an der Undergattung Telamonia (Cortinarius, Agaricales). Libri Botanici, Band 7. IHW-Verlag: Eching.

Bendiksen, E., Brandrud, T.E., Bendiksen, K. \& Lindström, H. 1993: A study of the Cortinarius helobius -complex, with special emphasis on arctic-alpine material. Arctic and Alpine Mycology 150: 3-15.

Bidaud, A., Carteret, X., Eyssartier, G., Moënne-Loccoz, P. \& Reumaux, P. 2004: Atlas des Cortinaires, Pars XIV. Art Print: Lyon.

Bidaud, A., Carteret, X., Reumaux, P. \& Moënne-Loccoz, P. 2012: Atlas des Cortinaires, Pars XX. Éditions FMDS: Lomazzo.

Bidaud, A., Henry, R., Moënne-Loccoz, P. \& Reumaux, P. 1991: Atlas des Cortinaires, Pars III. Valpress: Annecy-Seynod.

Bidaud, A., Moënne-Loccoz, P. \& Reumaux, P. 2001: Atlas des Cortinaires, Pars XI. Art Print: Lyon.

Bidaud, A., Moënne-Loccoz, P., Reumaux, P. \& Carteret, X . 2010: Atlas des Cortinaires, Pars XIX. Éditions FMDS: Lomazzo.

Bjorbaekmo, M.F., Carlsen, T., Brysting, A., Vralstad, T., Høiland, K., Ugland, K.I., Geml, J., Schumacher, T. \& Kauserud, H. 2010: High diversity of root associated fungi in both alpine and arctic Dryas octopetala. BMC Plant Biology 10: 244.
Borchsenius, F. 2009: FastGap 1.2. Department of Biosciences, Aarhus University, Denmark. Published online at http:// www.aubot.dk/FastGap_home_htm.

Brandrud, T.E., Bendiksen, E. \& Dima, B. 2015: Some new and little known telamonioid Cortinarius species from Norway. Agarica 36: 11-42.

Brandrud, T.E., Lindström, H., Marklund, H., Melot, J. \& Muskos, S. 1994: Cortinarius Flora Photographica, Del 3. Cortinarius HB: Matfors.

Brandrud, T.E., Lindström, H., Marklund, H., Melot, J. \& Muskos, S. 1998: Cortinarius Flora Photographica, Vol. 4. Cortinarius HB: Matfors.

Brandrud, T.E., Lindström, H., Marklund, H., Melot, J. \& Muskos, S. 2012: Cortinarius Flora Photographica, Del 5. Cortinarius HB: Matfors.

Brandrud, T.E., Schmidt-Stohn, G., Liimatainen, K. et al. 2018: Cortinarius sect. Riederi: taxonomy and phylogeny of the new section with European and North American distribution. Mycological Progress 17(12): 1323-1354.

Brunner, I., Frey, B., Hartmann, M., Zimmermann, S., Graf, F., Suz, L.M., Niskanen, T., Bidartondo, M.I. \& Senn-Irlet B. 2017: Ecology of Alpine Macrofungi - Combining Historical with Recent Data. Frontiers in Microbiology 8: 2066.

Chen, J.H., Sun, H., Wen, J. \& Yang, Y.P. 2010: Molecular phylogeny of Salix L. (Salicaceae) inferred from three chloroplast datasets and its systematic implications. Taxon 59: 29-37.

Cripps, C.L., Liimatainen, K., Niskanen, T., Dima, B., Bishop, R.F. \& Ammirati, J.F. 2015: Intercontinental distributions of species of Cortinarius, subgenus Phlegmacium, associated with Populus in western North America. Botany 93: 711-721.

Dima, B., Lindström, H., Liimatainen, K., Olson, Å., Soop, K., Kytövuori, I., Dahlberg, A. \& Niskanen, T. 2016: Typification of Friesian names in Cortinarius sections Anomali, Spilomei, and Bolares, and description of two new species from northern Europe. Mycological Progress 15: 903-919.

Edler, D., Klein, J., Antonelli, A., Silvestro, D. 2019: raxmIGUI 2.0 beta: a graphical interface and toolkit for phylogenetic analyses using RAxML. bioRxiv, doi: https://doi.org/10.1101/800912.

Esteve-Raventós, F., Niskanen, T., Platas, G., Liimatainen, K. \& Ortega, A. 2014: Cortinarius pseudofallax (Cortinariaceae, Agaricales), the first records from the Iberian Peninsula and Fennoscandia, and taxonomic notes on the C. parvannulatus / cedriolens group. Mycological Progress 13: 393-398. 
Favre, J. 1948: Les associations fongiques des hauts-marais jurassiens et de quelques régions voisines. Beiträge zur Kryptogamenflora der Schweiz 10(3): 1-228.

Favre, J. 1955: Les champignons supérieurs de la zone alpine du parc national Suisse. Ergebnisse der wissenschaftlichen Untersuchungen des schweizerischen Nationalparks 33: 1-212.

Favre, J. 1960: Catalogue descriptive des champignons supérieurs de la zone subalpine du parc national Suisse. Ergebnisse der wissenschaftlichen Untersuchungen des schweizerischen Nationalparks 42: 1-610.

Fries, E.M. 1821: Systema mycologicum 1: 1-520. Lundae.

Fries, E.M. 1838: Epicrisis Systematis Mycologici. Upsaliae.

Frøslev, T.G., Jeppesen, T.S., Læssøe, T. \& Kjøller, R. 2007: Molecular phylogenetics and delimitation of species in Cortinarius section Calochroi (Basidiomycota, Agaricales) in Europe. Molecular Phylogenetics and Evolution 44: 217-227.

Frøslev, T.G., Matheny, P.B. \& Hibbett, D.S. 2005: Lower level relationships in the mushroom genus Cortinarius (Basidiomycota, Agaricales): A comparison of RPB1, RPB2, and ITS phylogenies. Molecular Phylogenetics and Evolution 37: 602-618.

Fujiyoshi, M., Yoshitake, S., Watanabe, K., Murota, K., Tsuchiya, Y., Uchida, M. \& Nakatsubo, T. 2011: Successional changes in ectomycorrhizal fungi associated with the polar willow Salix polaris in a deglaciated area in the High Arctic, Svalbard. Polar Biology 34(5): 667-673.

Gardes, M. \& Bruns, T.D. 1993: ITS primers with enhanced specificity for basidiomycetes - application to the identification of mycorrhizae and rusts. Molecular Ecology 2: 113-118.

Garnica, S., Schön, M.E., Abarenkov, K. et al. 2016: Determining threshold values for barcoding fungi: lessons from Cortinarius (Basidiomycota), a highly diverse and widespread ectomycorrhizal genus. FEMS Microbiology Ecology 92(4) fiw045: 1-16.

Garnica, S., Weiß, M., Oertel, B., Ammirati, J. \& Oberwinkler, F. 2009: Phylogenetic relationships in Cortinarius, section Calochroi, inferred from nuclear DNA sequences. BMC Evolutionary Biology 9: 1.

Geml, J., Timling, I., Robinson, C.H., Lennon, N., Nusbaum, H.C., Brochmann, C., Noordeloos, M.E. \& Taylor, D.L. 2012: An arctic community of symbiotic fungi assembled by long-distance dispersers: phylogenetic diversity of ectomycorrhizal basidiomycetes in Svalbard based on soil and sporocarp DNA. Journal of Biogeography 39(1): 74-88.
Harrower, E., Ammirati, J.F., Cappuccino, A.A., Ceska, O., Kranabetter, J.M., Kroeger, P., Lim, S., Taylor, T. \& Berbee, M.L. 2011: Cortinarius species diversity in British Columbia and molecular phylogenetic comparison with European specimen sequences. Botany 89: 799-810.

Harrower, E., Bougher, N.L., Henkel, T.W., Horak, E. \& Matheny, P.B. (2015) Long-distance dispersal and speciation of Australasian and American species of Cortinarius sect. Cortinarius. Mycologia 107(4): 697-709.

Henry, R. 1957: Nouvelle contribution a l'étude de cortinaires rares ou nouveaux, principalement rencontrés en FrancheComté. Bulletin trimestriel de la Société mycologique de France 73: 18-76.

Horak, E. 1987: Revision der von J. FAVRE (1955) aus der Region des Schweizer Nationalparks beschriebenen alpinen Arten von Cortinarius subgen. Telamonia (Agaricales). Candollea 42: 771-803.

Hyde, K.D., Dong, Y., Sheng, J. et al. 2020: Fungal diversity notes 1151-1276: taxonomic and phylogenetic contributions on genera and species of fungal taxa. Fungal Diversity 100: 5-277.

Hyde, K.D., Tennakoon, D.S., Jeewon, R. et al. 2019: Fungal diversity notes 1036-1150: taxonomic and phylogenetic contributions on genera and species of fungal taxa. Fungal Diversity 96(1): 1-242.

Ihrmark, K., Bödeker, I.T., Cruz-Martinez, K., Friberg, H., Kubartova, A., Schenck, J., Strid, Y., Stenlid, J., Brandström-Durling, M., Clemmensen, K.E. \& Lindahl, B.D. 2012: New primers to amplify the fungal ITS2 region - evaluation by 454-sequencing of artificial and natural communities. FEMS Microbiology Ecology 82(3): 666-677.

Katoh, S. 2013: MAFFT multiple sequence alignment software version 7: improvements in performance and usability. Molecular Biology and Evolution 30: 772-780.

Kokkonen, K. \& Vauras, J. 2012: Eleven new boreal species of Inocybe with nodulose spores. Mycological Progress 11(1): 299-341.

Kumar, S., Stecher, G., Li, M., Knyaz, C. \& Tamura, K. 2018: MEGA X: Molecular Evolutionary Genetics Analysis across computing platforms. Molecular Biology and Evolution 35: 1547-1549.

Küppers, H. 1999: Du'Monts Farbenatlas, 7th edn. DuMont Buchverlag: Köln. 
Lamoure, D. 1977: Agaricales de la zone alpine genre Cortinarius Fr. sous-genre Telamonia (Fr.) Loud. première partie. Extrait de Travaux scientifiques du parc national de la Vanoise VIII: 115-146.

Lamoure, D. 1978: Agaricales de la zone alpine genre Cortinarius Fr. sous-genre Telamonia (Fr.) Loud. suite (I). Extrait de Travaux scientifiques du parc national de la Vanoise IX: 77-101.

Lamoure, D. 1987: Agaricales de la zone alpine genus Cortinarius Fr., subgenus Telamonia (Fr.) Loud. part III. In: Laursen, G.A., Ammirati, J.F. \& Readhead, S.A. (eds). Arctic and Alpine Mycology II, Environmental science research, volume 34, 255-259. Plenum press, New York.

Larsson, A. 2014: AliView: a fast and lightweight alignment viewer and editor for large data. Bioinformatics 30(22): 3276-3278.

Lauron-Moreau, A., Pitre, F.E., Argus, G.W., Labrecque, M. \& Brouillet, L. 2015: Phylogenetic Relationships of American Willows (Salix L., Salicaceae). PLoS ONE 10(4): e0121965.

Li, G.J., Hyde, K.D., Zhao, R.L. et al. 2016: Fungal diversity notes 235-366: taxonomic and phylogenetic contributions to fungal taxa. Fungal Diversity 78(1): 1-237.

Liimatainen, K. 2017: Nomenclatural novelties. Index Fungorum 344 (1).

Liimatainen, K., Carteret, X., Dima, B., Kytövuori, I., Bidaud, A., Reumaux, P., Niskanen, T., Ammirati, J.F. \& Bellanger, J.M. 2017: Cortinarius section Bicolores and section Saturnini (Basidiomycota, Agaricales), a morphogenetic overview of European and North American species. Persoonia 39: 175-200.

Liimatainen, K., Niskanen, T., Ammirati, J.F., Kytövuori, I. \& Dima, B. 2015: Cortinarius, subgenus Telamonia, section Disjungendi, cryptic species in North America and Europe. Mycological Progress 14: 1016.

Liimatainen, K., Niskanen, T., Dima, B., Kytövuori, I., Ammirati, J.F. \& Frøslev, T.G. 2014: The largest type study of Agaricales species to date: bringing identification and nomenclature of Phlegmacium (Cortinarius) into the DNA era. Persoonia 33: 98-140.

Lindström, H., Bendiksen, E., Bendiksen, K. \& Larsson, E. 2008: Studies of the Cortinarius saniosus (Fr.:Fr.) Fr. complex and a new closely related species, C. aureovelatus (Basidiomycota, Agaricales). Sommerfeltia 31: 139-159.
Liu, Y.J., Wheten, S. \& Hall, B.D. 2000: Phylogenetic Relationships among Ascomycetes: evidence from an RNA Polymerase II Subunit. Molecular Biology and Evolution 16(12): 1799-1808.

Melot, J. 1995: Le genre Cortinarius en Islande. II. Acta Botanica Islandica 12: 69-94.

Moënne-Loccoz, P. \& Reumaux, P. 1990a: Atlas des Cortinaires, Pars I. Valpress: Annecy-Seynod.

Moënne-Loccoz, P. \& Reumaux, P. (1990b): Atlas des Cortinaires, Pars II. Valpress: Annecy-Seynod.

Moser, M. 1967: Kleine Kryptogamenflora von Mitteleuropa Die Blätter- und Baupilze (Agaricales und Gasteromycetes), Ilb/2: 1-443. G. Fischer: Jena.

Moser, M. 1968: Neue oder kritische Cortinarius-Arten aus der Untergattung Telamonia (Fr.) Loud. Nova Hedwigia 14(2-4): 483-518.

Moser, M. 1983: Notizen zu einigen Cortinarien aus der Untergattung Telamonia. Mycologia Helvetica 1: 1-16.

Moser, M. 1993: Studies on North Americal Cortinarii. III. The Cortinarius flora of dwarf and shrubby Salix associations in the alpine zone of the Windriver Mountains, Wyoming, USA. Sydowia 45(2): 275-306.

Moser, M. \& McKnight, K.H. 1987: Fungi (Agaricales, Russulales) from the alpine zone of Yellowstone national park and the Beartooth mountains with special emphasis on Cortinarius. In: Laursen, G.A., Ammirati, J.F. \& Readhead, S.A. (eds). Arctic and Alpine Mycology II, Environmental science research, volume 34, 299-317. Plenum press, New York.

Mühlmann, O., Bacher, M. \& Peintner, U. 2008: Polygonum viviparum mycobionts on an alpine primary successional glacier forefront. Mycorrhiza 18(2): 87-95.

Mühlmann, O. \& Peintner, U. 2008: Ectomycorrhiza of Kobresia myosuroides at a primary successional glacier forefront. Mycorrhiza 18(6-7): 355-362.

Niskanen, T. 2008: Cortinarius subgenus Telamonia p.p. in North Europe. Ph.D. diss. Publications in Botany from the University of Helsinki N:o 37, Helsinki.

Niskanen, T., Kytövuori, I. \& Liimatainen, K. 2009: Cortinarius sect. Brunnei (Basidiomycota, Agaricales) in North Europe. Mycological Research 113: 182-206.

Niskanen, T., Kytövuori, I. \& Liimatainen, K. 2011: Cortinarius sect. Armillati in northern Europe. Mycologia 103(5): 1080-1101. 
Niskanen, T., Kytövuori, I., Liimatainen, K. \& Lindström, H. 2013: The species of Cortinarius, section Bovini, associated with conifers in northern Europe. Mycologia 105(4): 977-993.

Niskanen, T., Kytövuori, I., Liimatainen, K., Lindström, H., Dentinger, B.T.M. \& Ammirati, J.F. 2016: Cortinarius subgenus Callistei in North America and Europe - type studies, diversity, and distribution of species. Mycologia 108(5): 1018-1027.

Niskanen, T., Liimatainen, K., Kytövuori, I. \& Ammirati, J.F. 2012a: New Cortinarius species from conifer dominated forests of North America and Europe. Botany 90: 743-754.

Niskanen, T., Liimatainen, K., Kytövuori, I. \& Lindström, H. 2012b: Subgen. Telamonia (Fr.) Trog. In: Knudsen, H. \& Vesterholt, J. (eds). Funga Nordica, Vol. 2, Agaricoid, boletoid, clavarioid, cyphelloid and gasteroid genera, 826-885. Nordsvamp, Copenhagen.

Oberkofler, I. \& Peintner, U. 2008: Detection of soil fungal communities in an alpine primary successional habitat: Does pooling of DNA extracts affect investigations? Annals of Microbiology 58(4): 585-595.

Peintner, U. 2008: Cortinarius alpinus as an example for morphological and phylogenetic species concepts in ectomycorrhizal fungi. Sommerfeltia 31: 161-177.

Peintner, U., Moser, M.M., Thomas, K.A. \& Manimohan, P. 2003: First records of ectomycorrhizal Cortinarius species (Agaricales, Basidiomycetes) from tropical India and their phylogenetic position based on rDNA ITS sequences. Mycological Research 107(4): 485-494.

Romagnesi, H. 1952: Deux nouveaux Cortinaires du sous-genre Hydrocybe. Bulletin de la Société des naturalistes d'Oyonnax 6: 59-63.

Ronquist, F., Huelsenbeck, J.P. 2003: MrBayes 3: Bayesian phylogenetic inference under mixed models. Bioinformatics 19: 1572-1574.

Ryberg, M., Andreasen, M. \& Björk, R.G. 2011: Weak habitat specificity in ectomycorrhizal communities associated with Salix herbacea and Salix polaris in alpine tundra. Mycorrhiza 21: 289-296.

Stamatakis, A. 2014: RAxML. Version 8: A tool for Phylogenetic Analysis and Post-Analysis of Large Phylogenies. Bioinformatics 30(9): 1312-1313.
Suárez-Santiago, V.N., Ortega, A., Peintner, U. \& LópezFlores, I. 2009: Study on Cortinarius subgenus Telamonia section Hydrocybe in Europe, with especial emphasis on Mediterranean taxa. Mycological Research 113: 1070-1090.

Suz, L.M., Barsoum, N., Benham, S. et al. 2014: Environmental drivers of ectomycorrhizal communities in Europe's temperate oak forests. Molecular Ecology 23(22): 5628-5644.

Timling, I., Dahlberg, A., Walker, D.A., Gardes, M., Charcosset, J.Y., Welker, J.M. \& Taylor, D.L. 2012: Distribution and drivers of ectomycorrhizal fungal communities across the North American Arctic. Ecosphere 3(11): 111.

Timling, I., Walker, D.A., Nusbaum, C., Lennon, N.J. \& Taylor, D.L. 2014: Rich and cold: diversity, distribution and drivers of fungal communities in patterned-ground ecosystems of the North American Arctic. Molecular Ecology 23(13): 3258-3272.

Velenovský, J. 1921: České Houby 3, 425-632. České Botanické Společnosti: Prague.

White, T.J., Bruns, T.D., Lee, S. \& Taylor, J. 1990: Amplification and direct sequencing of fungal ribosomal RNA genes for phytogenetics. In: Innis, M.A., Gelfand, D.H., Sninsky, J.J. $\&$ White, T.J. (eds). PCR protocols: a guide to methods and applications, 315-322. Academic, San Diego. 